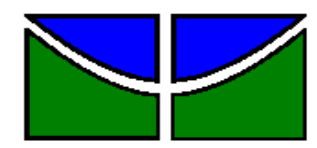

UNIVERSIDADE DE BRASÍLIA - UNB

FACULDADE DE ECONOMIA, ADMINISTRAÇÃO, CONTABILIDADE E CIÊNCIA DA INFORMAÇÃO E DOCUMENTAÇÃO

CURSO DE ESPECIALIZAÇÃ̃O EM GESTÃO JUDICIÁRIA

\title{
A Informatização do Processo Judicial e seus reflexos no Superior Tribunal de Justiça
}

Erickson Brener de Carvalho Cintra 


\section{A Informatização do Processo Judicial e seus reflexos no Superior Tribunal de Justiça}

Projeto de monografia apresentado ao Departamento de Administração da Faculdade de Economia, Administração, Contabilidade e Ciência da Informação e Documentação, da Universidade de Brasília, como requisito parcial à obtenção do grau de Especialista em Gestão Judiciária.

Orientadora: Prof. a Dr. ${ }^{a}$ Sueli Angelica do Amaral 
A minha querida esposa Daniela pelo seu incondicional amor, dedicação e compreensão. 
Agradeço à minha Orientadora, Prof. ${ }^{\text {a }}$ Dr. ${ }^{\text {a }}$ Sueli Angélica do Amaral, pela dedicação e paciência; à minha Chefe e Coordenadora, Dr. ${ }^{a}$ Vanilde S. M. Trigo de Loureiro por sua compreensão e amizade; à Coordenadoria de Recursos Humanos do STJ, que viabilizou o curso de Especialização em Gestão Judiciária; aos meus Professores e Colegas pelo grande aprendizado que me proporcionaram. 
O futuro não pode ser previsto, mas pode ser inventado. É a nossa habilidade de inventar o futuro que nos dá esperança para fazer de nós o que somos.

Dennis Gabor (1900-1979)

Prêmio Nobel de Física em 1971 pela criação e desenvolvimento do método holográfico, precursor da "realidade virtual". 


\section{RESUMO}

CINTRA, Erickson Brener de Carvalho. A Informatização do Processo Judicial e seus reflexos no Poder Judiciário, no Superior Tribunal de Justiça e na Sociedade Brasileira. Monografia de conclusão de especialização em Gestão Judiciária. 138 f. Universidade de Brasília - UNB. Faculdade de Economia, Administração, Contabilidade e Ciência da Informação e Documentação - FACE. Brasília, 2009.

Pesquisa realizada sobre a informatização do processo judicial, por meio da qual busca compreender o fenômeno, através da análise histórica do processo e da informação, do conceito de informatização do processo e da análise da legislação pátria sobre os temas. No trabalho são compilados os requisitos intrínsecos e extrínsecos necessários à informatização do processo judicial, além de ser verificado o nível de implementação da informatização do processo judicial no STJ. Ao final, são feitas análises com o objetivo de mensurar os benefícios da informatização do processo judicial no STJ sob os aspectos da acessibilidade, celeridade e efetividade processual; bem como o impacto da informatização do processo judicial na sociedade brasileira, tomando-se por base o conceito de inclusão digital.

Palavras-chave: informatização, poder judiciário, processo eletrônico, processo judicial, processo judicial informatizado, processo virtual, Superior Tribunal de Justiça, virtualização. 


\section{LISTA DE FIGURAS}

Figura 1 Posse e Uso - Computador e Internet, por renda ___ 25

Figura 2: Tipo de Conexão para acesso à Internet no Domicílio___ 26

Figura 3: Tipo de Conexão para acesso à Internet no Domicílio, por renda___ 26

Figura 4: Organograma do procedimento de certificação digital____ 73

Figura 5: Processos distribuídos e registrados por Unidade da Federação -2008___ 85

Figura 6: Fundamentos Legais e Normativos para a implementação do sistema de informatização do processo judicial___ 102

Figura 7: Implementação do sistema de informatização do processo judicial____ 103

Figura 8: Características gerais do sistema de informatização do processo judicial____ 103

Figura 9: Características gerais do sistema de informatização do processo judicial (continuação)___ 103

Figura 10: Características gerais do sistema de informatização do processo judicial (continuação) 104

Figura 11: Características gerais do sistema de informatização do processo judicial (continuação) 104

\section{LISTA DE GRÁFICOS}

Gráfico 1: Processos julgados no período de 7/4/1989 a 31/12/2007 13

Gráfico 2: Serviços de Governo Eletrônico utilizados em 2007 30

Gráfico 3: Serviços de Governo Eletrônico que o cidadão Brasileiro gostaria de utilizar__ 31

Gráfico 4: Tribunais de Justiça que disponibilizam consultas processuais pela internet__ 44

Gráfico 5: Tribunais de Justiça que disponibilizam Diário de Justiça Eletrônico 44

Gráfico 6: Tribunais de Justiça avaliados que disponibilizam o uso da petição eletrônica__45

\section{LISTA DE QUADROS}

Quadro 1: Pesquisa sobre a informatização dos Tribunais de Justiça no Brasil 42 


\section{LISTA DE TABELAS}

Tabela 1: evolução da informática através ao longo do tempo 63

Tabela 2: Processos distribuídos e registrados por Unidade da Federação 85

Tabela 3: distância rodoviária entre Brasília e importantes cidades brasileiras 86

Tabela 4: Indicadores de distribuição de renda e consumo 87 


\section{SUMÁRIO}

1 INTRODUÇÃO _ 10

1.1 Problema e justificativa da pesquisa___ 13

1.2 Objetivos__ 16

1.3 Metodologia ___ 17

2 INFORMAÇÃO E SOCIEDADE DA INFORMAÇÃO__ 18

2.1 Governo Eletrônico___ 28

2.2 Mundo Jurídico e Tecnologia___ 32

3 A INFORMATIZAÇÃO DOS PROCESSOS JUDICIAIS E O PRINCÍPIO DA LEGALIDADE NA ADMINSITRAÇÃO PÚBLICA___ 35

4 O PROCESSO E SUAS MODALIDADES___ 38

4.1 Os Processos Judiciais e Administrativos___ 38

4.2 O Processo Judicial Eletrônico___ 39

5 PROCESSO JUDICIAL E INFORMATIZAÇÃO___ 41

5.1 A informatização do processo judicial antes da Lei n. ${ }^{\circ}$ 11.419/2006___ 41

5.2 Histórico da legislação brasileira no tocante à modernização do processo judicial__ 45

5.3 A Lei . $^{\circ} 11.419$ de 19 de dezembro de 2006

5.3.1 Histórico__ 48

5.3.2 A informatização do processo judicial e a Lei n. ${ }^{\circ} 11.419 / 2006 \_50$

6 INSUMOS TECNOLÓGICOS NECESSÁRIOS À INFORMATIZAÇÃO DO PROCESSO JUDICIAL__ 62

6.1 Hardware__ 62

6.1.1 Computador___ 62

6.1.2 Impressoras___ 65

6.1.3 Digitalizadores___ 66 
6.1.4 Servidores para armazenamento de dados 67

6.1.5 Redes de transmissão de dados 67

6.2 Software 70

6.3 Insumos que dependem da utilização de hardwares e softwares para se efetivarem e a sua implementação no STJ 71

6.3.1 Assinatura Digital 71

6.3.2 Petição Eletrônica 76

6.3.3 Diário de Justiça Eletrônico ou on line 79

7 OS BENEFÍCIOS DECORRENTES DA INFORMATIZAÇÃO DOS PROCESSOS JUDICIAIS NO SUPERIOR TRIBUNAL DE JUSTIÇA_ 81

7.1 Acessibilidade Processual 82

7.2 Celeridade Processual 91

7.3 Efetividade Processual 94

7.4 Outros aspectos relevantes a serem considerados no que se refere à viabilidade de implementação plena do processo eletrônico_ 100

8 O MODELO DE PROCESSO JUDICIAL INFORMATIZADO NOS JUIZADOS ESPECIAIS FEDERAIS DO ESTADO DE SANTA CATARINA 102

9 CONCLUSÃO 106 


\section{INTRODUÇÃO}

Desde a pré-história, o ser humano e seus antecessores, como o homo erectus, já mantinham laços sociais com seus iguais (ROBERTS, 2003). Com o desenvolvimento da linguagem, a comunicação entre os homens se aprimorou. $\mathrm{O}$ aparecimento da agricultura e a domesticação de animais solidificaram os relacionamentos interpessoais, por tais processos exigirem cooperação. Algum tempo depois, surgiram formas primitivas de Estado, constantemente aprimoradas pelo processo de construção-destruição-reconstrução, até chegarmos ao ano de 2009 depois de Cristo.

Uma das conseqüências dos relacionamentos interpessoais é o surgimento de litígios em torno de interesses em comum. Na pré-história e idade antiga, a auto-tutela foi um dos meios mais corriqueiros para a resolução desses conflitos. Na auto-tutela, uma das partes em litígio impõe, pela força, a sua vontade à parte adversa e toma para si o objeto daquele, que pode ser um interesse, um bem material etc.

Com o advento dos primeiros traços de formação dos Estados, surgiram também formas rudimentares de tutela jurisdicional, onde as partes em litígio relatavam o problema a um terceiro que se encarregaria de dar uma solução ao caso. Esse terceiro poderia ser um oráculo (Grécia Antiga), o Imperador (Roma Clássica), o Clero ou o Senhor de Terras (Feudalismo), o Rei (Monarquias Absolutistas), ou até mesmo um órgão estatal criado especificamente com esse fim. Dessa última hipótese se desenvolveu o Poder Judiciário, o qual ganhou força pela voz de Montesquieu, em Do Espírito das Leis, e que, como mister, chamou para si o direito de dizer o direito ou Jurisdição.

Nunes (2003, p. 3) define a Jurisdição Estatal: 


\begin{abstract}
À função de compor litígios, de declarar e realizar o Direito, dá-se o nome de jurisdição (do latim juris dictio, que significa dizer o direito). A jurisdição pode ser vista sobre três enfoques distintos: como poder, enquanto emana da soberania do Estado, que assumiu o monopólio de dirimir os conflitos; como função, por que constitui uma obrigação do estado de prestar a tutela jurisdicional quando chamado; finalmente, como atividade, uma vez que a jurisdição atua através de uma seqüência de atos processuais.
\end{abstract}

No presente, o Poder Judiciário é uma realidade mundial. Se por um lado, regimes anti-democráticos glosam e manipulam sua atuação, nas democracias livres esse tende a se desenvolver e fortalecer para dar a cada cidadão e setor da sociedade o que é seu por direito.

No Brasil, democracia com limitadas restrições às liberdades de expressão e ao exercício da Tutela Jurisdicional pelo Poder Judiciário, esse vem prestando seus serviços cada vez mais à sociedade e seus diversos setores.

A procura crescente do Poder Judiciário tem de um lado, o cidadão e demais pessoas jurídicas de natureza privada, que cada vez mais se conscientizam de seus direitos, do que fazer para conquistá-los ou resgatá-los; e de seus deveres. Do outro lado está o próprio Estado (União), que nas duas últimas décadas tem sido um dos maiores "clientes" dos Tribunais.

A participação da União em processos judiciais é tamanha, que a Justiça Federal ${ }^{1}$ foi criada para solucionar, como regra, os casos em que ela seja parte ou interessada no resultado do processo. Os demais entes da Federação (estados, municípios e Distrito Federal), além de suas autarquias, fundações, sociedades de economia mista e empresas públicas, integram inúmeras lides constantes de processos judiciais em tramitação nas Justiças Estadual e do Distrito Federal.

A utilização cada vez maior do Poder Judiciário, por parte da sociedade e dos entes públicos, tem acarretado um aumento em proporções geométricas no volume de processos em tramitação e, conseqüientemente, no número de litígios a serem solucionados por esse poder.

\footnotetext{
${ }^{1}$ Arts. 106 a 110 da Constituição Federal - Dos Tribunais Regionais Federais e dos Juízes Federais.
} 
Diversas soluções para o problema do aumento do volume de processos têm sido pensadas em todo o Judiciário, com algumas inclusive já colocadas em prática. Dentre todas, destacam-se medidas destinadas à contenção do crescimento processual e à agilização extrínseca e intrínseca do trâmite processual.

Quanto à contenção do crescimento processual, as idéias estão voltadas para a criação de leis que tornem o trâmite dos processos mais dinâmico, incentivando os acordos judiciais e extrajudiciais $^{2}$, e através de uma legislação que impeça a remessa de recursos aos Tribunais de Segundo Grau e principalmente aos Tribunais Superiores, dentre os quais se inclui o Superior Tribunal de Justiça - e ao Supremo Tribunal Federal ${ }^{3}$.

As soluções referentes à agilização extrínseca do trâmite processual estão voltadas para a criação de programas de treinamento de Servidores, não só nas áreas do direito, mas em diversas outras, como administração (notadamente na parte de gestão de pessoas, bens e recursos), estatística etc; por meio de propostas para ampliação do quadro de Servidores, Ministros e da carga horária ou acréscimo de novos turnos de trabalho; por meio da modernização do rito procedimental, por meio de reformas legais e constitucionais.

Para a agilização intrínseca do trâmite processual, busca-se a modernização do processo judicial e dos ritos procedimentais, atos e programas a eles vinculados, através implementação constante e crescente da tecnologia da informação e comunicação.

Maior acessibilidade, celeridade e efetividade processuais são os objetivos a serem alcançados por meio das medidas aqui mencionadas; pois, de fato, quanto mais acessível, célere e efetiva for a resposta jurisdicional, mais próximo o Poder Judiciário estará de seu ideal maior, ou seja, distribuir justiça, com o máximo de excelência.

\footnotetext{
2 Como exemplo dessas medidas: a Lei 9.099/1995, que criou os Juizados Especiais Cíveis e Criminais no âmbito da Justiça Estadual e a Lei 10.259/2001, que criou Juizados Especiais Cíveis e Criminais no âmbito da Justiça Federal.

${ }^{3}$ As Súmulas Vinculantes foram criadas no âmbito do Supremo Tribunal Federal, com esse propósito e a Lei 11.672/2008, que traz diretrizes acerca dos recursos repetitivos no Superior Tribunal de Justiça.
} 


\subsection{Problema e justificativa da pesquisa}

Assim como em outros Tribunais, a crescente demanda processual tem gerado dificuldades ao Superior de Justiça, na concretização de sua missão:

Processar e julgar as matérias de sua competência originária e recursal, assegurando a uniformidade na interpretação das normas infraconstitucionais e oferecendo ao jurisdicionado uma prestação acessível, rápida e efetiva ${ }^{4}$.

Para se ter uma idéia do aumento dos processos em trâmite no STJ, no ano de sua instalação (1989) e com 33 Ministros, a Corte julgou 3.711 processos (de 07/04 a 21/12/1989). No ano de 2007, com o mesmo número de Ministros, julgou 330.257 processos.

No gráfico 1, o quantitativo de processos julgados no STJ nos períodos de 1989 a 2007:

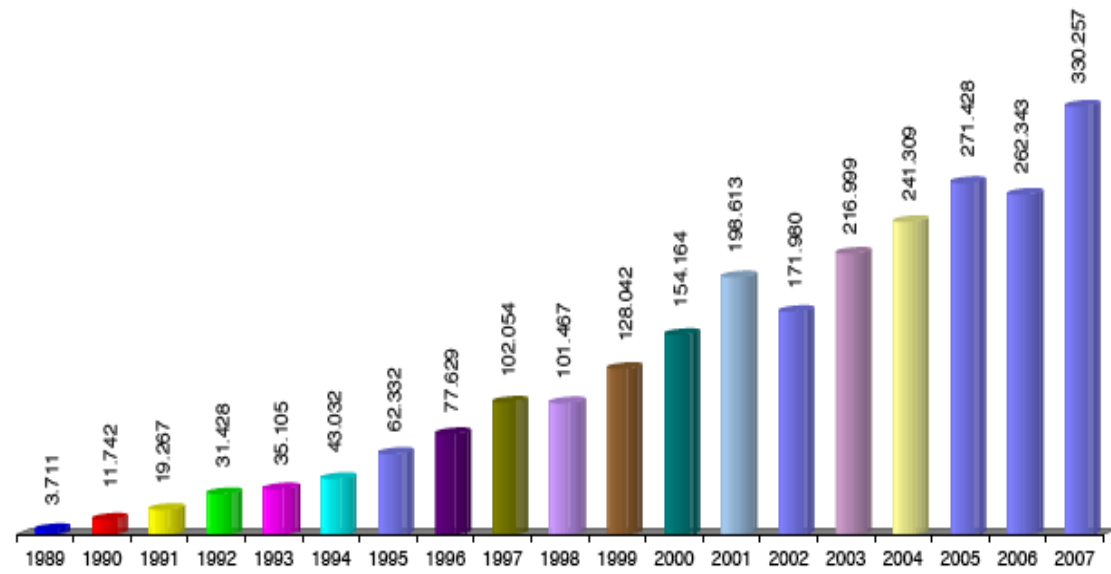

Gráfico 1: Processos julgados no período de 7/4/1989 a 31/12/2007.

Fonte: Superior Tribunal de Justiça. Disponível em: <http://www.stj.jus.br/webstj/ Processo/Boletim/verpagina.asp?vPag=0\&vSeq=112>. Acesso em 25 jan. 2009.

Nesse período, enquanto o volume de processos julgados aumentou em mais de 8.900\%, o número de Ministros permaneceu o mesmo (33).

\footnotetext{
${ }^{4}$ Plano de Gestão do Superior Tribunal de Justiça, biênio 2006-2008. Fonte: Assessoria de Gestão Estratégica.
} 
Não é razoável que sejam criados no STJ quantidade suficiente de cargos em proporção ao aumento de processos, pois isso significaria aumentar o numero de Ministros de 33 para 2.936, sem falar nos Servidores. Em razão disso, a contenção do crescimento processual torna-se uma medida, a princípio, mais razoável.

Esse aumento, somado ao meio físico que o processo se apresenta (papel) e à extensão territorial do país, acabam por comprometer os julgamentos dos processos judiciais no Superior Tribunal de Justiça, especificamente no que se refere à efetividade, celeridade e acessibilidade processuais.

Quanto à efetividade processual, com exceção das provas que não são documentais, como os objetos apreendidos, os demais documentos e provas são juntados aos autos. Como o processo pode ser retirado da secretaria por partes e advogados, existe o risco de subtração ou falsificação de provas e documentos. O STJ chegou a instalar câmeras nas salas de atendimento das Secretarias, onde advogados e partes analisam os autos, na tentativa de rechaçar o problema. No entanto, esse procedimento torna-se inócuo, quando partes e advogados fazem carga dos autos, retirando-os das Secretarias.

Em determinados processos, muitos com mais de 100 volumes e mais de 20.000 páginas, é extremamente trabalhoso encontrar determinado documento ou prova nos autos, tanto pelo trabalho físico de manusear vários volumes, como pela quantidade e variedade de provas e documentos agregados.

A celeridade processual fica comprometida em razão da quantidade de partes em determinados processos e o direito que cada uma das partes tem de retirar os autos para análise, muitas vezes atrasa em demasia o julgamento do mesmo. Da mesma forma, órgãos como o Ministério Público tem o direito de analisar e retirar os autos. 
Cada processo é, em regra, uno e material e não pode estar em "dois ou mais lugares ao mesmo tempo". Por outro lado, para que uma decisão ${ }^{5}$ seja elaborada, o processo deve estar fisicamente no Gabinete do Ministro. Diante disso, caso o processo esteja com uma das partes, deve-se aguardar a devolução do mesmo, para que os autos sejam então encaminhados ao Gabinete para decisão. Atrasos rotineiros na devolução dos autos pelas partes e pelos advogados acabam por retardar a resolução do litígio. Quando não se tem interesse na resolução do litígio, por se temer uma resposta negativa a determinado interesse, por exemplo; retirar os autos e retardar sua devolução é uma forma de atrasar a resposta do Judiciário sobre o caso, com o prejuízo de pelo menos uma das partes. Além disso, a própria movimentação física (interna e externa) dos autos demanda por si bastante tempo.

Por fim, a acessibilidade processual pode ficar comprometida em virtude da grande extensão territorial do Brasil, que conta com vinte e sete estados e o Distrito Federal, e do fato do Superior Tribunal de Justiça se localizar fisicamente na Capital. O acesso das partes e advogados de outras localidades aos processos, que se encontram no STJ, é dificultado em razão de fatores como a falta de recursos financeiros e até mesmo tempo para o deslocamento, o que restringe o exercício pleno das garantias constitucionais do contraditório e da ampladefesa $^{6}$.

Os problemas expostos trazem enormes prejuízos sob vários aspectos ao trâmite dos processos na Corte e, conseqüentemente, à solução dos conflitos de interesses na via judicial.

\footnotetext{
${ }^{5} \mathrm{O}$ termo decisão é aqui mencionado em sentido lato e deve ser compreendido como qualquer provimento jurisdicional exarado por um Ministro, como por exemplo, despachos ordinatórios, decisões interlocutórias, votos etc.

${ }^{6}$ Contraditório e Ampla-Defesa são garantias constitucionais (art. 5, LV, da CF), referentes aos processos judiciais e administrativos. Segundo Dezen Júnior (2003, p. 81), o contraditório é "poder que cada parte no processo tem de resistir ao que a outra pretende", de contestar, de negar o que está sendo alegado. Já a garantia constitucional. Já a ampla defesa é o direito que a parte no processo tem de utilizar todos os meios de prova para provar o que alega, notadamente para se defender.
} 
A informatização do processo judicial poderá de alguma forma, solucionar ou ao menos minorar os problemas relacionados?

Para que esta pergunta seja respondida é preciso compreender o que é a informatização do processo judicial e a forma pela qual a mesma se dá. É preciso analisá-la sob o ponto de vista legal e suas regulamentações. Deve-se verificar o que precisa existir para que ela se torne realidade. Ao final, caberá responder quais são os requisitos intrínsecos ao Poder Judiciário e extrínsecos a ele, para que a informatização do processo judicial ocorra.

Somente após percorrer esse longo caminho é que será possível responder tal pergunta e saber em que medida a informatização do processo judicial poderá contribuir para a acessibilidade, celeridade e efetividade processual.

Assim, o problema a ser estudado pode ser resumido com as seguintes expressões de pesquisa:

O QUE É INFORMATIZAÇÃO DO PROCESSO JUDICIAL? O QUE É NECESSÁRIO PARA IMPLEMENTÁ-LA? EM QUE MEDIDA ESSA PODE APRIMORAR A TRAMITAÇÃO DOS PROCESSOS JUDICIAIS NO SUPERIOR DE JUSTIÇA SOB OS ASPECTOS DA ACESSIBILIDADE, CELERIDADE E EFETIVIDADE PROCESSUAL?

\subsection{Objetivos}

O objetivo geral da pesquisa é entender a informatização do processo judicial, através de seu conceito, evolução, requisitos e conseqüências para o Superior Tribunal de Justiça.

Os objetivos específicos são:

i) Compreender o que é a informatização do processo judicial por meio da análise histórica do processo e da informação, do conceito de informatização do processo e da análise da legislação pátria sobre o tema; 
ii) Compilar os requisitos intrínsecos e extrínsecos necessários à informatização do processo judicial;

iii) Verificar o nível de implementação da informatização do processo judicial no STJ;

iv) Analisar o impacto da informatização do processo judicial no STJ sob os aspectos da acessibilidade, celeridade e efetividade processual;

\subsection{Metodologia}

No presente trabalho serão realizadas pesquisas de natureza histórica (buscando analisar a evolução da informação, da tecnologia e do volume de processos no Judiciário), documental (analisando as posições doutrinárias sobre os temas informação, tecnologia, sociedade e Judiciário; bem como análises estatísticas de dados sobre os temas), social (por meio da análise o fenômeno da informação na sociedade e o comportamento da mesma) e exploratória (verificando-se em que termos a informatização do processo judicial no STJ pode contribuir com a acessibilidade, celeridade e efetividade processual).

Quanto aos meios a serem utilizados, far-se-á pesquisas de campo por meio da coleta de dados estatísticos, documentais e pesquisas bibliográficas, onde se verificará o que já existe, em termos científicos e legais, sobre os temas abordados na pesquisa.

O método utilizado será o de meios técnicos (MATHIAS-PEREIRA, 2007), através de análises observacionais, comparativas, estatísticas e doutrinárias.

A pesquisa buscará elementos estatísticos, sociais, históricos, legais e teóricos, tendo como foco a compreensão da informatização do processo judicial e suas conseqüências. 


\section{INFORMAÇÃO E SOCIEDADE DA INFORMAÇÃO}

Durante muito tempo a ciência enxergou a inteligência humana como algo uno. Golleman (2001), entretanto, sugere que o cérebro humano não possui somente uma inteligência, mas várias. Diversos tipos de inteligência são estudados hoje pela ciência, dentre as quais se podem destacar: inteligência interpessoal (ligada aos relacionamentos entre pessoas); inteligência intrapessoal (ligada ao relacionamento do indivíduo com ele mesmo); inteligência emocional (ligada às emoções), inteligência espacial (ligada ao senso de localização, direção e espaço); inteligência musical (ligada aos sons e à musica); inteligência lingüística (ligada ao uso da palavra); inteligência lógica (ligada ao raciocínio e aos números); e inteligência corporal (ligada ao conhecimento do próprio corpo).

Apesar do enfoque em cada uma das inteligências ser diverso, todas possuem algo em comum: tanto o pensar quanto o sentir dependem de informações. A inteligência musical, por exemplo, é acionada por meio das informações transmitidas pelo ouvido ao cérebro quando esse capta determinado som ou música. A inteligência emocional é utilizada quando se surge algum estímulo capaz de gerar emoção, como um pensamento. A inteligência linguiística, da mesma forma, é acionada por meio de informações obtidas pela nossa capacidade de compreender o que se está sendo falado. A informação, assim, é o substrato para o raciocínio e para a emoção, é a principal matéria utilizada pelo cérebro em sua atividade de processamento.

Com o desenvolvimento das mais diversas áreas da ciência, notadamente a da tecnologia que proporcionou o surgimento das redes, a informação passou a ser compartilhada por toda a sociedade em tempo real. A tecnologia, através dos mais variados meios de informação e da informática derrubou barreiras que impediam a propagação da informação. Conceitos e diagnósticos médicos, por exemplo, que antes ficavam restritos ao especialista, 
agora podem ser facilmente estudados e compreendidos (ao menos superficialmente), através da utilização de sites de pesquisa na internet como o Google.

Castells (1999, p. 497) fala em uma sociedade em rede, que liga as pessoas e as instituições por meio da informação. É o que se chama de "sociedade da informação".

Surgido no fim do século XX, o termo Sociedade da Informação, conhecido também como Sociedade do Conhecimento ou Nova Economia, teve origem no termo "Globalização" e se refere à sociedade cuja informação é o elemento formador e construtor do conhecimento e essencial em todos os segmentos da vida em sociedade.

Takahashi (2002) destaca que o termo "Sociedade da Informação" existe desde a década de 1970, com o objetivo de descrever o estágio seguinte das sociedades industrializadas. A terminologia ganhou destaque na década de 1990 em contraposição ao termo "National Information Infra Structure", criado pelos Norte Americanos.

No Brasil, a publicação do Livro Verde - Sociedade da Informação no Brasil (2000) pelo Ministério da Ciência e Tecnologia demonstra a importância do tema para o crescimento e desenvolvimento da nação.

A razão de ser do livro está bem delineada em sua apresentação:

Esse livro contempla um conjunto de ações para impulsionarmos a Sociedade da Informação no Brasil em todos os seus aspectos: ampliação do acesso, meios de conectividade, formação de recursos humanos, incentivo à pesquisa $e$ desenvolvimento, comércio eletrônico, desenvolvimento de novas aplicações.

Takahashi (2002) afirma que "o problema central que uma Sociedade da Informação deve vencer, em primeira instância, é o da Exclusão Digital". Os "excluídos digitalmente" devem ser entendidos como aqueles que ainda não tem acesso aos insumos da tecnologia da informação e da comunicação e, se o têm, não possuem conhecimento para utilizar esses mecanismos. 
O avanço e popularização da internet em nível mundial, que tiveram início no final do último século e vêm aumentando expressivamente na primeira década deste novo milênio, têm resultado em uma conexão interplanetária entre todos os povos, crenças e raças.

É exatamente o conceito de rede que caracteriza a forma de ligação entre as pessoas na Sociedade da Informação. E rede, para a compreensão do termo "Sociedade da Informação", segundo Castells (2001, p. 498) "é o conjunto de nós interconectados".

Castells (1999,p. 497), assim se manifesta quanto à importância das redes na era da informação:

\begin{abstract}
(...) as funções e os processos dominantes na era da informação estão cada vez mais organizados em torno de redes. Redes constituem a nova morfologia social de nossas sociedades, e a difusão da lógica de redes modifica de forma substancial a operação e os resultados dos processos produtivos e de experiência, poder e cultura. Embora a forma de organização social em redes tenha existido em outros tempos e espaços, o novo paradigmas da tecnologia da informação fornece a base material para sua expansão penetrante em toda a estrutura social. Além disso, eu afirmaria que essa lógica de redes gera uma determinação social em nível mais alto que a dos interesses sociais específicos expressos por meio das redes: o poder dos fluxos é mais importante que os fluxos do poder. A presença na rede ou a ausência dela e a dinâmica de cada rede em relação às outras são fontes cruciais de dominação e transformação de nossa sociedade: uma sociedade que, portanto, podemos chamar de sociedade em rede, caracterizada pela primazia da morfologia social sobre a ação social.
\end{abstract}

Informações decorrentes de uma sociedade organizada em redes não têm barreiras de tempo e espaço em um universo virtual instantâneo e on line. Barreiras geográficas, culturais, religiosas dentre outras vem caindo como peças de dominó para dar lugar a uma nova sociedade. A sociedade globalizada por meio da informação, a verdadeira sociedade da informação.

No decorrer do presente trabalho, serão explorados vários dos aspectos relacionados à informatização do processo judicial, como o seu conceito, elementos, aplicabilidade e benefícios.

Por enquanto, pode-se afirmar que a virtualização do processo exige a informatização nos dois extremos da relação processual - Poder Judiciário e Partes no processo. 
No Superior Tribunal de Justiça já foram implementados vários dos elementos nos quais a informatização plena do processo se pauta, como a petição eletrônica, o diário de justiça on line dentre outros.

Não obstante todos os benefícios já elencados pelo processo virtual, estaria a população brasileira preparada para absorver tamanha transformação?

De fato, o art. $9^{\circ}, \S 3^{\circ}$ da Lei n. ${ }^{\circ} 11.419 / 2006$ dispõe que "os órgãos do Poder Judiciário deverão manter equipamentos de digitalização e de acesso à rede mundial de computadores à disposição dos interessados para a distribuição de peças processuais".

Apesar da benesse oriunda do mencionado dispositivo legal, levando-se em consideração a quantidade de demandas judiciais em todo o país, haveria sério risco do Poder Judiciário não suportar uma procura massiva em busca de computadores e digitalizadores por partes e advogados, em caso de uma população sem qualquer acesso à informática e seus equipamentos.

O esforço conjunto dos órgãos governamentais e da sociedade civil para que ambas as camadas da sociedade possam ter acesso e se beneficiarem das inovações tecnológicas é chamado de inclusão digital.

Silva Filho (2003) destaca que a inclusão digital está fundamentada em três pilares: tecnologias da informação e comunicação; renda e educação.

As tecnologias da informação e comunicação são o elemento gerador da informatização do processo judicial. Enquanto a legislação apenas regulamenta a forma com que se fará a virtualização do processo, são as chamadas "TIC's” que transformam "o sonho em realidade".

A renda é elemento essencial para que a população possa ter acesso às tecnologias disponíveis. Isto pois tal acesso em grande parte das vezes gera custos. Segundo o Silva Filho 
(2003), medidas governamentais fulcradas em disponibilizar acesso a terminais de computadores e correio eletrônico a toda a população; oferecer tarifas reduzidas para uso dos sistemas de telecomunicações; e criar mecanismos de isenção fiscal, sem muita burocracia, para o recebimento de doações de computadores e equipamentos de infra-estrutura, são pontos fundamentais na garantia do acesso à tecnologia a todos os seguimentos da sociedade, notadamente os mais carentes.

A educação é, outrossim, elemento de pontual importância no processo de inclusão digital. As tecnologias da informação e comunicação e a renda possibilitam ao cidadão o acesso ao mundo virtual. Isso, no entanto, não é suficiente, para que o processo de inclusão digital se complete. Imprescindível é o conhecimento capaz de permitir ao homem comum o manuseio da tecnologia oferecida.

Com base nesses três aspectos, o Governo Federal tem buscado proporcionar a toda a sociedade brasileira o acesso e utilização dos insumos tecnológicos por meio da inclusão digital.

O website governamental "Inclusão Digital" (www.inclusaodigital.gov.br), elenca vários projetos realizados pelo governo, em parceria com a sociedade civil, no sentido de expandir ao máximo a inclusão digital no Brasil.

A seguir, alguns dos projetos atualmente desenvolvidos segundo o website mencionado:

\section{Centros de Inclusão Digital}

O Programa constitui-se em um instrumento de promoção da inclusão social, cuja responsabilidade é da Secretaria de Ciência e Tecnologia para Inclusão Social (SECIS) e tem como objetivo proporcionar à população menos favorecida o acesso às tecnologias de informação, capacitando-a na prática das técnicas computacionais, voltadas tanto para o aperfeiçoamento da qualidade profissional quanto para a melhoria do ensino. 


\section{Computador para Todos}

Voltado para a classe $\mathrm{C}$, permite à indústria e ao varejo a oferta de computador e acesso à Internet a preços subsidiados, e com linha de financiamento específica, além da isenção de impostos PIS/COFINS. PCs de até R \$ 1.200 que obedeçam à configuração mínima podem ser parcelados em prestações de $\mathrm{R} \$ 50$.

\section{CVT - Centros Vocacionais Tecnológicos}

Os CVTs estão direcionados para a capacitação tecnológica da população, como uma unidade de formação profissional básica, de experimentação científica, de investigação da realidade e prestação de serviços especializados, levando-se em conta a vocação da região onde se insere, promovendo a melhoria dos processos.

\section{Gesac - Governo Eletrônico Serviço de Atendimento ao Cidadão}

O Gesac garante conexão via satélite à Internet a escolas, telecentros, ONGs, comunidades distantes e bases militares fronteiriças, além de oferecer serviços como conta de e-mail, hospedagem de páginas e capacitação de agentes multiplicadores locais, contando hoje com 3.530 pontos de presença atendendo cerca de 2.200 municípios brasileiros.

\section{Kits Telecentros}

A doação de kits telecentros para prefeituras brasileiras é uma iniciativa do Programa de Inclusão Digital do Ministério das Comunicações que tem como meta instalar telecentros em todos os 5,5 mil municípios do país até junho de 2008, com investimentos totais de $\mathrm{R} \$ 134$ milhões do governo federal.

\section{Observatório Nacional de Inclusão Digital}

Aglutina informações sobre todos os programas de inclusão digital do governo federal no portal http://www.inclusaodigital.gov.br, com notícias, links, eventos e materiais de referência.

\section{Pontos de Cultura - Cultura Digital}

O Programa Cultura Viva apóia iniciativas culturais locais/populares e tem como ação prioritária o Ponto de Cultura que articula as demais ações do Programa.

\section{Programa Banda Larga nas Escolas}

Programa Banda Larga nas Escolas vai beneficiar cerca de 55 mil escolas até 2010, atendendo $84 \%$ dos estudantes do ensino básico do país.

\section{Programa Computador Portátil para Professores}

O Programa visa criar condições para facilitar a aquisição de computadores portáteis para professores da rede pública e privada da educação básica, profissional e superior, credenciadas junto ao MEC, a baixo custo e condições diferenciadas de empréstimo, com vistas a contribuir com o aperfeiçoamento da capacidade de produção e formação pedagógica dos mesmos, através da interação com a tecnologia da informação e comunicação. 


\section{ProInfo - Programa Nacional de Informática na Educação}

O programa funciona de forma descentralizada, sendo que em cada Unidade da Federação existe uma Coordenação Estadual do ProInfo, cuja atribuição principal é a de introduzir o uso das tecnologias de informação e comunicação nas escolas da rede pública, além de articular as atividades desenvolvidas sob sua jurisdição, em especial as ações dos Núcleos de Tecnologia Educacional (NTEs).

\section{Projeto Computadores para Inclusão}

Implantação de um sistema nacional de recondicionamento de computadores usados, doados pelas iniciativas pública e privada, recondicionados por jovens de baixa renda em formação profissionalizante, e distribuídos a telecentros, escolas e bibliotecas de todo o território nacional.

\section{Quiosque do Cidadão}

O Projeto Quiosque do Cidadão instala computadores conectados à Internet banda larga em bibliotecas públicas, escolas ou em outros espaços públicos.

\section{Territórios Digitais}

A implantação de Casas Digitais - espaços públicos e gratuitos com acesso a computadores e Internet - em assentamentos, escolas agrícolas, comunidades tradicionais, sindicatos e Casas Familiares Rurais é um projeto, coordenado pelo Núcleo de Estudos Agrários e Desenvolvimento Rural (NEAD), que faz parte do Programa Territórios da Cidadania do MDA.

\section{UCA - Projeto Um Computador Por Aluno}

O Projeto Um Computador Por Aluno (UCA) tem a finalidade de promover a inclusão digital, por meio da distribuição de 1 computador portátil (laptop) para cada estudante e professor de educação básica em escolas públicas.

Os reflexos da inclusão digital no Brasil já podem ser sentidos de forma significativa. Uma pesquisa sobre o "Uso das Tecnologias da Informação e Comunicação no Brasil", realizada pelo Centro de Estudos sobre as Tecnologias da Informação e da Comunicação, e divulgada no ano de 2008 no website do Centro de Estudos das Tecnologias da Informação e Comunicação (www.cetic.br), menciona dados robustos e subsistentes a demonstrar o que hora se afirma.

A figura 1 traz a evolução da posse e uso de computadores e internet nos domicílios brasileiros entre os anos de 2005 a 2007: 


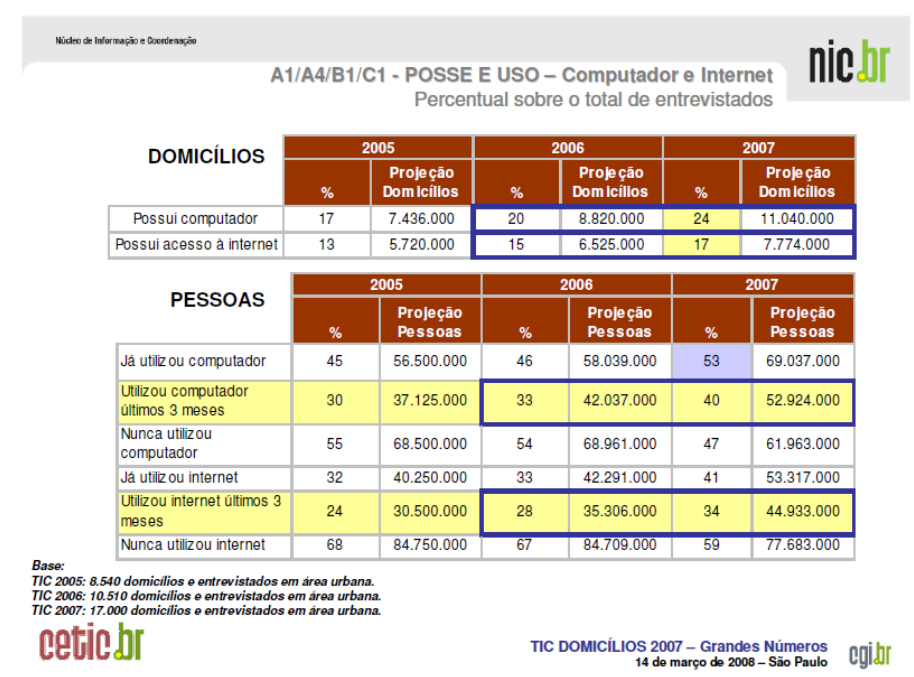

Figura 1 Posse e Uso - Computador e Internet, por renda.

Fonte: Centro de Estudos das Tecnologias da Informação e Comunicação.

Disponível em: <www.cetic.br>. Acesso em 25 jan. 2009.

Segundo a figura 1, de 2005 a 2007 houve um crescimento de 7\% no número de domicílios com computador no país sendo e um aumento de $4 \%$ em relação ao uso da internet nesses. Em 2007, 24\% dos lares brasileiros já possuíam computador e, 17\% dos mesmos lares já possuíam acesso à internet.

O uso da internet pelo cidadão brasileiro aumentou $10 \%$ no mesmo período. Enquanto em 2005, 24\% da população utilizava internet, em 2007 esse número foi para 34\%.

Levando em consideração as classes sociais pré-determinadas em razão da renda mensal familiar, pode-se perceber que os seguimentos de computadores e internet, vêm apresentando crescimento, mesmo nas famílias com menor renda mensal.

A figura 2 traz o crescimento do segmento de internet "banda larga", ou seja, de alta velocidade, entre os anos de 2005 a 2007: 


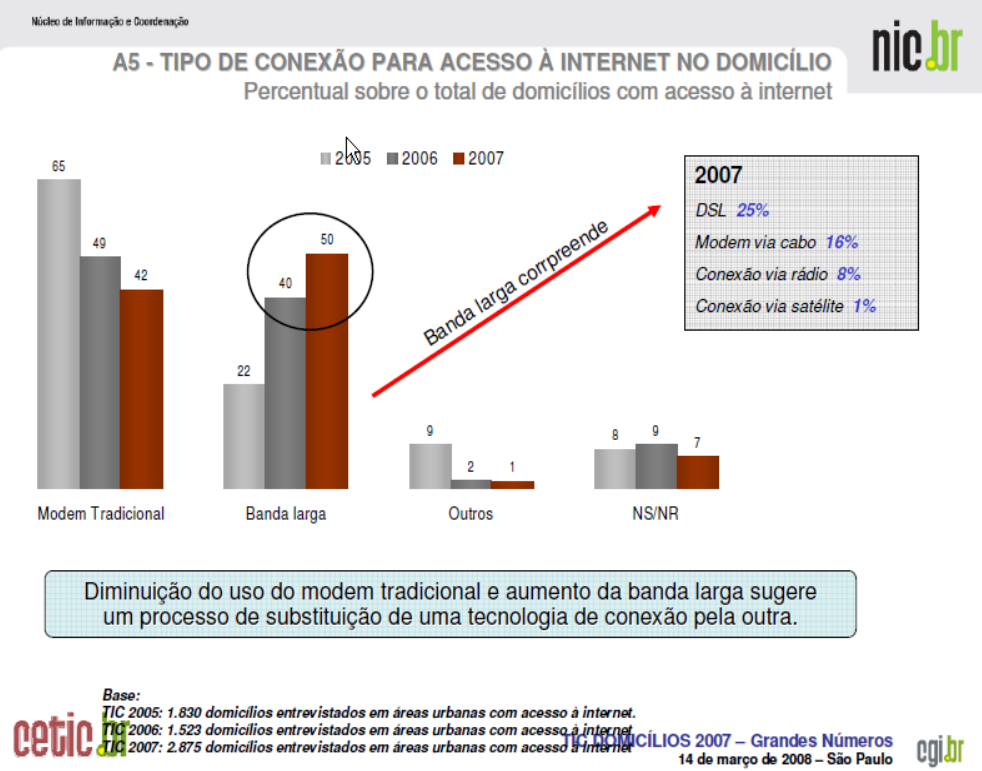

Figura 2: Tipo de Conexão para acesso à Internet no Domicílio.

Fonte: Centro de Estudos das Tecnologias da Informação e Comunicação. Disponível em: $<$ www.cetic.br>. Acesso em 25 jan. 2009.

Entre os anos de 2005 a 2007, constata-se um aumento expressivo no uso do tipo de conexão "banda larga" - alta velocidade, no uso da internet - em torno de $28 \%$, e uma redução proporcional no uso de internet via linha telefônica "discada", por modem tradicional, em 32\%. O fenômeno ora mencionado é evidente em todas as classes sociais, conforme demonstra a figura 3 :

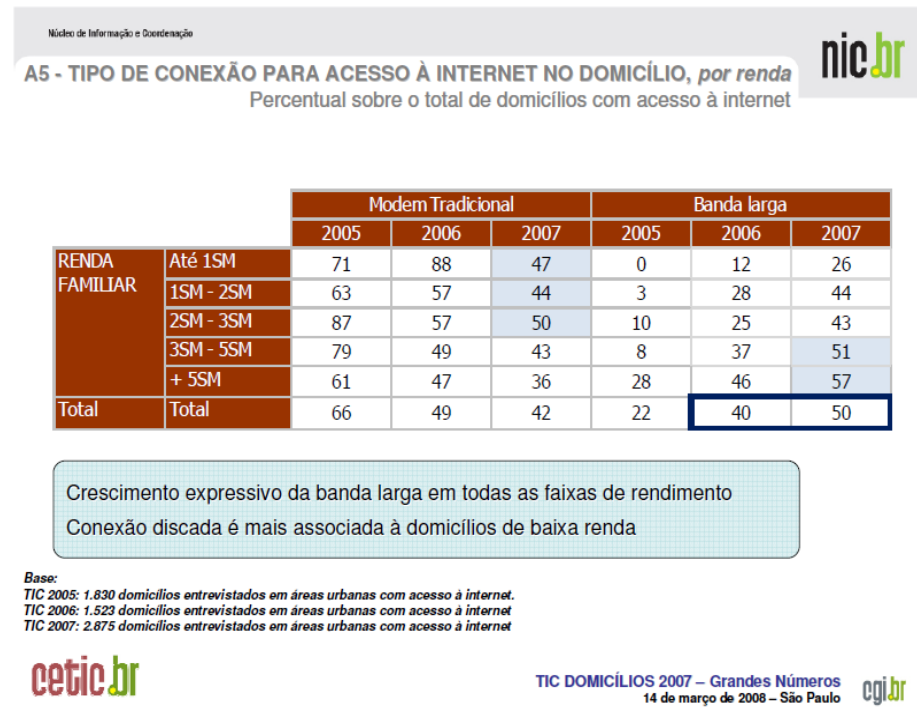

Figura 3: Tipo de Conexão para acesso à Internet no Domicílio, por renda.

Fonte: Centro de Estudos das Tecnologias da Informação e Comunicação. Disponível em: <www.cetic.br>. Acesso em 25 jan. 2009. 
Os dados expostos, demonstram que a inclusão digital está em franco desenvolvimento no país, seja por meio da série de projetos que vem sendo desenvolvidos pela administração pública em parceria com a sociedade civil, muitos dos quais foram aqui relatados; seja por meio da interpretação dos números constantes da pesquisa sobre o uso das tecnologias da informação e da comunicação no Brasil, que demonstram um franco crescimento no número de computadores e do uso da internet nos domicílios brasileiros.

As transformações decorrentes da era da informação ajudam a promover a inclusão digital, o que é elemento essencial para a informatização do processo judicial, como se verá adiante.

Todo o Poder Judiciário, e conseqüentemente o Superior Tribunal de Justiça, utiliza a informação para o exercício da tutela jurisdicional. Essa informação chega ao "Juiz" (Ministro no STJ), que a analisa e verifica se é caso de resposta por parte do Poder Judiciário. Em caso positivo, forma-se ou dá-se continuidade ao processo judicial, instrumento necessário para que seja garantido um direito ou imposta uma obrigação. A informação que interessa ao Poder Judiciário é aquela que é capaz de garantir direitos e gerar obrigações, por meio da solução de litígios.

A tarefa do Poder Judiciário é de grande importância e responsabilidade, na medida em que esse lida essencialmente com direitos e obrigações. A qualidade da informação necessária à resposta judicial está diretamente relacionada à gestão do processo judicial, pois é por meio desse que a informação chega ao julgador e que solucionará a lide. Por isso, quanto maior a qualidade na gestão do processo judicial, maior será a qualidade da tutela jurisdicional oferecida pelo STJ.

Jamil (2001, p. 204-206), afirma que a tomada de uma decisão correta se dá por meio de uma informação de qualidade; e que ter informação de qualidade, significa deter poder. No 
ponto de vista do autor, sete aspectos são essenciais para que uma a mensuração da qualidade da informação: atualidade, segurança/confiabilidade da fonte, volume, pontualidade, flexibilidade, custos, objetividade. Todos esses aspectos têm profunda relevância com a atividade de julgar exercida pelo Poder Judiciário.

A informação deve ser "atual", para que chegue ao destinatário da forma mais atualizada possível. A partir do momento que a informação deixa de estar atualizada, ela pode perder o nexo com a realidade e acarretar conseqüências indesejáveis.

Deve a informação ser “confiável e segura”, pois uma informação que não condiz com a realidade pode gerar uma resposta judicial distorcida. A informação deve possuir um "volume" adequado, contendo somente o que interessa para a resposta judicial, sem ser incompleta ao mesmo tempo. Tanto a informação desnecessária quanto a informação insuficiente podem prejudicar a resposta judicial. A informação deve ainda ser "pontual", pois se chegar ao processo após ter sido o caso decidido poderá ser inútil, apesar de retratar a realidade. A informação deve ser "flexível", na medida em que possa ser esmiuçada e remontada sem haver prejuízos ao seu conteúdo.

A qualidade da informação está relacionada, ainda, ao "custo" da mesma, pois quanto mais barata for a informação, mais viável será seu processamento. Por fim, a informação deve ter "objetividade" na medida em que "deverá se prender a um contexto, podendo ser aplicada de imediato e produzir o resultado esperado" (JAMIL, 2001, p. 206).

\subsection{Governo Eletrônico}

Ferrer (2004, p. IX) conceitua Governo Eletrônico como “o conjunto de serviços e o acesso a informações que o governo oferece aos diferentes atores da sociedade civil por meios eletrônicos". 
Sobre a importância do Governo Eletrônico, Ferrer (2004) destaca na introdução de sua obra:

Se para todos os países, o Governo Eletrônico é uma indiscutível ferramenta de cidadania e aumento da eficiência da máquina pública, para os países emergentes sua função é ainda mais importante: é uma indiscutível ferramenta de desenvolvimento (...). Entrar na economia digital não é uma opção, é uma tarefa indiscutível dos governos. As diferentes tarefas envolvidas no Governo Eletrônico, ao mesmo tempo em que mudam o relacionamento com a sociedade, criam ferramentas para desobstruir o dinheiro público, antes emaranhado em estruturas burocráticas.

A difusão da internet no Brasil permitiu aos três Poderes da República (Executivo, Legislativo e Judiciário) implementarem uma série de serviços capazes de facilitar a vida do cidadão brasileiro e otimizar a administração pública.

Segundo Parentoni (2004, p. 22), a utilização da modalidade licitatória "Pregão" pela Administração Pública, adotada preferencialmente na forma eletrônica, constitui um grande avanço no segmento de Governo Eletrônico. Atos notoriais e de registro já podem ser solicitados, igualmente, por meio da internet.

Além desses, perdem-se de vista todos os serviços públicos disponibilizados ao cidadão por meio da internet, dentre os quais destacam-se a retirada de certidões negativas nas diversas administrações tributárias, bem como o cálculo e expedição de guias para pagamento de tributos, inclusive com o cálculo de juros e multa; a possibilidade de acesso a projetos de lei nos diversos órgãos legislativos do país; e o acesso a toda a base da legislação federal disponível no website da Presidência da República (www.planalto.gov.br).

Apesar de pública, a máquina da administração não deixa de ser uma empresa e, como empresa que é não pode fechar os olhos aos avanços tecnológicos capazes de facilitar a estruturação e gestão de seus diversos segmentos, bem como a administração de todos a que a ela se subordinam. 
Uma pesquisa sobre o crescimento do Governo Eletrônico no Brasil, realizada pelo

Centro de Estudos sobre as Tecnologias da Informação e da Comunicação, e divulgada em 2008 no website do Centro de Estudos das Tecnologias da Informação e Comunicação (www.cetic.br), acesso em 25/01/2009, traz alguns dados relevantes sobre o crescimento deste segmento no país:

- $25 \%$ da população brasileira com mais de 16 anos usou a Internet para interagir com órgãos públicos em 2007;

- O uso de serviços de Governo Eletrônico entre os brasileiros acima de 16 anos cresce consideravelmente segundo o grau de instrução, a renda familiar e a classe social;

- O perfil econômico do brasileiro que usa serviços de Governo Eletrônico é composto por $5 \%$ de indivíduos da classe A, $36 \%$ da classe B, $48 \%$ da classe C, e $11 \%$ das classes DE;

- Educação é fundamental para que o brasileiro possa se beneficiar desse tipo de serviços - apenas $12 \%$ daqueles que estudaram até o Ensino Fundamental compõem o total de usuários, enquanto $49 \%$ informam ter finalizado o Ensino Médio, e $39 \%$ o Superior;

- O serviço de Governo Eletrônico mais popular entre os brasileiros ainda é a "consulta ao CPF", atividade realizada por 59\% das pessoas que utilizam a rede para se comunicar com órgãos públicos.

Apesar do comprovado desenvolvimento do Governo Eletrônico, o Poder Judiciário detém uma parcela tímida de participação direta no segmento, com a fatia de $15 \%$ do total de entrevistados, conforme demonstra o gráfico 2:

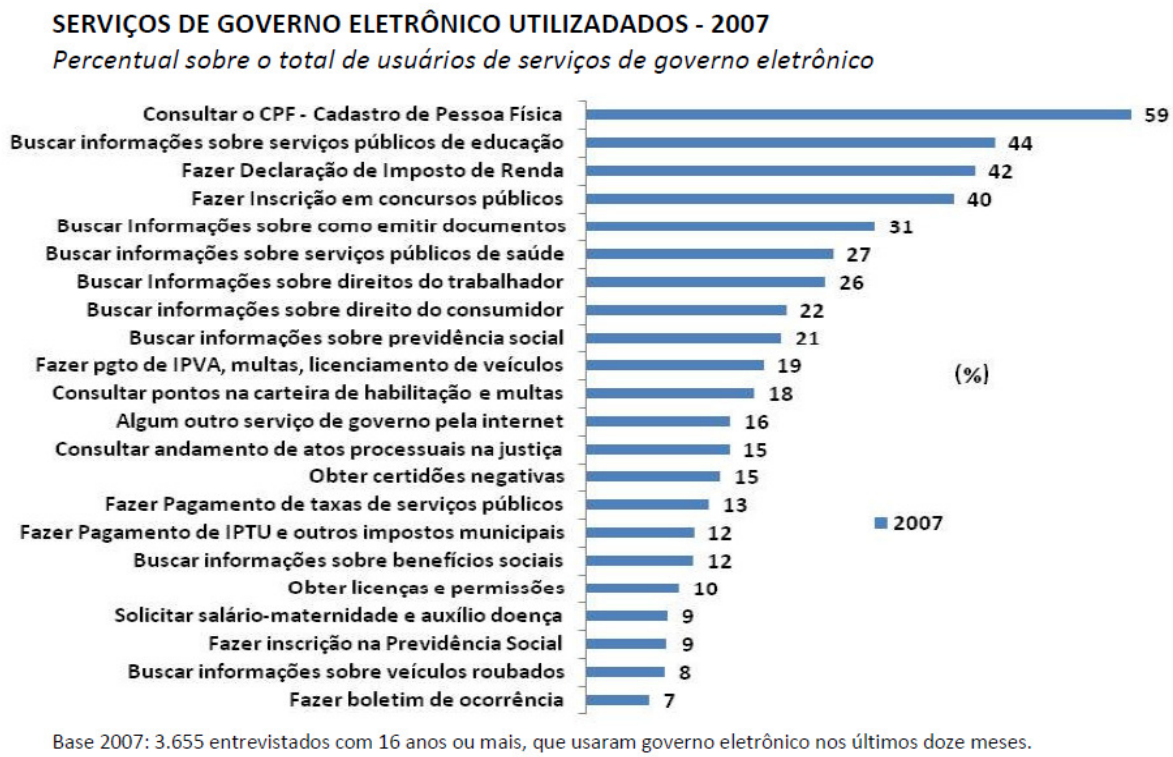

Gráfico 2: Serviços de Governo Eletrônico utilizados em 2007.

Fonte: Centro de Estudos das Tecnologias da Informação e Comunicação. Disponível em:

$<$ www.cetic.br>. Acesso em 25 jan. 2009. 
Quando os entrevistados foram questionados sobre quais serviços de Governo Eletrônico gostariam de utilizar, a parcela de participação do Judiciário aumentou, conforme o gráfico 3:

SERVIÇOS DE GOVERNO ELETRÔNICO QUE GOSTARIA DE UTILIZAR

Percentual sobre o total de pessoas que não usaram serviços de governo eletrônico

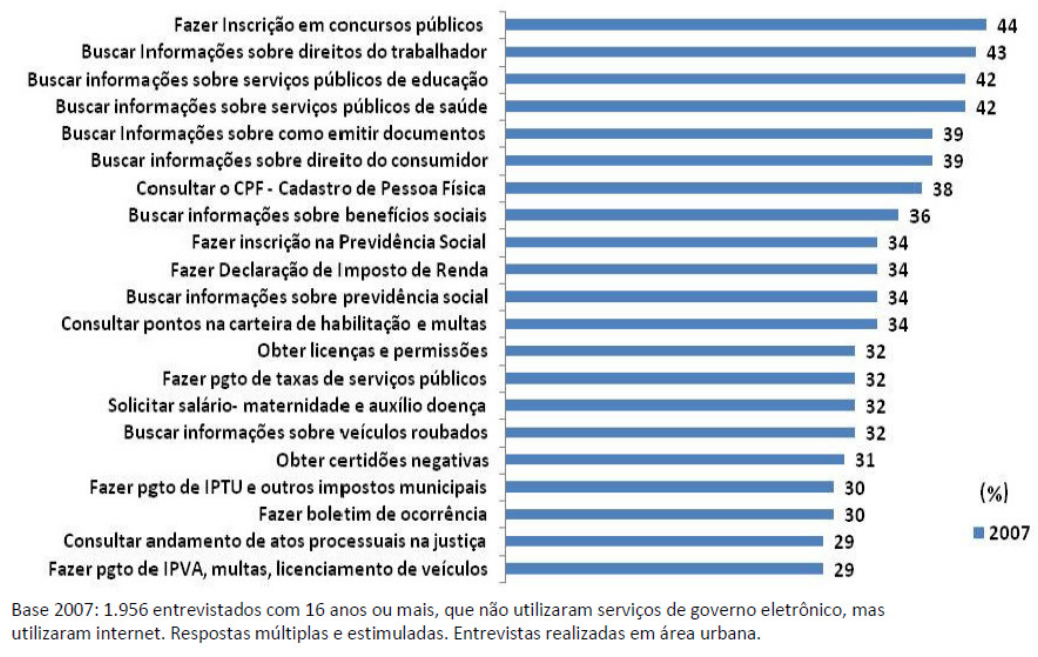

Gráfico 3: Serviços de Governo Eletrônico que o cidadão Brasileiro gostaria de utilizar. Fonte: Centro de Estudos das Tecnologias da Informação e Comunicação. Disponível em: <www.cetic.br>. Acesso em 25 jan. 2009.

A utilização dos serviços de Governo Eletrônicos disponibilizados pelo Poder Judiciário deverá, em regra, ser sempre menor que a de outros serviços, como o de consulta ao $\mathrm{CPF}$, por exemplo. Isso se justifica pelo fato de que todo brasileiro maior de idade deve ter um CPF. No entanto, nem todos esses brasileiros são partes em processos judiciais em curso.

Por fim, espera-se que a informatização do processo judicial em todo o Poder Judiciário pátrio contribua para aumentar a participação do cidadão no segmento Governo Eletrônico.

Mas seria possível o inter-relacionamento entre os mundos jurídico e tecnológico? 


\subsection{Mundo Jurídico e Tecnologia}

É possível imaginar o inter-relacionamento entre os mundos o jurídico e o tecnológico, na realidade, ele já existe. Esse relacionamento entretanto é compatível?

Reale (2002, p. 63) afirma que a Ciência Jurídica "é uma ciência de estruturas normativas, e, mais propriamente, de modelos jurídicos". O direito positivo está calcado em normas elaboradas pelos homens. As leis ditam o "dever ser" no que se refere à conduta humana. Por isso, afirma-se que a ciência jurídica possui estrutura normativa.

Por outro lado, a tecnologia é ciência exata e não social, que se submete diretamente às leis da natureza, como à eletricidade, à resistência dos metais etc. Em termos de tecnologia, pode o homem até mesmo instituir convenções, buscar novas formas de se chegar ao mesmo lugar, mas não pode, até o presente, alterar as leis básicas da física, da matemática e da química.

No direito é possível instituir normas e princípios contrários às leis da natureza. Já na ciência tecnológica, não se pode olvidar as regras da física e das outras disciplinas exatas. O Direito pode até mudar a forma de pensar dos homens, mas a tecnologia não pode mudar a natureza das coisas, em toda a sua extensão. Determinado delito pode deixar de o ser. A gravidade, por seu turno, poderá até ser chamada de outro nome, mas continuará gerando a atração dos corpos queira o homem ou não. Apesar disso, vários estudiosos entendem possível a coexistência entre essas duas ciências.

Benucci (2007, p. 50) menciona o fato de o introdutor da expressão "cibernética", Norbert Wiener, ter constatado que os ramos mais fecundos das diversas ciências estão situados nos limites separadores das mais diversas áreas científicas. Para Benucci, "esse caráter interdisciplinar da cibernética manifesta-se também quando sua aplicação volta-se ao 
direito". Relembra o autor o nome de Lee Loevinger, outro analista da compatibilidade entre a ciência jurídica e a tecnologia, que em trabalho publicado em 1949, defendeu a criação de uma nova disciplina jurídica - a Jurimetria - que teria a missão de, por meio de métodos quantitativos racionalizar o direito, utilizando o processamento eletrônico de dados jurídicos, a lógica e a análise comportamental das decisões judiciais.

Losano (1979, p. 254) dividiu em duas vertentes o processo eletrônico no mundo jurídico. Na primeira vertente estariam as atividades de natureza repetitiva (juntada de documentos, elaboração de mandados de intimação, citação e editais, por exemplo), as quais seriam plenamente substituídas pela utilização do computador, por meio de modelos gerais. Nessa vertente, o trabalho humano seria no mínimo, fundido com o trabalho realizado pelo computador, quando não substituído plenamente por esse.

A segunda vertente do processo eletrônico no mundo jurídico segundo Losano (1979, p. 254) estaria relacionada com as atividades de cunho eminentemente intelectual, cujo raciocínio envolvesse valoração de normas, condutas e fatos. Nessa vertente, a máquina não pensaria pelo homem, mas tão somente o auxiliaria em pesquisas e modelos quando possíveis.

Por seu turno, Madalena e Oliveira (2008), no decorrer do de todo o livro “Organização e Informática no Poder Judiciário: Sentenças Programadas em Processo Virtual", defendem uma maior utilização da informática nos aspectos abordados pela segunda vertente proposta por Losano (1979, p. 254), através do uso da inteligência artificial em sentenças programadas. O mecanismo proposto por Madalena e Oliveira (2008) está fundamentado da seguinte forma: por meio do uso da lógica e da análise valorativa, encontrar-se-ia para determinado caso (ex.: roubo mediante o uso de arma de brinquedo), todas as soluções possíveis para a resolução da controvérsia, com todas as suas variáveis. Todas as soluções abasteceriam um software específico a ser utilizado pelo Magistrado. 
Informadas então as circunstâncias do suposto delito pelo Magistrado, o programa analisaria e cruzaria os dados, chegando a um veredicto, que poderia ser, ou não, acatado pelo Magistrado. A lógica da inteligência artificial não permitiria à máquina pensar livremente como um humano, mas apenas cruzaria dados para se chegar a soluções pré-estabelecidas.

Apesar de vários projetos e sonhos sobre a possibilidade da inteligência artificial vir, ao menos parcialmente, substituir a atuação do Magistrado, no que concerne à segunda vertente proposta por Losano (1979, p. 254), Monteiro (2004, p. 478) adverte:

\begin{abstract}
A viabilidade de um Juiz Proteus sob a forma de um SEL de base argumentativa, leva ao necessário debate sobre a verificabilidade dos postulados da Lógica da Argumentação Jurídica. Se longe pode ir um KBS composto de elementos discursivos, o problema está no grau de certeza que tal verificação poderia alcançar. Um dos desafios mais óbvios das modernas teorias da argumentação jurídica está nas insuficiências dos processos de verificação empírica a que elas podem ser submetidas. A adoção de tal sistema poderia incorrer nas mesmas dificuldades do Direito Argumentativo (...).
\end{abstract}

No meio de todas essas transformações, surge o direito da informática, conceituado por Benucci (2007, p. 53):

O conjunto de relações jurídicas decorrentes da aplicação e desenvolvimento da informática, como o comércio eletrônico, as relações surgidas com a criação, uso, alteração e reprodução de softwares, e das relações humanas realizadas em redes. 


\section{A INFORMATIZAÇÃO DOS PROCESSOS JUDICIAIS E O PRINCÍPIO DA LEGALIDADE NA ADMINSITRAÇÃO PÚBLICA}

A Constituição Federal de 1988 consagrou em seu art. 5º, inciso II, o princípio da legalidade, segundo o qual "ninguém será obrigado a fazer ou deixar de fazer alguma coisa senão em virtude de lei”.

Segundo esse princípio, a pessoa natural (física) ou jurídica (de natureza privada), somente é obrigada a fazer o que a lei determina que se faça, podendo ainda fazer tudo o que ela não proíbe.

Di Pietro (2008, p. 63) ressalta que a Administração Pública - dentro da qual está inserido o Poder Judiciário, como ente do Poder Público - "só pode fazer o que a lei permite". A autora destaca que tal legalidade possui conotação diferente do princípio da legalidade aplicável a relações entre particulares somente, onde se permite fazer tudo o que a lei não proíbe.

Essa consideração mostra-se relevante, tendo em vista que a pesquisa que ora se inicia tem como foco o Superior Tribunal de Justiça, órgão do Poder Judiciário e, por consequiência, do Poder Público.

Desta forma, por mais aprofundadas que sejam as pesquisas realizadas, por mais robustas que sejam os fundamentos teóricos apresentados e, por mais cristalinas e evidentes que sejam as conclusões, todo o esforço seria em vão se não houvesse autorização legal para a implementação do que se pretende.

Diferentemente seria o desfecho se objeto da implementação fosse uma empresa privada. Nesse caso, desde que as implementações a serem realizadas não violassem alguma 
determinação legal, essas poderiam ser materializadas sem qualquer problema, ao menos sob o âmbito legal.

Enquanto em uma empresa privada, eventual implementação pode ocorrer em qualquer amplitude, desde que não contrarie a Lei, no Superior Tribunal de Justiça e nos demais órgãos do Poder Público, qualquer implementação estará restrita a uma determinação legal, pois nesses somente se pode fazer o que a lei determina ou autoriza que se faça.

De fato, nem toda implementação depende necessariamente de uma lei em sentido estrito $^{7}$. Algumas determinações de ordem mais simples como aquisição de softwares (através de licitação), treinamento de pessoal entre outras, dependeriam apenas de ato legal emanado do próprio Tribunal, por meio de uma resolução, instrução normativa, como por exemplo, para instituir e regulamentar a petição eletrônica (Resoluções n. ${ }^{\circ} 2$ e 9 de 2007) e o diário de justiça eletrônico (Resolução n. ${ }^{\circ} 8$ de 2007), no STJ. Apesar disso, várias outras etapas importantes para a informatização do processo judicial foram e ainda serão disciplinadas por lei aprovada no Congresso Nacional.

Não obstante essa observação, a ausência de uma lei disciplinando o processo judicial informatizado não obstaria a presente pesquisa. Dificultaria como já dito, no entanto, a implementação das conclusões obtidas, se viáveis.

Em 20 de dezembro de 2006, foi publicada a Lei n. ${ }^{\circ} 11.419$ de 19 de dezembro de 2006, a qual "dispõe sobre a informatização do processo judicial; altera a Lei n. ${ }^{\circ}$ 5.869, de 11 de janeiro de 1973 - Código de Processo Civil; e dá outras providências”.

A vigência dessa lei veio contribuir para a realização do presente trabalho, pois apesar da restrição referente ao princípio da legalidade em se tratando do Poder Público, o que pode mitigar o alcance da pesquisa, a mesma terá um ponto de partida concreto e será realizada a

\footnotetext{
${ }^{7}$ Leis em sentido estrito são aquelas aprovadas pelo Congresso Nacional e de acordo com os aspectos material (conteúdo) e formal (procedimentos legislativos previstos) predeterminados. São exemplos de leis em sentido estrito as leis ordinárias e complementares.
} 
princípio, tomando por base o que lei já em vigor possibilita que se faça. Não ficando excluídas as conclusões cuja implementação dependam de posteriores regulamentações legais. Partir do abstrato, entretanto, seria a princípio tormentoso, pois utópico é imaginar e pretender que uma lei fosse aprovada com a finalidade de implementar as conclusões desta pesquisa.

Já os resultados, caso considerados viáveis e constatada alguma necessidade de implementação, poderiam mais facilmente se materializar, podendo encontrar obstáculos políticos, financeiros, de recursos humanos etc, mas não legais, pelo menos a princípio.

Desta forma, a pesquisa ora realizada estará pautada nos permissivos legais já existentes ou passíveis de existir e capazes de viabilizar o processo de informatização do processo judicial. 


\section{O PROCESSO E SUAS MODALIDADES}

Para uma melhor compreensão do presente trabalho e tendo em vista que ele não é direcionado apenas aos que atuam no universo jurídico, mas a toda a sociedade, importante se faz a conceituação do processo e suas modalidades, para que seja então possível tratar do processo judicial informatizado.

\subsection{Os Processos Judiciais e Administrativos}

Direito é a ciência que busca a solução dos conflitos por meio do exercício da tutela jurisdicional (jurisdição, juris-dictio, dizer o direito).

Nos países que utilizam o processo legislativo ${ }^{8}$ como meio de se "dizer o direito", pode-se diferenciar dois grupos de normas: as de direito material e as de direito formal.

Segundo Cintra, Grinover e Dinamarco (1997, p. 40), as normas de direito material são aquelas que contem a matéria, a substância do direito que se busca resguardar ou da obrigação que se pretende impor. São as normas que dizem o que se pode e/ou que não se pode fazer, que garantem direitos e que impõem obrigações. As normas de direito formal, são aquelas que se relacionam às maneiras ou formas de se obter ou garantir o que está previsto na norma de direito material.

Quando o STJ é provocado a "dizer o direito", esse direito deve, em regra, ser garantido por uma norma de direito material. A forma, entretanto, que um de seus Ministros irá proceder para gerar ou garantir esse direito, se dá com base em normas de direito formal.

\footnotetext{
${ }^{8}$ No processo legislativo regular o exercício da tutela jurisdicional é baseada em normas, trazidas à existência pelo Poder Legislativo. Diferentemente ocorre em países que aplicam a tutela jurisdicional por meio do direito consuetudinário (Ex.: Inglaterra), onde o direito é feito através dos costumes.
} 
O processo judicial é justamente o concatenado de atos, previstos em regra nas normas de direito formal, que são realizados pelo Poder Judiciário, para esse possa exercer sua tutela jurisdicional, dizendo o direito.

Esse processo é materializado no mundo real por meio dos autos ou autos do processo, que nada mais são que um conjunto de documentos, na sua maioria em papel, organizados em forma de pastas, nas quais estão contidos o pedido inicial (petição inicial), provas, alegações, pareceres e, por fim, a resposta judicial ou provimento jurisdicional (decisão, sentença ou acórdão).

No âmbito da Administração Pública, além dos processos judiciais, existem também os processos administrativos, nos quais se busca dar uma resposta a determinada demanda, mas não por meio do emprego da tutela jurisdicional, que é exclusiva do Poder Judiciário, mas sim pela atividade dos Juízes em todos os graus de jurisdição ${ }^{9}$. Processos licitatórios, no âmbito do Poder Executivo, por exemplo, são modalidades de processo administrativo.

\subsection{O Processo Judicial Eletrônico}

A Lei n. ${ }^{\circ} 11.419$, de 19 de dezembro de 2006, viabilizou a informatização do processo judicial no âmbito de toda a Justiça Brasileira. Nos termos de seu artigo $1^{\circ}$, caput, "o uso de meio eletrônico na tramitação de processos judiciais, comunicação de atos e transmissão de peças processuais será admitido nos termos desta Lei.”

\footnotetext{
${ }^{9}$ Na Justiça Comum (Justiça Estadual, Justiça do Distrito Federal e Justiça Federal), em primeiro grau os Juízes (aqueles que julgam os processos, exercendo a tutela jurisdicional) são chamados de Juízes de Direito (Justiça Estadual e do Distrito Federal) e Juízes Federais (Justiça Federal); nos Tribunais são chamados Desembargadores (Justiça Estadual e do Distrito Federal) e Desembargadores Federais (Justiça Federal); no STJ e no STF são chamados Ministros.
} 
Diante disso, torna-se possível, com base no referido dispositivo legal, conceituar o processo judicial eletrônico como o processo judicial que utiliza o meio eletrônico para a sua tramitação, comunicação de atos e transmissão de peças processuais.

O mesmo artigo, em seu parágrafo $2^{\circ}$, define, outrossim, meio eletrônico e transmissão eletrônica.

$\S 2^{\circ}$ Para o disposto nesta Lei, considera-se:

I - meio eletrônico qualquer forma de armazenamento ou tráfego de documentos e arquivos digitais;

II - transmissão eletrônica toda forma de comunicação a distância com a utilização de redes de comunicação, preferencialmente a rede mundial de computadores;

(...). 


\section{PROCESSO JUDICIAL E INFORMATIZAÇÃO}

\subsection{A informatização do processo judicial antes da Lei n. $^{\circ}$ 11.419/2006}

Se por um lado é inegável que a Lei $n .^{\circ}$ 11.419/2006 foi um grande avanço da legislação positiva brasileira em termos de modernização do processo judicial, por outro é inequívoco que a informatização do processo judicial teve seu início antes de seu advento.

O avanço da tecnologia e a disseminação do computador permitiram a sua utilização pelo Poder Judiciário para armazenar dados relativos aos processos e seus respectivos trâmites, como o armazenamento de fases etc.

Aplicativos como o Microsoft Office permitiram a substituição das antigas máquinas de escrever pelos computadores no desempenho de tarefas que consistiam na elaboração de documentos expedidos pelo Poder Judiciário, como mandados de intimação, citação, busca e apreensão, editais, despachos, decisões, sentenças, acórdãos etc.

As facilidades advindas da utilização do computador para a confecção dos mencionados documentos foram inúmeras e, dentre elas, pode-se destacar a diminuição do tempo gasto para a sua elaboração, graças à utilização de modelos pré-existentes; a facilidade de correção dos documentos criados; a otimização das pesquisas sobre os mesmos documentos que deixaram de ser manuais para serem realizadas por meio do computador; e a segurança no arquivamento dos mesmos.

Da mesma forma, as audiências em primeiro grau de jurisdição puderam ser realizadas através do uso do computador, o que veio facilitar em grande escala a coleta dos dados das partes e testemunhas ouvidas. 
No Superior Tribunal de Justiça, utiliza-se o "Sistema Justiça" para a tramitação processual na Corte. O Sistema Justiça é composto de vários módulos, os quais são utilizados para o lançamento de fases relativas à tramitação do processo e que podem ser visualizadas pela internet em tempo real; para a criação de documentos, utilizando modelos préconcebidos e já certificados; para a elaboração de provimentos jurisdicionais de toda espécie; para consultas processuais, dentre outros.

Segundo Benucci (2007, pp. 90-110), a virtualização do processo teve seu início não com o advento da Lei n. ${ }^{\circ} 11.419 / 2006$, mas sim com a popularização e difusão dos computadores e programas no mundo e especificamente no Poder Judiciário.

Apesar do avanço da tecnologia e da informática em todos os meios, o Brasil ainda caminha a passos lentos em termos de modernização da máquina pública.

Em 30/08/2006, foi divulgada uma pesquisa no site <www.processoeletronico.com.br>, coordenada pelo Dr. José Carlos de Araújo Almeida Filho, então Presidente do Instituto Brasileiro de Direito Eletrônico, sobre o nível de informatização dos Tribunais de Justiça de todos os estados da Federação, no que se refere aos processos judiciais. A pesquisa levou em consideração dois aspectos: 1) se o respectivo Tribunal disponibilizava algum sistema eletrônico para consulta ou publicação das decisões judiciais, que pudessem ser acessados e consultados por meio da internet, diários de justiça eletrônicos, onde as decisões pudessem ser publicadas, dentre outros; e 2) se havia possibilidade de peticionamento eletrônico por meio do site do Tribunal na internet. O quadro 1 traz o resultado da pesquisa:

\begin{tabular}{|l|l|l|}
\hline Tribunal de Justiça & \multicolumn{1}{|c|}{ Sistema } & Peticionamento \\
\hline Acre & Consultas processuais & Não disponível \\
\hline
\end{tabular}




\begin{tabular}{|c|c|c|}
\hline Alagoas & Consultas e Bacen-Jud (sistema de penhora on-line) & Não disponível \\
\hline Amapá & Consultas processuais & Não disponível \\
\hline Amazonas & Consultas e documentação eletrônica & Não disponível \\
\hline Bahia & Consultas processuais, queixa prévia e diário eletrônico & Não disponível \\
\hline Ceará & Consultas processuais, diário eletrônico & Não disponível \\
\hline Distrito Federal e Territórios & $\begin{array}{l}\text { Consultas processuais, visualização de documentos } \\
\text { assinados digitalmente }\end{array}$ & Em fase de implementação \\
\hline Espírito Santo & Consultas processuais, diário eletrônico & Não disponível \\
\hline Goiás & Consultas processuais, diário eletrônico & Não disponível \\
\hline Maranhão & Consultas processuais, diário eletrônico & Não disponível \\
\hline Mato Grosso & Consultas processuais & Não disponível \\
\hline Mato Grosso do Sul & Fora do ar & Fora do ar \\
\hline Minas Gerais & Consultas processuais & Não disponível \\
\hline Pará & $\begin{array}{l}\text { Consultas processuais, autenticidade de certidões, sessões } \\
\text { ao vivo do Tribunal do Júri }\end{array}$ & Não disponível \\
\hline Paraíba & Consultas processuais, sistema telejudiciário & Não disponível \\
\hline Paraná & $\begin{array}{l}\text { Consultas processuais, Bacen-jud, diversos serviços } \\
\text { disponíveis }\end{array}$ & Possível - admite-se \\
\hline Pernambuco & Consultas processuais & $\begin{array}{l}\text { Prejudicado, diante da falta de } \\
\text { acessibilidade do portal }\end{array}$ \\
\hline Piauí & Consultas processuais & Não disponível \\
\hline Rio de Janeiro & Consultas processuais & $\begin{array}{l}\text { Disponível, mas com a entrega do } \\
\text { original em } 05 \text { dias }\end{array}$ \\
\hline Rio Grande do Norte & Consultas processuais & Não disponível \\
\hline Rio Grande do Sul & $\begin{array}{l}\text { Diversos serviços informatizados, incluindo assinatura } \\
\text { digital }\end{array}$ & Não disponível \\
\hline Rondônia & Consultas processuais & Não disponível \\
\hline Roraima & Consultas processuais, diário eletrônico & Não disponível \\
\hline Santa Catarina & Consultas processuais, diário eletrônico & Não disponível \\
\hline São Paulo & Consultas Processuais, diário eletrônico & Não disponível \\
\hline
\end{tabular}

Quadro 1: resultado de pesquisa sobre a informatização dos Tribunais de Justiça no Brasil. Fonte: site Processo Eletrônico. Disponível em: <www.processoeletronico.com.br.>.Acesso em 25 jan. 2009.

Dos 25 Tribunais que tiveram seus sites eletrônicos analisados, somente um não pôde ter constatada a possibilidade de consultas processuais por meio da internet, pois estava fora 
do ar. Todos os demais possibilitavam esse tipo de consulta, conforme se observa no gráfico 4.

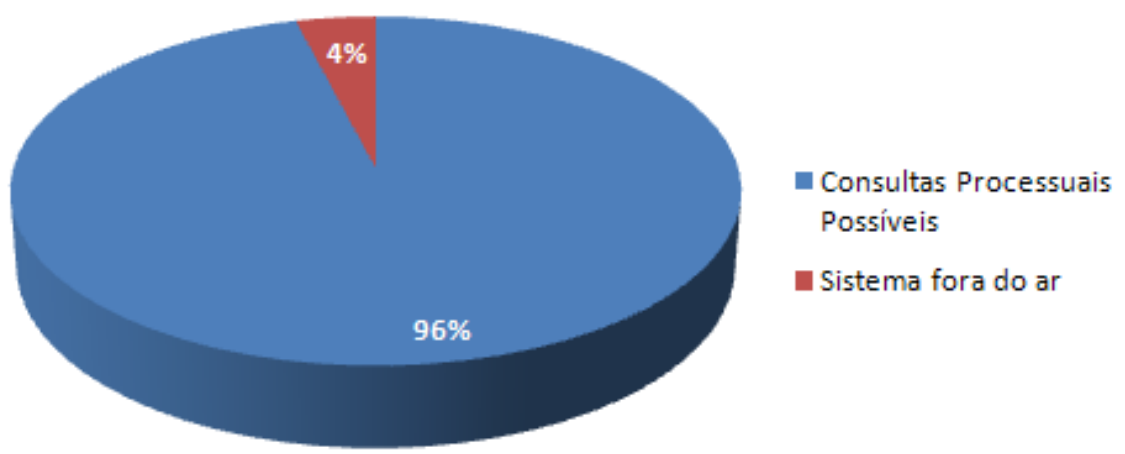

Gráfico 4: Tribunais de Justiça que disponibilizam consultas processuais pela Internet.

Fonte: Elaborado pelo autor, com base nos dados constantes da Quadro 1.

Desconsiderando o Tribunal de Justiça do Mato Grosso do Sul, cujo website estava fora do ar, apenas 8 dos 24 Tribunais restantes disponibilizam o serviço de Diário de Justiça Eletrônico, conforme se verifica do Gráfico 5:

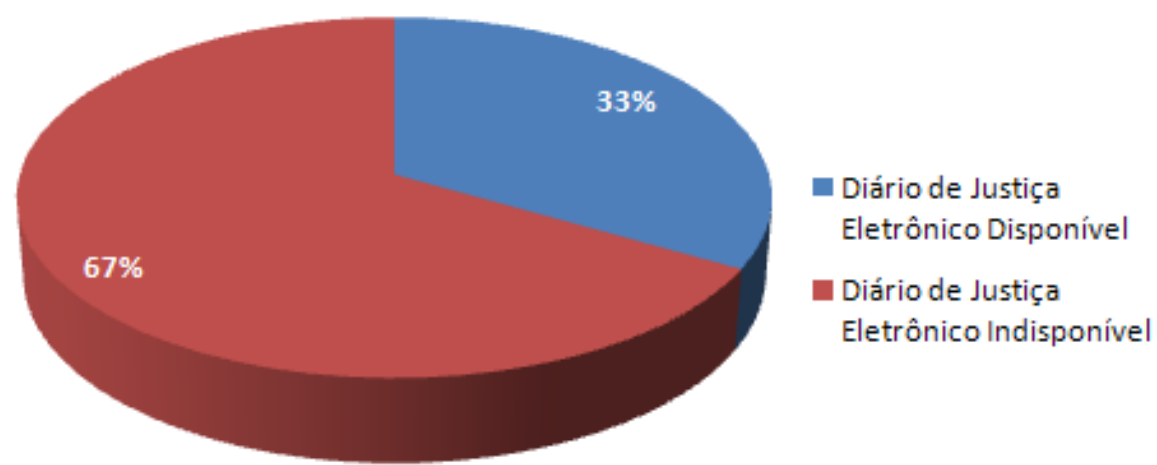

Gráfico 5: Tribunais de Justiça que disponibilizam Diário de Justiça Eletrônico.

Fonte: Elaborado pelo autor, com base nos dados constantes da Quadro 1. 
Por fim, de acordo com o Gráfico 6, observa-se que a petição eletrônica, quando da pesquisa e excetuando-se o TJMS, era realidade plena em apenas um Tribunal (TJPR), de aplicação limitada em outro (TJRJ) e inexistente em todos os demais.
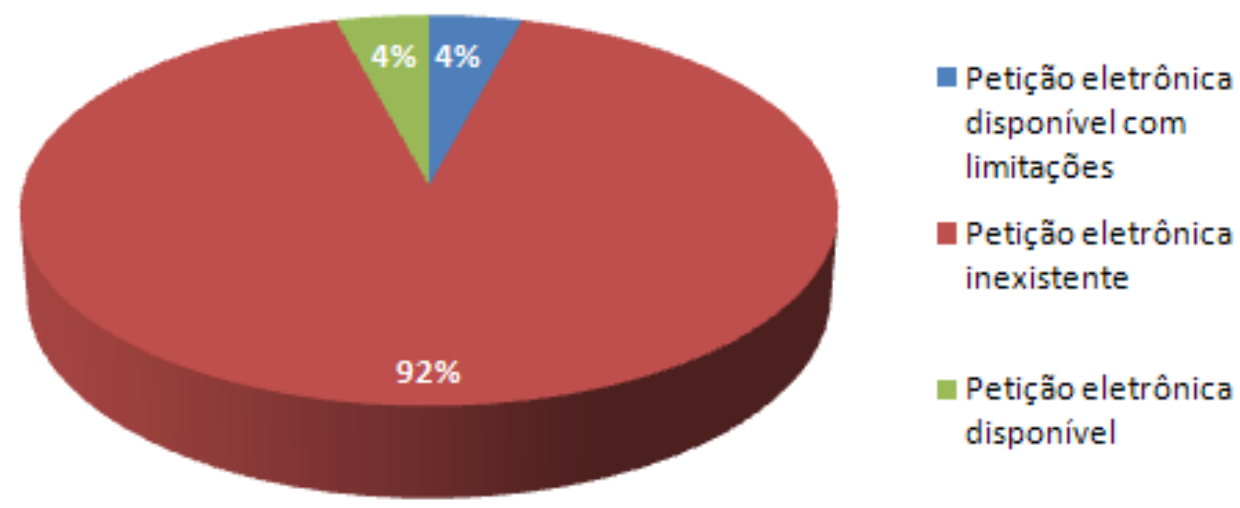

Gráfico 6: Tribunais de Justiça avaliados que disponibilizam o uso da petição eletrônica.

Fonte: Elaborado pelo autor, com base nos dados constantes do Quadro 1.

\subsection{Histórico da legislação brasileira no tocante à modernização do processo judicial}

A Lei ${ }^{\circ}{ }^{\circ} 8.245$ de 18 de outubro de 1991, conhecida como Lei do Inquilinato, inovou a legislação brasileira ao permitir a comunicação de atos processuais, nos termos de seu art. 58, IV:

Art. 58. Ressalvados os casos previstos no parágrafo único do art. $1^{\circ}$, nas ações de despejo, consignação em pagamento de aluguel e acessório da locação, revisionais de aluguel e renovatórias de locação, observar - se - á o seguinte:

(...).

IV - desde que autorizado no contrato, a citação, intimação ou notificação far - se - á mediante correspondência com aviso de recebimento, ou, tratando - se de pessoa jurídica ou firma individual, também mediante telex ou fac-símile, ou, ainda, sendo necessário, pelas demais formas previstas no Código de Processo Civil;

(...). 
Oito anos mais tarde, foi promulgada a Lei n. ${ }^{\circ} 9.800$ de 26 de maio de 1999 , que veio permitir a prática de diversos atos processuais por meio de fax, incluindo o encaminhamento de petições de recursos pelas partes. O encaminhamento de petições via fax e sua validade, desde que preenchidos os requisitos dispostos na referida lei podem ser considerados precursores da petição eletrônica.

Reinaldo Filho (2007), faz as seguintes ponderações sobre a importância da Lei do Fax para a modernização do processo judicial:

\begin{abstract}
O que a Lei 9.800/99 possibilitou foi apenas um trânsito de petições em meio eletrônico, as quais, chegando aos provedores informáticos dos tribunais, eram impressas em papel e anexadas ao processo físico. A forma física (da peça processual) não era abandonada até porque essa Lei não dispensava as partes de entregar os originais (entenda-se: documento em meio físico) até 05 dias da data do término do prazo (art. $2^{\circ}$.). Além disso, a Lei $9.800 / 99$ possibilitou a prática de ato processual específico - a transmissão de petições por meio eletrônico (excluídos, portanto, outros atos, tais como aqueles próprios da audiência).
\end{abstract}

Em 12 de julho de 2001 foi promulgada a Lei $n .^{\circ} 10.259$, que instituiu no âmbito da Justiça Federal os Juizados Especiais. Esta lei trouxe pelo menos três dispositivos que tiveram importância singular na modernização do processo judicial.

Segundo o autor, o art. $8^{\circ}, \S 2^{\circ}$ permitiu o desenvolvimento de sistemas informatizados para a recepção de peças processuais - sem exigência semelhante à da Lei n. ${ }^{\circ}$ 9.800/99, quanto à apresentação subseqüente de originais em meio físico, autorizando ainda a organização de serviços eletrônicos de comunicação de atos processuais. $\mathrm{O}$ art. $14, \S 3^{\mathrm{O}}$ estabeleceu que "as reuniões de juízes integrantes da Turma de Uniformização jurisprudencial, quando domiciliados em cidades diferentes, deve ser feita por via eletrônica". $\mathrm{O}$ art. 24 da mencionada lei impulsionou a criação e aprimoramento de softwares aptos a subsidiar a instrução das causas. 
No mesmo ano de 2001, foi promulgada ainda a Lei $\mathrm{n}^{\circ}$ 10.358, que alterou dispositivos do Código de Processo Civil, relativos ao processo de conhecimento. A alteração relativa ao parágrafo único do art. 154 do CPC foi vetada, pelo então Presidente da República Fernando Henrique Cardoso.

Eis o dispositivo vetado:

Atendidos os requisitos de segurança e autenticidade, poderão os tribunais disciplinar, no âmbito da sua jurisdição, a prática de atos processuais e sua comunicação às partes, mediante a utilização de meios eletrônicos

No entanto, o parágrafo único do art. 154 do CPC foi, reintroduzido pela Lei n. ${ }^{\circ}$ 11.280 de 16 de fevereiro de 2006, com a nova redação a seguir:

\footnotetext{
Art. $154(\ldots)$

Parágrafo Único. Os tribunais, no âmbito da respectiva jurisdição, poderão disciplinar a prática e a comunicação oficial dos atos processuais por meios eletrônicos, atendidos os requisitos de autenticidade, integridade, validade jurídica e interoperabilidade da Infra-Estrutura de Chaves Públicas Brasileira - ICP - Brasil.
}

Ainda em 2006, o art. 541 do CPC ganhou nova redação com a Lei n. ${ }^{0} 11.341$ de 7 de agosto, que permitiu aos recorrentes em recursos especiais e extraordinários, fundados em dissídios jurisprudenciais, realizar o cotejo analítico para provar a divergência alegada por meio de provimentos jurisdicionais disponíveis em mídia eletrônica, inclusive reproduzidos na internet em repositórios oficiais.

No mesmo ano, houve a alteração de vários dispositivos do Código de Processo Civil, concernentes ao processo de execução por título extra-judicial, por meio da Lei n. ${ }^{\circ} 11.382$ de 6 de dezembro de 2006. Com a mencionada lei, foram criados os institutos da penhora on line (art. 655-A) e do leilão on line (art. 689-A). 
De notável importância, todas as leis mencionadas para a modernização do processo judicial. No entanto, o estabelecimento definitivo do processo eletrônico somente se daria com a Lei.$^{\circ}$ 11.419/2006.

\title{
5.3 A Lei n. ${ }^{\circ} 11.419$ de 19 de dezembro de 2006
}

\subsubsection{Histórico}

A Lei n. ${ }^{\circ} 11.419 / 06$, que dispõe sobre a informatização do processo judicial, teve origem no Projeto de Lei n. ${ }^{\circ}$ 5.828/01, aprovado pelo Plenário da Câmara dos Deputados em 30 de novembro do mesmo ano. Foi o projeto aprovado como substitutivo proposto pelo Senado Federal, com emendas de redação devidamente aprovadas pela CCJC - Comissão de Constituição e Justiça e Cidadania.

Sobre as expectativas criadas no Poder Judiciário pela aprovação da mencionada lei,

Reinaldo Filho (2007) destaca:

\begin{abstract}
Uma das autoridades judiciárias que se mostraram mais entusiasmadas com a publicação da Lei foi o Presidente do Superior Tribunal de Justiça, Ministro Raphael de Barros Monteiro Filho. "Esta lei é de muita relevância para o Poder Judiciário porque vai estabelecer, vai criar, o processo digital, que na verdade é uma quebra de paradigma do Poder Judiciário", afirmou o Ministro. Para ele, o processo virtual ou eletrônico acabará rompendo as resistências naturais da sociedade civil, e até mesmo, de alguns julgadores. "Temos certeza de que o legislador, com a edição da lei 11.419, está justamente atendendo à premente necessidade de que o processo tenha uma tramitação mais ágil", acredita o Presidente. Espera-se realmente que, com a edição da nova Lei, a Justiça finalmente ingresse no século XXI, mais próxima do cidadão e mais ágil na prestação jurisdicional.
\end{abstract}

No entanto, o caminho trilhado pelo projeto de lei até sua aprovação foi árduo e tortuoso. 
O Projeto de Lei n. ${ }^{\circ}$ 5828/01 originou-se de uma proposta da Associação dos Juízes Federais do Brasil (AJUFE), acolhida e ratificada pela Comissão de Participação Legislativa da Câmara no mesmo ano, oportunidade em que recebeu parecer favorável do Deputado Federal Ney Lopes. Em 04/12/2001 foi o projeto lido e apresentado no Plenário da Câmara dos Deputados pela Comissão de Legislação Participativa.

Recebido na Comissão de Constituição e Justiça e de Cidadania (CCJC), em 26/02/2002, foi designado relator do projeto o Deputado Federal Roberto Batochio em abril do mesmo ano. Em 22/05/2002 o relator apresentou parecer pela constitucionalidade, juridicidade e técnica legislativa, e, no mérito, pela aprovação. $\mathrm{O}$ projeto foi aprovado à unanimidade na Comissão em 11/06/2002.

Em 19/06/2002, foi o projeto aprovado pelo Plenário da Câmara dos Deputados e encaminhado ao Senado Federal. No Senado, o projeto recebeu a sigla PLC 71/2002, obtendo, igualmente, parecer favorável pela sua aprovação em 1\%11/2005, no entanto, em forma de substitutivo pela relatora, a Senadora Serys Slhessarenko, aprovado pela Comissão de Constituição, Justiça e Cidadania do Senado na mesma data. O substitutivo foi aprovado no plenário do Senado em 07/12/2005.

Em virtude dos cinco anos decorridos desde a propositura do projeto original na Câmara dos Deputados até a aprovação do substitutivo no Senado Federal, o seu texto foi substancialmente alterado, sob a justificativa da última relatora de que a evolução tecnológica do período exigia essa atualização. A possibilidade de utilização de um Diário de Justiça on line, ou Diário Eletrônico, bem como a certificação digital por autoridade certificadora credenciada e não só por cadastro no próprio Poder Judiciário então os avanços implementados no substitutivo do Senado Federal. 
Devidamente aprovado o substitutivo no Plenário do Senado, o projeto retornou à Câmara dos Deputados, sendo recebido na Comissão de Constituição Justiça e Cidadania em 5/01/06. Em 9/01/06 foi designado relator o Deputado Federal José Eduardo Cardozo, que apresentou seu parecer favorável à aprovação do projeto em 29/06/2006. No dia 4/07/2006, o parecer foi aprovado pela CCJC.

Por fim, em 30 de novembro de 2006, foi o substitutivo do Senado Federal aprovado no Plenário da Câmara, se tornando então a Lei n. ${ }^{\circ}$ 11.419/2006, a qual foi sancionada pelo Presidente da República, com veto parcial, em 19 de dezembro daquele ano.

\subsubsection{A informatização do processo judicial segundo a Lei n..$^{\circ}$ 11.419/2006}

O Capítulo I da Lei n. ${ }^{\circ}$ 11.419/2006, com o título "Da Informatização do Processo Judicial”, abrange os três primeiros artigos daquela.

$\mathrm{O}$ art. $1^{\circ}$, caput, é claro ao descrever a finalidade da lei: "O uso de meio eletrônico na tramitação de processos judiciais, comunicação de atos e transmissão de peças processuais será admitido nos termos desta Lei”. Portanto, essa lei não criou a possibilidade de utilização de meios eletrônicos nos processos judiciais. Na verdade, o início destas práticas se deu com a própria difusão da informática no Brasil e sua absorção pelo Poder Judiciário. No entanto, a lei sob estudo trouxe avanços substanciais para a informatização do processo judicial.

O âmbito de abrangência da lei é bastante vasto, eis por se aplicar aos processos civil, penal e trabalhista, aos juizados especiais, em qualquer grau de jurisdição $\left(\S 1^{\circ}\right.$, do art. $\left.1^{\circ}\right)$. Em resumo, pode-se afirmar que a presente lei é aplicável a todo o Poder Judiciário Brasileiro, contemplando a Justiça comum: Justiça dos Estados, do DF e Territórios e Federal; e às Justiças especializadas: Justiças Trabalhista, Militar e Eleitoral. Ambos os graus de 
jurisdição também estão contemplados, desde o primeiro e o segundo graus, até as instâncias especiais (Tribunais Superiores) e extraordinária (Supremo).

Almeida Filho (2007, p. 192) faz algumas observações pertinentes sobre os efeitos do mencionado parágrafo em cada uma das especialidades contempladas:

Ocorre, contudo, que há peculiaridades em cada processo. O processo civil se apresenta ainda formal, se bem que modernas teorias acerca da instrumentalidade das formas vêm mitigando este rigor e procurando aproveitar, ao máximo, os atos praticados no processo. Quanto ao processo do trabalho, de natureza especialíssima, o primeiro contato do juiz com os autos se dá na audiência de conciliação, que poderá ser convolada em instrução e julgamento. Finalmente, quanto ao processo penal, é previsto que as garantias fundamentais sejam preservadas.

Desta forma, apesar de se estar diante de uma lei aplicável às três modalidades de processo - civil, penal e trabalhista - os desdobramentos da mesma em cada um dos ritos deverá possuir situações próprias, com o escopo de satisfazer as peculiaridades dos mesmos.

O parágrafo $2^{\circ}$ do art. $1^{\circ}$ conceitua meio eletrônico e transmissão eletrônica para os fins da lei, com o objetivo de extirpar qualquer dúvida quanto à sua utilização e finalidade. Estabelece ainda que a assinatura eletrônica poderá ter duas formas distintas de identificação inequívoca do signatário: 1) assinatura digital baseada em certificado digital emitido por Autoridade Certificadora credenciada, na forma de lei específica; e 2) mediante cadastro de usuário no Poder Judiciário, conforme disciplinado pelos respectivos órgãos.

No projeto de lei originário (PL n. ${ }^{\circ}$ 5.828), apresentado no Plenário da Câmara dos Deputados em 2001, não estava contemplada a primeira hipótese mencionada. Segundo aquele, somente seria possível a utilização de assinatura eletrônica, mediante cadastro do usuário no Poder Judiciário. O projeto de lei substitutivo (PLC n. ${ }^{\circ}$ 71/2002) cujo parecer, com modificações, foi apresentado pela Senadora Serys Slhessarenko em 2005, trouxe em seu bojo a primeira hipótese, que se tornou então parte integrante da lei. 
$\mathrm{O}$ art. $2^{\circ}$ trata da petição por meio eletrônico:

O envio de petições, de recursos e a prática de atos processuais em geral por meio eletrônico serão admitidos mediante uso de assinatura eletrônica, na forma do art. $1^{\circ}$ desta Lei, sendo obrigatório o credenciamento prévio no Poder Judiciário, conforme disciplinado pelos órgãos respectivos.

É importante observar que há duas formas possíveis para obter a assinatura eletrônica. Entretanto, independentemente do meio escolhido, é necessário o credenciamento prévio da parte ou terceiro interessado no Poder Judiciário para o envio de petições, recursos e a prática dos atos processuais por meio eletrônico.

Os parágrafos do art. $2^{\circ}$, por seu turno, disciplinam a forma com que tal credenciamento deverá ser feito. Importante ainda notar a possibilidade de o Poder Judiciário criar um cadastro único para o credenciamento previsto no artigo $\left(\S 3^{\circ}\right)$, o que unificaria o sistema, tornando-o mais eficiente, acessível e cristalino.

Esse cadastro terá como ponto de partida para sua criação, a Resolução n. ${ }^{\circ} 65$ de 16 de dezembro de 2008, do Conselho Nacional de Justiça, que "dispõe sobre a uniformização do número dos processos nos órgãos do Poder Judiciário e dá outras providências.”

$\mathrm{Na}$ atualidade, cada processo no Poder Judiciário possui um número e cada Tribunal do País e órgãos a eles vinculados possuem uma numeração própria. Nos termos da resolução do Conselho Nacional de Justiça, a numeração dos processos no Poder Judiciário nacional será única e utilizada por todos os órgãos Judiciários do país.

Essa iniciativa facilitará o cadastro das partes e advogados para o envio de documentos eletrônicos uma vez que possibilita que esse cadastro também seja único.

$\mathrm{O}$ art. $3^{\circ}$ estabelece que o horário e a data da prática do ato processual será o do seu envio ao sistema do Poder Judiciário, mediante o fornecimento de protocolo eletrônico. Já seu 
parágrafo único, acarretará uma profunda alteração na prática cartorária forense, possibilitando o envio da petição eletrônica em qualquer hora do dia sendo consideradas "tempestivas as transmitidas até as 24 horas do seu último dia".

O novo entendimento, veio ampliar o entendimento anterior quanto ao tema, estatuído na redação do art. 172 do Código de Processo Civil, segundo o qual "os atos processuais realizar-se-ão em dias úteis, das 6 às 20 horas".

Especificamente no tocante ao protocolo de petições, a doutrina, antes mesmo do advento da lei em análise, já entendia que o prazo deveria ser mitigado, conforme assevera Theodoro Júnior (2001, p. 210):

\footnotetext{
Observe-se, ainda, que o horário útil para protocolar petições não é o genérico do caput do art. 172, onde se prevê a eventualidade de atos processuais até às 20 horas. Quando o recurso ou outro ato depender de protocolo, o que fixa o momento final de sua possibilidade é o término do expediente assinalado pela lei de organização judiciária.
}

Mesmo adotando-se o entendimento supra, não seria razoável pensar em cartórios judiciais que trabalhassem 24 horas recebendo petições. Se houvesse alterações no expediente, ampliando o horário estabelecido no art. 172, não seriam esses tão significativos, pela própria inviabilidade de se manter um Tribunal ou Fórum funcionando ininterruptamente, salvo sob regime de plantão forense.

No entanto, parágrafo único do art. $3^{\circ}$ possibilita ao advogado, parte ou interessado o protocolo de petições a qualquer hora do dia, 7 dias por semana, sendo considerada a mesma tempestiva se transmitida até as 24 horas do último dia.

O Capítulo II, que vai do art. $4^{\circ}$ ao art. $7^{\circ}$, trata da Comunicação Eletrônica dos Atos Processuais. $\mathrm{O}$ art. $4^{\circ}$ aborda especificamente o Diário de Justiça Eletrônico, que deverá ser 
disponibilizado necessariamente na internet, sendo nele publicados os atos judiciais e administrativos próprios dos órgãos a eles subordinados, além de outras comunicações.

O Diário da Justiça Eletrônico é o sucessor do Diário da Justiça, apresentado em papel, utilizado ainda por muitos órgãos do Poder Judiciário e publicado pela imprensa oficial. No caso da Justiça Federal, dos Tribunais Superiores e do Supremo Tribunal Federal, as publicações relativas à provimentos jurisdicionais, antes da implementação do Diário da Justiça Eletrônico eram, e ainda são em alguns casos, feitas pela Imprensa Nacional, através do Diário da Justiça da União.

As peculiaridades e exigências referentes ao Diário da Justiça Eletrônico vêm disciplinadas nos parágrafos do art. $4^{\circ}$. Dentre elas, pode-se destacar a necessidade de assinatura digital para as publicações; regras relativas à contagem do prazo processual e a necessidade de ampla divulgação do mencionado diário, para que esse possa entrar em uso.

Os artigos $5^{\circ}$ e $6^{\circ}$ disciplinam as intimações e citações por meio eletrônico, que poderão ser dirigidas inclusive à Fazenda Pública. Segundo a nova regulamentação, não haverá mais a necessidade de envio de papéis, como informações, petições iniciais, por meio do sistema de correios ou de Oficial de Justiça, sendo que até mesmo as intimações pessoais e citações poderão ser realizadas pelo meio eletrônico.

As comunicações entre os diversos órgãos do Poder Judiciário nacional e internacional, realizados por meio de cartas precatórias e de ordem, no primeiro caso, e rogatórias no último, também deverão ser realizadas preferencialmente pelos meios eletrônicos, segundo o art. $7^{\circ}$.

O Capítulo III trata exclusivamente do Processo Eletrônico, e vai dos arts. $8^{\circ}$ ao 13. 
Almeida Filho (2007, p. 176) entende que a terminologia "Processo Eletrônico" está equivocada, uma vez que as regras inseridas na lei sob análise são se natureza procedimental. Segundo o autor "o que temos é procedimento", por ser a norma "meramente procedimental".

Feita essa observação, o processo eletrônico pode ser conceituado como o emaranhado de ritos e procedimentos, antes realizados mediante a utilização do papel e outros meios materiais e, agora, através de informações armazenadas em meio digital. Os documentos que antes formavam o que conhecemos como autos, serão no processo eletrônico bits de computador.

Pasa (2001, p. 75) discorre sobre o documento eletrônico:

(...) o papel não é o único suporte material possível do documento e, em conseqüência, a forma e os símbolos utilizados para reproduzir o pensamento humano. Assim, a fixação da informação poderá ser, por exemplo, em discos ópticos, ou seja, no meio digital. Em decorrência, o símbolo pode ser constituído de elementos básicos da informação eletrônica, como por exemplo bits. Pode-se conceituar o documento eletrônico como o documento que tem suporte material em meio eletrônico.

Os Tribunais poderão desenvolver sistemas capazes de permitir o processamento de ações utilizando autos digitais, de forma total ou parcial. A Internet deve ser utilizada preferencialmente (art. $4^{\circ}$, caput). Segundo o parágrafo único do mesmo artigo, qualquer ato praticado deve ser sempre precedido de assinatura eletrônica e deve estar em conformidade com o disposto na lei.

As citações e intimações no processo eletrônico estão disciplinadas no art. $9^{\circ}$ e seus parágrafos. Aqui valem as mesmas observações apresentadas aos arts. $5^{\circ}$ e $6^{\circ}$ da lei.

No entanto, fica a ressalva de que, diferentemente da intimação, que é ato rotineiro do Poder Judiciário por meio do qual se dá ciência às partes, interessados e Ministério Público de atos ocorridos e que ainda ocorrerão no processo; a citação, se constitui num dos atos processuais mais relevantes. Segundo Nunes (2003, p. 115), "é o ato pelo qual se chama a 
juízo o réu ou o interessado a fim de se defender". É com a citação válida que se forma a relação processual, sendo que quando essa é invalida, tem-se um "ato absolutamente nulo" (THEODORO JÚNIOR, 2001, p. 251).

Almeida Filho (2007, p. 265), levando em consideração a importância do ato da citação, manifesta sua preocupação com a realização da citação por meio eletrônico:

\begin{abstract}
Entendemos ser de bom alvitre que as citações sejam realizadas pelos meios ordinários. Não somente em termos de problemas técnicos, mas em virtude da possibilidade de interceptação de dados de telemática - o que configura crime, nos termos da Lei n. ${ }^{\circ}$ 9296/96, em seu art. 10.

Reprisamos a importância da citação no Processo Eletrônico e a possibilidade de os sistemas dos jurisdicionados (usuários) serem incompatíveis com os dos Tribunais (servidores). A possibilidade de utilização do software livre, que é previsto na legislação não suplanta as incompatibilidades entre os mais diversos sistemas operacionais em uso no Brasil. Há navegadores que não suportam leitura de determinadas imagens, como a que contem extensão .TIF, por exemplo.

A questão posta diz respeito ao acesso à Justiça e para que tal ocorra, é preciso que as normas estejam adequadas a uma realidade nacional.

O momento ainda é prematuro para debates sobre estas questões, mas podemos profeciar que situações atinentes às citações serão suscitadas nos Tribunais com grande freqüência. Os hacker's, kracker's e os lammer's não pouparão esforços no sentido de interceptarem comunicações entre os Tribunais e o citando. Isto sem considerar que a mensagem poderá não chegar ao destinatário por motivos diversos dos ataques, como a mudança de correio eletrônico ou indisponibilidade do sistema.
\end{abstract}

Se por um lado, deve ser levada em consideração a importância do ato da citação e os prejuízos para os litigantes (ao menos para um deles) e para o Poder Judiciário decorrentes de uma citação nula; por outro simplesmente abandonar a citação por meio eletrônico, na atual etapa, seria impedir a informatização plena do processo judicial. O equilíbrio, a cautela e o bom senso devem prevalecer sempre no sentido de garantir a devida segurança, sem impedir, o fluxo natural do processo pela via eletrônica.

A distribuição da petição inicial, bem como a juntada de outras peças aos autos (contestação, recursos etc) se dará por meio digital, diretamente pelas partes ou advogados no processo (art. 10, caput). Dispensa-se desta forma, a atividade de Secretaria consistente na juntada dos documentos aos autos físicos, o que trará grande celeridade ao trâmite processual. 
O prazo para a juntada de qualquer documento será até às 24 horas do último dia, sendo que, se o sistema estiver indisponível por qualquer motivo, fica o prazo prorrogado para o próximo dia útil (art. $\left.10, \S \S 1^{\circ} \mathrm{e} 2^{\circ}\right)$.

Para que seja possível às partes cumprir o disposto no caput do art. 10, as peças processuais deverão ser elaboradas em meio eletrônico, ou em meio físico e posteriormente digitalizadas, transformando-se em documentos digitais. A aquisição de computadores e digitalizadores, poderia impedir o acesso do cidadão à justiça, por motivos financeiros ou outros, violando desta forma o princípio da inafastabilidade da Jurisdição consagrado no art. $5^{\circ}, \mathrm{XXXV}$, da Constituição Federal, segundo o qual "a lei não excluirá da apreciação do Poder Judiciário nenhuma lesão ou ameaça de lesão a direito".

Para evitar qualquer prejuízo aos litigantes, “os órgãos do Poder Judiciário deverão manter equipamentos de digitalização e de acesso à rede mundial de computadores para a distribuição das peças processuais" (art. 10, $\S 3^{\circ}$ ). Essa medida é considerada "altamente salutar" por Almeida Filho (2007, p. 271).

$\mathrm{O}$ art. 11 considera como originais os documentos produzidos eletronicamente e juntados ao processo pelos órgãos do Poder Judiciário, Auxiliares da Justiça, partes e advogados, sendo que os extratos dos mesmos têm a mesma força probante daqueles $\left(\S 1^{\circ}\right)$. Eventual argüição de falsidade deverá ser processada em apartado, em autos também eletrônicos $\left(\S 2^{\circ}\right)$; e os originais dos documentos digitalizados devem ser guardados pelos seus proprietários até o trânsito em julgado da ação ou, quando admitida, até o prazo final para a interposição de ação rescisória.

Se eventualmente for inviável, pelo grande volume, a digitalização de documentos que acompanham a petição eletrônica, deverão ser os mesmos encaminhados ao respectivo órgão 
judiciário no prazo de dez dias do envio da petição eletrônica. Esses documentos serão devolvidos a quem de direito após o trânsito em julgado $\left(\S 5^{\circ}\right)$.

A publicidade dos documentos digitalizados juntados no processo eletrônico será restrita, dependendo de onde a fonte for acessada. Estarão acessíveis mediante rede externa somente às partes processuais e ao Ministério Público, respeitadas ainda as situações de sigilo e de segredo de justiça $\left(\S 5^{\circ}\right)$.

A Constituição Federal, no seu art. $5^{\circ}$, XXXIII, estatui que:

Todos têm direito a receber dos órgãos públicos informações de seu interesse particular, ou de interesse coletivo ou geral, que serão prestadas no prazo da lei, sob pena de responsabilidade, ressalvadas aquelas cujo sigilo seja imprescindível à segurança da sociedade e do estado.

Em se tratando de processo judicial físico, conforme o disposto do inciso XXXIII, do art. $5^{\circ}$, qualquer pessoa poderá, a princípio, solicitar cópia do mesmo no respectivo órgão judiciário, desde que o processo não seja sigiloso ou esteja em segredo de justiça. Quanto aos processos sigilosos e em segredo de justiça, somente terão acesso aos mesmos as partes litigantes; e os órgãos públicos e auxiliares da justiça que neles estejam atuando.

Tal determinação foi corroborada pela lei no que se refere ao processo eletrônico. Qualquer parte do processo e o Ministério Público terão acesso aos documentos juntados em qualquer local, bastando para tanto acessar o sistema por meio da rede mundial de computadores. No entanto, o disposto no $\S 6^{\circ}$ do art. 11 não impede que as partes interessadas continuem solicitando cópias desses documentos diretamente no respectivo órgão judiciário, ressalvadas as hipóteses de segredo de justiça e processos sigilosos. 
O art. 12 trata da conservação dos autos, estabelecendo que esta poderá se dar total ou parcialmente por meio eletrônico. A conservação dos autos eletrônicos dispensa a formação de autos suplementares exige que todas as medidas de segurança sejam tomadas para que sejam esses preservados e acessados sempre que necessário $\left(\S 1^{\circ}\right)$. Caso haja necessidade de remessa dos autos a Juízo ou Tribunal que não disponha de sistema compatível, esses deverão ser impressos e autuados nos termos dos arts. 166 a 168 do Código de Processo Civil, ainda que os mesmos sejam de natureza criminal, trabalhista ou de competência de juizado especial $\left(\S 2^{\circ}\right)$. Os autores e a Justiça de origem serão certificados do fato, pelo escrivão ou chefe de secretaria $\left(\S 3^{\circ}\right)$. Caso seja necessária a digitalização de autos em mídia não digital, deverá ser comunicada por meio de intimação (por edital ou pessoal) às partes ou seus procuradores, para que em 30 dias (prazo preclusivo), esses se manifestem "sobre o desejo de manterem pessoalmente a guarda de algum dos documentos originais".

Apesar de os autos se tornarem eletrônicos ou virtuais, "o processo seguirá a tramitação estabelecida para os processos físicos" (art. 12, § $4^{\circ}$ ). Por esse motivo é que Almeida Filho (2007, p. 176) considera equivocada a terminologia Processo Eletrônico, por tratar a presente lei de norma meramente procedimental, seguindo processo a mesma tramitação já existente.

Isso quer dizer que uma ação rescisória, por exemplo, apesar de estar contida em autos eletrônicos possuindo documentos digitais em sua integridade, continuará seguindo o rito da ação rescisória disciplinada pela lei processual. A Lei n. ${ }^{\circ}$ 11.419/2006 altera a forma com que o processo se apresenta - que migrará do físico para o digital - mas não o rito a ser seguido, que permanecerá de acordo com cada tipo de processo e com as leis processuais vigentes e com a Constituição Federal. 
A exibição de qualquer documento poderá ser realizada por meio eletrônico por determinação do Magistrado, bem como o envio dos mesmos para a instrução do processo (art. 13, caput). $\mathrm{O} \S 1^{\circ}$ define o que são cadastros públicos para o efeito desta lei e o $\S 2^{\circ}$ preceitua que "o acesso de que trata este artigo dar-se-á por qualquer meio tecnológico disponível, preferentemente o de menor custo, considerada sua eficiência"

O quarto é último capítulo da lei trata das disposições gerais e vai do art. 14 ao art. 22.

Os sistemas a serem desenvolvidos pelo Poder Judiciário para possibilitar a informatização do processo judicial e a criação do processo eletrônico deverão utilizar, preferencialmente, programas com código aberto e acessíveis 24 horas pela Internet, priorizando-se ainda sua padronização (art. 14).

Conforme mencionado, a Resolução n. ${ }^{\circ}$ 65/2008 do Conselho Nacional de Justiça, que unifica o sistema de numeração de processos em todo o Poder Judiciário do Brasil, é um significativo passo nessa direção. Os sistemas criados deverão identificar a ocorrência de prevenção, litispendência ou coisa julgada (art. 14, parágrafo único).

A prevenção ocorre quando determinado processo está relacionado com um processo anteriormente distribuído e, por isso deve ser distribuído para o mesmo Magistrado ao qual foi encaminhado o processo anterior. A litispendência ocorre quando determinado processo distribuído possui as mesmas partes, objeto, pedido e causa de pedir de um já anteriormente distribuído. É um "clone” de um processo pré-existente a ele. A coisa julgada ocorre com o trânsito em julgado material de uma ação. Desta forma, o mérito do que foi discutido no processo que transitou em julgado não pode ser novamente discutido em novo processo, com raras exceções como a ação rescisória e a revisão criminal. 
A identificação desses três fenômenos por parte do sistema informatizado busca evitar julgamentos divergentes nos dois primeiros casos e que uma questão definitivamente resolvida pelo Judiciário seja novamente apreciada.

O número do Cadastro de Pessoas Físicas $(\mathrm{CPF})$, obtido junto à Secretaria da Receita Federal, deverá ser informado quando da distribuição da petição inicial de qualquer ação judicial, salvo se o procedimento inviabilizar seu acesso à Justiça (art. 15, caput), como na hipótese da parte não possuir $\mathrm{CPF}$, pois esse fato não pode impedir o acesso da pessoa ao poder judiciário, em observância ao Princípio Constitucional da Inafastabilidade da Jurisdição $\left(\mathrm{CF}\right.$, art. $\left.5^{\circ}, \mathrm{XXXV}\right)$. Segundo o parágrafo único do mesmo artigo, as peças de acusação criminais deverão ser instruídas pelo Ministério Público, ou pelas autoridades policiais (Delegados de Polícia) com os números de registros dos acusados no Instituto Nacional de Identificação do Ministério da Justiça, se houver.Serão eletrônicos ainda os livros cartorários e repositórios do Poder Judiciário (art. 16), cabendo a esse poder, a regulamentação da presente lei, no âmbito de suas respectivas competências (art. 18). Os atos processuais eletrônicos praticados anteriormente à vigência desta lei ficam convalidados, se atingiram suas respectivas finalidades e desde que não tenha havido prejuízo às partes.

Por fim, o art. 20 altera os arts. 38, 154, 164, 169, 202, 221, 237, 365, 399, 417, $457 \mathrm{e}$ 556 do Código de Processo Civil, para viabilizar a informatização do processo judicial.

Quando da Sanção por parte do Presidente da República, foram vetados o $§ 4^{\circ}$, do art. 10 ; o $\S 3^{\circ}$ do art. 15; o art. 17; o art. 21; e as alterações no parágrafo único do art. 154 do Código de Processo Civil. 


\section{INSUMOS TECNOLÓGICOS NECESSÁRIOS À INFORMATIZAÇÃO DO PROCESSO JUDICIAL}

Para que a informatização do processo judicial seja plenamente efetivada, a Lei n. ${ }^{\circ}$ 11.419/06 exige uma série de insumos tecnológicos. Esses podem ser divididos em três grupos distintos: hardwares, softwares e insumos que dependem da utilização de hardwares e softwares para se realizarem.

\subsection{Hardware}

Santos (2005, p. 11) define o que é hardware:

É o conjunto de componentes elétricos eletrônicos e mecânicos que constituem a máquina. Podemos dizer que o hardware é a parte física do equipamento, é tudo aquilo que podemos tocar, pegar. Hardware é, então, a CPU, os dispositivos de entrada e saída (periféricos), as placas e seus barramentos, os dispositivos de memória e outros.

Os principais hardwares necessários para a implementação das disposições da referida lei são: o computador, impressoras, digitalizadores, servidores para armazenamento de dados e rede de transmissão de dados.

\subsubsection{Computador}

O computador é o elemento mais importante para a informatização do processo judicial. $\mathrm{Na}$ verdade, todas as etapas estão baseadas na utilização de sua plataforma. $\mathrm{O}$ computador é o "cérebro eletrônico" com grande capacidade de processamento de 
informações, por meio do qual os autos deixarão de ser físicos, ou materiais, para se tornarem digitais.

O website Museu do Computador (www.museudocomputador.com.br) relata parte da história da evolução do pensamento humano voltado para o descobrimento de técnicas, elementos e invenções, cuja criação e desenvolvimento foram imprescindíveis à invenção do computador bem como o desenvolvimento do mesmo na história. Para uma maior compreensão da evolução aqui mencionada, oportuno é trazer à colação a Tabela 1, que enumera os principais eventos descritos pelo website Museu do Computador:

\begin{tabular}{|c|c|}
\hline 4.000 A.C. & surgimento da escrita cuneiforme na mesopotâmia \\
\hline 1.300 A.C. & surgimento do alfabeto, substituto dos ideogramas, inventado provavelmente pelos Fenícios \\
\hline 550 A.C. & Pitágoras inventa o ábaco, sistema utilizado para cálculos matemáticos \\
\hline 735 D.C. & a imprensa surge no Japão \\
\hline 868 D.C. & impressão do primeiro livro na China \\
\hline 1.088 D.C. & invenção do relógio mecânico na China \\
\hline 1.614 D.C. & $\begin{array}{l}\text { o primeiro texto sobre o descobrimento do logaritmo é publicado por Scotsman John Napier, que inventou ainda o sistema } \\
\text { de rods. A partir de então, se tornou possível o cálculo de raízes quadradas e cúbicas, bem como de multiplicação e divisão } \\
\text { através da utilização dos inventos mencionados }\end{array}$ \\
\hline 1.623 D.C. & "relógio calculador" foi inventado por Wilhel Schickard \\
\hline 1.642 D.C. & invenção da máquina de somar pelo francês e matemático Blaise Pascal \\
\hline 1.672 D.C. & $\begin{array}{l}\text { invenção máquina de calcular capaz de desenvolver as quatro operações matemáticas básicas: soma, subtração, } \\
\text { multiplicação e divisão; pelo matemático Gottfried Wilhelm Von Leibnitz, por meio do aprimoramento da máquina de } \\
\text { calcular de pascal }\end{array}$ \\
\hline 1.672 D.C. & $\begin{array}{l}\text { invenção máquina de calcular capaz de desenvolver as quatro operações matemáticas básicas: soma, subtração, } \\
\text { multiplicação e divisão; pelo matemático Gottfried Wilhelm Von Leibnitz, por meio do aprimoramento da máquina de } \\
\text { calcular de pascal }\end{array}$ \\
\hline 1.801 D.C. & $\begin{array}{l}\text { surge o tear automático, que trabalhava mediante programação por meio de cartões perfurados. O tear é uma espécie de } \\
\text { hardware primitivo e os cartões perfurados, se assemelha ao software, que possibilita o trabalho do tear. O invento é } \\
\text { atribuído a Joseph Marie Jackuard e é considerado a primeira máquina programável da história }\end{array}$ \\
\hline 1.848 D.C. & a álgebra binária, que tornou possível a criação do computador, foi inventada pelo matemático George Boole; \\
\hline 1924 D.C. & Surgimento da IBM, por meio da união da Tabulating Machine Company e duas outras pequenas empresas \\
\hline 1.941 D.C. & o computador "Z3" é inventado pelos Alemães e utilizado para codificação de mensagens na Segunda Guerra Mundial \\
\hline
\end{tabular}




\begin{tabular}{|c|c|}
\hline 1.943 D.C. & os Ingleses inventam o computador "Colossus", com a mesma finalidade de seu antecessor "Z3" \\
\hline 1.944 D.C. & Howard Aiken inventa o primeiro computador eletromecânico (Mark I) \\
\hline 1.946.D.C. & primeiro computador eletrônico (ENIAC) é construído por J. H. Mauchly e P. E. Junior \\
\hline 1.949 D.C. & $\begin{array}{l}\text { invenção do primeiro computador comercial, chamado "UNIVAC". Jonh Bardeen, Walter Brattain e William Shockley } \\
\text { patenteiam o primeiro transistor da história }\end{array}$ \\
\hline 1.953 D.C. & $\begin{array}{l}\text { o primeiro computador digital da história (IBM 701) é comercializado e em três anos, dezenove destas máquinas foram } \\
\text { vendidas }\end{array}$ \\
\hline 1.955 D.C. & surge o "Tradic", primeiro computador transistorizado, com aproximadamente 800 transistores \\
\hline 1.956 D.C. & $\begin{array}{l}\text { iniciam-se os testes de hardwares de entrada de dados em computadores por meio de teclados no Massachussets Institute of } \\
\text { Tecnology }\end{array}$ \\
\hline 1.957 D.C. & $\begin{array}{l}\text { a linguagem de programação "Fortran" é inventada. A partir de então, o computador pode realizar tarefas repetitivas a partir } \\
\text { de um conjunto de instruções }\end{array}$ \\
\hline 1.958 D.C. & a Texas Instruments cria o primeiro circuito integrado de resistores e capacitores, precursor das placas, chips e microchips \\
\hline 1.960 D.C. & surge o "Dataphone", primeiro modem comercial \\
\hline 1.961 D.C. & O UNIMATE, primeiro robô industrial inicia suas atividades na General Motors \\
\hline 1.962 D.C. & $\begin{array}{l}\text { o primeiro jogo de computador da história é escrito e desenvolvido por estudantes do Massachusetts Institute of Tecnology. } \\
\text { Seu nome era "Space War" }\end{array}$ \\
\hline 1.963 D.C. & $\begin{array}{l}\text { o primeiro microcomputador é vendido pela Digital Equipament e Douglas Engelbart recebe a patente do primeiro mouse } \\
\text { para computador }\end{array}$ \\
\hline 1.964 D.C. & é criada a linguagem de programação "Basic", uma das mais populares e revolucionárias de todos os tempos \\
\hline 1.965 D.C. & primeiro microcomputador comercializado com sucesso é introduzido pela DEC, ao preço de U\$ $18.000,00$ \\
\hline 1.966 D.C. & $\begin{array}{l}\text { a Hewlett-Packard entra no ramo da informática e lança o HP-2115, que suportava uma grande variedade de linguagens de } \\
\text { programação. No mesmo ano, a IBM apresenta o primeiro disco de armazenamento em massa, que tinha capacidade de } 5 \\
\text { MB de armazenamento }\end{array}$ \\
\hline 1.967 D.C. & $\begin{array}{l}\text { o precursor da impressora é lançado com o nome "LOGO", uma espécie de tartaruga mecânica que traçava uma trilha de } \\
\text { caneta pelo papel. No mesmo ano, é lançado o primeiro floopy disk pela IBM }\end{array}$ \\
\hline 1.969 D.C. & $\begin{array}{l}\text { programadores dos laboratórios AT\&T desenvolvem o UNIX, o primeiro sistema operacional que poderia ser utilizado em } \\
\text { qualquer máquina e percussor de outros sistemas operacionais da atualidade, como o OSX da Apple e o Linux, sistema de } \\
\text { código aberto. Nesse mesmo ano, máquinas da Arpanet foram interligadas pelo exército americano, formando a rede que } \\
\text { viria a originar a Internet }\end{array}$ \\
\hline 1.970 D.C. & surgimento do primeiro robô móvel (SRI Shakey) e da primeira máquina de caixa automático \\
\hline 1.971 D.C. & surgimento do “Kenbak-1", computador pessoal vendido a U\$ 750,00. Criação do disco flexível de 8”, pela IBM \\
\hline $\begin{array}{l}1.976 \text { a } 1.979 \\
\text { D.C. }\end{array}$ & grande quantidade de microcomputadores são lançados no mercado \\
\hline 1.980 D.C. & invenção do primeiro HD, ou hard disk drive \\
\hline 1.981 D.C. & introdução do PC pela IBM no mercado, o maior sucesso de vendas no mercado de microcomputadores de todos os tempos. \\
\hline
\end{tabular}




\begin{tabular}{|c|c|}
\hline & $\begin{array}{l}\text { No mesmo ano, a Microsoft lança o sistema operacional MS-DOS, para o IBM PC. Ainda nesse ano, o primeiro } \\
\text { computador portátil, precursor do notebook é desenvolvido. Seu nome: Osborne }\end{array}$ \\
\hline $\begin{array}{l}1.982 \text { e } 1.983 \\
\text { D.C. }\end{array}$ & surgimento de vários softwares, dentre os quais o Microsoft Word \\
\hline 1.984 D.C. & a Apple Computer lança o Macintosh, o primeiro microcomputador com mouse e interface gráfica \\
\hline 1.985 D.C. & surgimento do CD Rom que veio revolucionar o mercado de armazenamento de áudio e dados \\
\hline 1.988 D.C. & $\begin{array}{l}\text { A Pixar de Steeve Jobs ganha o primeiro prêmio da Academia, o Oscar, pelo filme feito em computador da história, o "Tin } \\
\text { Toy" }\end{array}$ \\
\hline 1.990 D.C. & a primeira versão do Microsoft Windows é lançada no mercado \\
\hline 1.992 D.C. & o vírus de computador "Michelangelo" causa estragos a nível mundial, mas em pequena proporção \\
\hline 1.993 D.C. & lançado o primeiro PDA, espécie de Palm Top, pela Apple. No mesmo ano, é apresentado o primeiro Intel Pentium \\
\hline 1.994 D.C. & o primeiro browser Netscape para navegação na Internet surge e dissemina o uso desse meio de comunicação pelo mundo \\
\hline 1.998 D.C. & lançamento do Windows 98 \\
\hline 1.999 D.C. & lançamento do sistema operacional LINUX, sistema operacional de código aberto, baseado na plataforma UNIX \\
\hline 2.001 D.C. & lançamento do Windows XP \\
\hline
\end{tabular}

Tabela 1: evolução da informática através ao longo do tempo

Fonte: www.museudocomputador.com.br. Acesso em 25 jan. 2009.

Os componentes básicos de um computador são: a CPU ou UCP (Unidade Central de Processamento), onde se localizam o microprocessador, placas de áudio, vídeo, memórias e disco rígido; o monitor o teclado e o mouse. No Superior Tribunal de Justiça, também são utilizados leitores de código de barra para facilitar o cadastramento de fases de processos no sistema.

\subsubsection{Impressoras}

As impressoras são periféricos de saída de dados, ou seja, equipamentos que conectados ao computador, permitem a exteriorização dos dados processados, geralmente em linguagem escrita, gráficos e desenhos. 
Vários são os modelos de impressoras existentes. As mais comuns são: 1) impressora a "jato de tinta", que utiliza cabeçotes de impressão compostos de um ou mais cartuchos de tinta, sendo de custo relativamente baixo, mas pouco veloz; e 2) impressora a laser, que utiliza o laser para sensibilizar um cilindro a partir do qual se dará a impressão. Seu custo é mais elevado que as impressoras a "jato de tinta", porém são mais velozes.

A impressora a laser tem sido utilizada para impressões em larga escala, tendo em vista a velocidade de impressão e a quantidade de folhas que pode imprimir sem ser recarregada.

\subsubsection{Digitalizadores}

Os digitalizadores são também conhecidos como scanners e constituem-se em periféricos de entrada de dados, ou seja, equipamentos que uma vez conectados ao computador, possibilitam abastecimento do mesmo com dados que podem variar de documentos escritos a imagens e gráficos.

Santos (2005, p. 46) traz algumas informações relevantes sobre o scanner e seu funcionamento:

\footnotetext{
Os scanners possuem um sensor luminoso que "lê" os pontos que formam uma determinada imagem e transfere esses pontos (a imagem) para o computador. Existem vários modelos de scanners, a qualidade da imagem enviada para o computador é medida também em DPI (pontos por polegada). Podem digitalizar imagens coloridas ou em preto e branco.
}

Os digitalizadores ou scanners exercem função essencial na migração dos autos físicos para o meio eletrônico, uma vez que é através dessas máquinas que os documentos em forma de papel serão transformados em documentos digitais, por meio da sua conversão em bits de computador. 


\subsubsection{Servidores para armazenamento de dados}

Cada computador possui em sua CPU em disco rígido, HD ou hard disk, que é um dispositivo de armazenamento de dados, formado por "vários discos não flexíveis, de metal, revestidos com material magnético nas duas faces, alocados com os cabeçotes de leitura/gravação em um bloco fechado a vácuo" (SANTOS, 2005, p. 32). Tudo o que fica armazenado no computador, incluindo os softwares para operação do mesmo estão gravados, em regra, no disco rígido.

Servidores para armazenamento de dados, por seu turno, são como "discos rígidos" de grande capacidade de armazenamento. Esses servidores ficam geralmente em locais específicos e se comunicam com os demais computadores por meio de uma rede como a internet, por exemplo.

Os dados constantes do servidor, de modo geral, não podem ser apagados em definitivo por meio dos computadores de usuários a eles interligados. Esses, em regra, somente acessam os dados constantes dos servidores.

Os processos eletrônicos, por exemplo, ficariam armazenados em servidores, e que seriam então acessados por partes, advogados etc.

\subsubsection{Redes de transmissão de dados}

Santos (2005, p. 542) define rede como "uma ligação de vários computadores e/ou outros equipamentos (periféricos), interligados, que trocam informações e compartilham recursos, facilitando o trabalho do usuário. Seus objetivos, segundo o autor, consistem em permitir a comunicação por meio da transferência de informação entre os diversos 
computadores e demais equipamentos a ela conectados, aumentando o acesso às informações disponíveis e reduzindo o custo do processamento de dados.

As redes utilizam uma série de equipamentos materiais para a sua existência, que vão desde computadores e servidores de armazenamento de dados até cabos, conectores e transmissores sem fio.

De complexidade variável, as redes podem agrupar de dois a milhares de computadores em todo o mundo como é o caso da internet.

A rede que interliga um grupo de computadores em uma mesma localidade é chamada LAN (local área network) e utilizada em escritórios e corporações em uma mesma localidade. A intranet, ou rede local, é uma espécie de LAN. Atualmente, grande parte dos órgãos públicos (incluindo os Tribunais) e diversas corporações privadas possuem intranet. Essa é utilizada para a disseminação de informações e consultas dentro do respectivo órgão. No Superior Tribunal de Justiça, a intranet disponibiliza consultas processuais, acesso a notícias, consultas a informações pessoais de cada servidor por meio da utilização de senha de acesso, dentre outros.

A maior rede de intercomunicação existente no planeta é a chamada internet ou Rede Mundial de Computadores. A internet, nos termos da Lei n. 11.419/2006, será o elemento basilar na difusão, acesso e consulta de dados relativos ao processo eletrônico. Tanto é verdade, que em seu art. 14 prescreve a lei que os sistemas utilizados pelo Poder Judiciário deverão ser "acessíveis ininterruptamente por meio da rede mundial de computadores".

Diferentemente da intranet que geralmente é de uso restrito e direcionada às pessoas vinculadas aos respectivos órgãos onde elas existem, a internet é uma rede mundial aberta a todos os cidadãos do planeta. 
Para se conectar à internet é preciso um computador com placa de modem ou de rede, uma conexão por linha discada (por meio de telefone), banda larga (geralmente por meio de modem dsl, rádio, satélite ou cabo) e ainda, em determinados casos, acesso a um provedor responsável pela conexão do computador à internet. É necessário ainda um software conhecido genericamente como browser ou "navegador", que é o programa utilizado pelo computador para ser possível a "navegação" na rede mundial de computadores. Como exemplo de browsers podem ser elencados o Internet Explorer, da Microsoft; o Mozilla Firefox da Mozilla e o Safari da Apple.

O bem primordial da internet é a informação e sua utilização, quase inevitável por boa parcela da população mundial. Blum (2002, p. 145) sobre a utilização massiva da internet e suas conseqüências, destacou:

\begin{abstract}
A dependência do mundo virtual é inevitável. Grande parte das tarefas do nosso diaa-dia são transportadas para a rede mundial de computadores, ocasionando fatos e suas conseqüências jurídicas e econômicas, assim como ocorre no mundo físico. A questão que surge é relacionada aos efeitos dessa transposição de fatos, basicamente a sua interpretação jurídica. Como exemplo, podemos citar a aplicação das normas comerciais e de consumo nas transação via Internet (responsabilidade perante o Código do Consumidor), a questão do recebimento indesejado de mensagens via $e$ mail (spam), a validade jurídica do documento eletrônico, o conflito de marcas com os nomes de domínio, a propriedade intelectual e industrial, a privacidade, a responsabilidade dos provedores de acesso, de conteúdo e de terceiros na web e os crimes de informática.
\end{abstract}

Quanto à aplicação de leis para a regulamentação dos fatos descritos, continua o autor

(BLUM, 2002, p. 145):

A legislação brasileira pode e vem sendo aplicada na maioria dos problemas relacionados à rede. Para questões específicas e controvertidas, como aquelas citadas, existem projetos de lei em tramitação, os quais devem objetivar a complementação e adequação como princípios fundamentais, sob pena de uma inflação legislativa desnecessária. Acrescente-se que diversas nações possuem regulamentação sobre os temas, destacando-se os Estados Unidos, membros da União Européia, Canadá, Colômbia, Itália, Alemanha e Portugal. No Brasil, ainda que de forma embrionária, destacamos a recente Lei n. ${ }^{\circ}$ 9.800/1999 permite o envio de petições via e-mail ao Poder Judiciário, observados certos requisitos e a Lei n. ${ }^{\circ}$ 9.983/2000, que tipifica condutas criminosas quanto a prejuízos aos sistemas informatizados da Administração Pública. 


\subsection{Software}

Os softwares são os programas utilizados pelo hardware para que esse execute as suas funções. Santos (2005, p. 11), traz a seguinte definição para software:

São os procedimentos que controlam, desempenham atividades e mantêm o funcionamento do computador. Mais precisamente, o software é a parte lógica do computador que controla todo o processo de transformação dos dados em informações. Pode-se dizer que é toda parte de programação de um computador. Assim como o computador armazena dados, ele também pode armazenar uma longa série de instruções. Essa série, por sua vez, forma um programa de computador.

Os softwares são responsáveis pela operacionalização do computador. São eles que contêm as instruções e os parâmetros necessários para que o computador realize as tarefas que lhes são destinadas.

Segundo o art. 14 da lei da informatização do processo judicial "os sistemas a serem desenvolvidos pelos Órgãos do Poder Judiciário deverão usar, preferencialmente programas com código aberto (...)".

A terminologia "sistema de código aberto", ou open source em inglês, foi criado pela OSI - Open Source Initiative e é sinônimo de software livre.

O site governamental software livre <www.softwarelivre.gov.br> traz a definição de software livre:

(...) segundo a definição criada pela Free Software Foundation é qualquer programa de computador que pode ser usado, copiado, estudado, modificado e redistribuído com algumas restrições. A liberdade de tais diretrizes é central ao conceito, o qual se opõe ao conceito de software proprietário, mas não ao software que é vendido almejando lucro (software comercial). A maneira usual de distribuição de software livre é anexar a este uma licença de software livre, e tornar o código fonte do programa disponível. 
Em resumo, a viabilidade econômica da utilização do software livre ou sistemas de códigos abertos é muito maior do que a utilização dos softwares de códigos fechados, como os programas e sistemas operacionais da Microsoft, por exemplo; uma vez que enquanto estes exigem o pagamento pela sua utilização, aqueles são gratuitos.

\subsection{Insumos que dependem da utilização de hardwares e softwares para se efetivarem e a sua implementação no STJ}

Existem alguns elementos materiais e virtuais contidos na lei, estritamente necessários à implementação do processo judicial. São eles: assinatura digital, petição eletrônica, e diário de justiça eletrônico.

O presente tópico analisará cada um desses elementos e a seu estágio de implementação no Superior Tribunal de Justiça.

\subsubsection{Assinatura Digital}

Um dos maiores desafios da informática na atualidade está relacionado à segurança na transmissão de dados e na identificação dos agentes envolvidos na transação: emissor e receptor das informações transmitidas.

Enquanto no documento físico, em sua maioria na forma de papel, existe a possibilidade de se confrontar a assinatura fornecida com a que consta no documento de identidade do emitente e até mesmo em casos extremos, realizar perícias na letra para identificar seu autor; no documento digital tais procedimentos, da forma que foram aqui apresentados, não são suscetíveis de serem utilizados. 
No documento digital, a fonte geralmente é padrão (times new roman, arial etc) e não há uma assinatura como a feita em papel, com "tinta e caneta" e por meio da caligrafia. Desta forma, como garantir a segurança das informações transmitidas?

Kaminski e Volpi (2004, p. 248), no tocante à segurança, sobre a diferença entre os documentos físicos e digitais, destacam:

\begin{abstract}
O divisor de águas principal entre a segurança oferecida por um documento comum e a segurança ofertada por um documento eletrônico está, justamente, no meio de suporte. Em se tratando de um documento comum, escrito sobre o papel, repousam letras grafadas, descrevendo determinada situação, adicionadas ainda de uma manifestação de vontade, que é geralmente representada por uma assinatura de próprio punho.

Já no documento eletrônico, continua existindo a descrição da situação, entretanto suportada por diferentes meios de mídia digital, que podem ser considerados indecifráveis para o ser humano, senão através de um programa de computador. O maior agravante reside justamente no fato de que, por meio de um programa de computador, pode-se alterar o conteúdo do documento eletrônico, se que reste qualquer vestígio. Já no documento suportado pelo papel, qualquer alteração tornase de difícil feitura, uma vez que se encontra em um meio impresso.
\end{abstract}

Segundo Kaminski e Volpi (2004, p. 248), a segurança no meio digital, em sentido amplo, envolve duas premissas: a possibilidade de identificação do autor ou transmitente do documento e do receptor; e a certeza de que o documento não sofreu nenhuma alteração no curso da transmissão, ou seja, que a "integridade" do documento foi mantida.

Em se tratando de informações transmitidas pela rede mundial de computadores, a internet, o IP - Internet Protocol, é a forma primária de localização dos emitentes e destinatários das informações transmitidas na rede. Segundo Gois Júnior (2002, p. 57), os IP’s são "códigos atribuídos a cada ponto de conexão da internet e em geral tem a forma de um grande número de nove dígitos como 216.32.74.52, o IP da yahoo.com”.

Os IP's, no entanto, possuem grande limitação no que se refere à questão de segurança das informações transmitidas, já que fornece tão somente o "endereço" dos computadores envolvidos na transmissão e recepção das informações. Ocorre que um computador pode ter 
diversos usuários diferentes e por isso o "IP" não é capaz, em regra, de identificar o usuário que transmitiu a informação, mas somente o computador do qual partiu a mesma.

A certificação digital é o meio, na atualidade, mais eficiente no que tange à garantia de identificação de emissor e receptor das informações na rede, bem como da integridade dos dados transmitidos. Os certificados digitais fazem uso de uma assinatura digital, por meio da qual se garante a autenticidade do documento eletrônico, que contém a assinatura digital do emissor. O conceito de assinatura digital é fornecido por Kaminski e Volpi (2004, fl. 250):

\begin{abstract}
A assinatura digital é uma técnica que se utiliza do conteúdo a ser assinado, somando-se a chave privada do emissor, para a criação de um conjunto de caracteres que irá acompanhar o conteúdo. O receptor desse conteúdo, para que se tenha ciência da integridade do mesmo, utiliza-se da combinação do próprio conteúdo, da chave pública do emissor e da assinatura digital. Assim, pode constatar a existência de qualquer alteração. Caso tenha havido mudança de um caractere sequer, a combinação acusa que o conteúdo não confere com o originalmente emitido.
\end{abstract}

Os autores asseveram, outrossim, que a assinatura digital não deve ser confundida com "assinatura digitalizada". Enquanto essa é apenas a assinatura física do autor do documento, capturada por meio de um scanner, por exemplo; aquela se baseia exclusivamente em dígitos capazes de individualizar o autor e o emitente da informação transmitida, preservando sua integridade. Volpi (2002, p. 372) demonstra, na prática, como se dá a certificação digital:

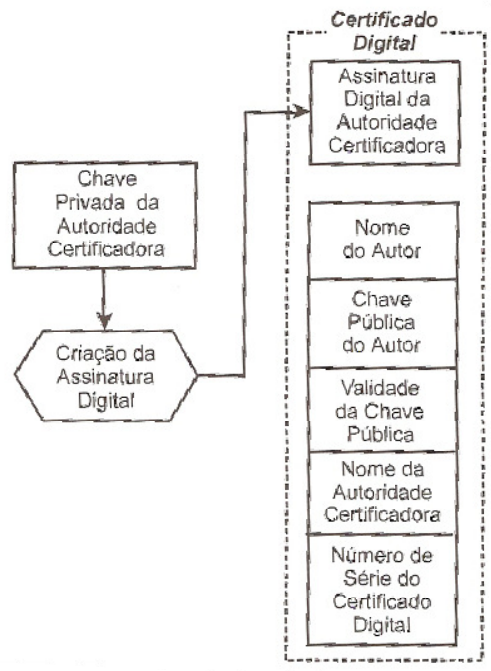

Figura 4: Organograma do procedimento de certificação digital.

Fonte: VOLPI (2002, p. 272) 
O passo mais importante para a implementação da assinatura digital no Brasil foi a edição da Medida Provisória n. ${ }^{\circ}$ 2.200-2 de 24 de agosto de 2001. Por meio dela foi instituída a "Infra-Estrutura de Chaves Públicas Brasileira / ICP-Brasil", o que possibilitou a plena validade do documento eletrônico em todo território nacional.

As medidas provisórias têm eficácia limitada em razão do tempo (LENZA, 2005, p. 259), ou seja, prazo de validade determinado, perdendo sua eficácia se não forem convertidas em lei.

No caso da Medida Provisória n. ${ }^{\circ}$ 2.200-2/2001, mesmo sem ter sido convertida em lei ela, excepcionalmente, não perdeu sua validade e eficácia, em razão do que dispôs a Emenda Constitucional n. ${ }^{\circ}$ 32/2001, segundo a qual as medidas provisórias publicadas até 11 de setembro de 2001, continuariam em vigor até que "medida provisória ulterior as revogue explicitamente ou até deliberação definitiva do Congresso Nacional" (art. $2^{\circ}$ ), o que até o início de 2009 não ocorreu.

O Comitê Gestor da Infra-Estrutura de Chaves Públicas Brasileira - CG ICP-Brasil, sua Secretaria-Executiva, sua Comissão Técnica Executiva foram, a princípio, regulamentados pelo Decreto n. ${ }^{\circ} 3.872$ de 18 de julho de 2001 .

Em 14 de outubro de 2008, foi o mesmo revogado pelo Decreto ${ }^{\circ}{ }^{\circ} 6.605$, que passou então a regulamentar Comitê Gestor da Infra-Estrutura de Chaves Públicas Brasileira - CG ICP-Brasil, sua Secretaria-Executiva e sua Comissão Técnica Executiva, chamada de COTEC.

A assinatura digital para servidores lotados em diversos órgãos do Superior Tribunal de Justiça já foi disponibilizada e em 10 de dezembro de 2008, a Secretaria dos Órgãos Julgadores do Superior Tribunal de Justiça, responsável por gerir os trabalhos das 
Coordenadorias da Corte Especial, das três Seções, das seis Turmas, Execução Judicial e

Secretaria de Recursos Extraordinários, encaminhou e-mail a seus subordinados, no qual mencionava as regras para a aquisição da assinatura digital por parte dos servidores.

O procedimento, na oportunidade, para a aquisição da assinatura digital é dividido em três fases, conforme se segue:

\section{Primeira fase - Solicitação do Certificado:}

- Preencher o formulário de informações no sitio http://icp.caixa.gov.br/, opção "solicitação". Na página seguinte escolher o perfil "Cert-JUS - Institucional". Os campos "Número do PIS/PASEP" e "Número do CEI" são opcionais, mas, se preenchidos, original e cópia devem ser apresentados à CEF;

- Muito importante. O campo "Login de rede" deve ser preenchido com o Nickname seguido de @stj.gov.br, que vem a ser o domínio do STJ. Exemplo: silva@stj.gov.br. A CEF não permite a finalização da solicitação sem o campo corretamente informado. $\mathrm{O}$ preenchimento incorreto deste campo inviabiliza o serviço de login de rede;

\section{Segunda Fase - Identificação pessoal:}

- Agendar horário na CEF para entrega dos documentos. A agência que nos atende é a do STJ (0847 - STJ). A apresentação deve ser agendada com o gerente Eliardo Ou Elizabeth, através do ramal 8245, 8246 e 8247. Os horários sugeridos são, antes da abertura da agência (11h30) e após o fechamento (16h30);

- Originais e cópias dos documentos devem ser apresentados à CEF, pessoalmente. O prazo para entrega é de dez dias após o preenchimento da página de Solicitação. Se o prazo expirar, o formulário de solicitação deve ser novamente preenchido;

- Assinatura do termo de Compromisso na agência;

- O usuário deve receber duas "chaves", que serão utilizadas na próxima fase, para baixa do Certificado. A liberação para utilização se dará em 48 horas, no mínimo;

\section{Terceira Fase - Emissão do Certificado:}

- O registro ou baixa (enroll) do Certificado pode ser executado na SESRE (Seção de Segurança de Rede - STI);

- O cartão (SmartCard) pode ser retirado pessoalmente ou por representante na SESRE (Horácio), sala F120, ramal 9530.

- Os cartões necessitam de uma formatação inicial, a ser executada na SESRE, quando será solicitada uma senha PUK

(Personal Unblocking KEY), usada para reativar um SmartCard bloqueado e uma PIN (Personal Identification Number - Número de Identificação pessoal). Por razões de segurança, recomendamos senhas com 8 dígitos;

Lista de documentos para apresentação à CEF:

\section{CAIXA-Justiça}

- Foto $3 \times 4$ recente;

- Carteira de Identidade ou Passaporte, em caso de estrangeiro;

- CPF;

- Título de Eleitor;

- Documento de Identificação Funcional ou Declaração do departamento de -

Recursos Humanos ou equivalente, do órgão de lotação;

- Comprovante de residência;

- PIS/PASEP (opcional se não informado, obrigatório de informado); 
- CEI - Cadastro Específico do INSS (opcional se não informado, obrigatório de informado).

A CEF exige a apresentação da autorização do STJ para emissão do Certificado. Esse documento, encontra-se na CEF, em poder do Gerente.

\subsubsection{Petição Eletrônica}

Caldas Aulete, em seu dicionário da língua portuguesa, define petição, em termos genéricos, como "ação ou resultado de pedir" e "pedido escrito dirigido a uma autoridade ou a um tribunal".

De fato, a petição no processo judicial é um documento que em regra tem a natureza de requerimento, mas pode ser, outrossim, informativo etc. Se apresenta na forma escrita ou oral (posteriormente reduzida a termo), com a finalidade de provocar a Jurisdição Estatal (petição inicial), ou praticar os demais atos concernentes ao processo e relativos à instrução processual.

A partir da petição inicial surge processo judicial. Esta é o documento formal endereçado ao Poder Judiciário, para que esse tome ciência de determinada situação ocorrida ou na eminência de ocorrer e dê a resposta ao caso, por meio do exercício da tutela jurisdicional, após o término da instrução processual.

Segundo Theodoro Júnior (2001, p. 318), “sem a petição inicial, não se estabelece a relação processual. É ela que tem a força de instaurar o processo e de fixar o objeto integral daquilo que vai ser solucionado pelo Órgão Jurisdicional: o litígio”.

As demais petições podem ser desde respostas ao pedido inicial (contestação - art. 300 a 303 do CPC, recovenção - art. 315 a 318 do CPC etc), como solicitações diversas (pedidos incidentais no curso do processo, como a argüição de falsidade - arts. 390 a 395 do CPC), além de recursos contra decisões proferidas (por exemplo, a apelação - arts. 513 a 521 do CPC), dentre outras. 
Para que a petição tenha validade, ela deve seguir uma série de requisitos constantes da legislação processual, especificamente os do art. 282 e 283 do Código de Processo Civil, além de outros. Deve ainda ser assinada e o autor da assinatura deve possuir, para o caso que se apresenta, capacidade postulatória para atuar em juízo (Título II, do Código de Processo Civil).

A petição "física", ou seja, originalmente escrita ou reduzida a termo sendo oral, deve ser entregue diretamente no respectivo órgão judiciário, onde é protocolada, meio pelo qual recebe um número identificador, além de ter certificada a data e o horário de sua entrega no órgão, com a finalidade de ter sua tempestividade posteriormente auferida pela Autoridade Judiciária.

A regra é que a parte ou o seu representante compareça pessoalmente ao órgão judiciário e protocole a petição, mas, tendo em vista a enorme extensão territorial do país e a grande dificuldade de locomoção para o protocolo de uma simples petição, os Juízos e Tribunais atualmente admitem a remessa da petição e dos documentos que a instruem por meio do sistema de correios.

No ano de 1999 foi promulgada a Lei n. ${ }^{\circ}$ 9.800, conhecida como "Lei do Fax". Tal lei possibilitou a remessa de petição aos órgãos judiciais via fax ou outro similar, para todos os atos que dependessem de petição escrita $\left(\operatorname{art.} 1^{\circ}\right)$.

Apesar dessa facilidade, a lei determinava que os originais deveriam ser entregues no órgão para onde a transmissão havia sido feita no prazo de cinco dias da data da recepção do material (art. $2^{\circ}$, parágrafo único).

Para alguns casos, o advento da lei trouxe grandes benefícios. Se uma petição de recurso devesse ser protocolada no prazo de cinco dias, a partir da publicação de uma decisão, 
poder-se-ia enviar a petição via fax dentro do prazo previsto. A partir da data do envio do fax, contar-se-iam mais cinco dias para o encaminhamento dos originais.

Não se pode afirmar, no entanto, que as petições encaminhadas via fax são legitimamente petições eletrônicas. Primeiramente, pois digital é apenas o meio de transmissão e não a petição em si, que continua se constituindo na forma de papel; e depois pelo fato da lei exigir o envio do original dentro do prazo de cinco dias.

A Lei n. ${ }^{\circ}$ 11.419/2006, por seu turno, inovou ao criar, em definitivo a petição eletrônica. Os comentários sobre os artigos da lei que tratam do tema já foram realizados no tópico 5.3.2 do presente trabalho.

A petição eletrônica poderá ser utilizada tanto no processo físico quanto no processo digital. Em se tratando do processo físico, a petição será encaminhada eletronicamente e impressa no órgão judiciário para ser juntada aos autos, o que já ocorre atualmente no Superior Tribunal de Justiça. Não será, no entanto, necessária a remessa de qualquer documento posteriormente. A petição eletrônica se constitui no próprio original. Já no caso do processo eletrônico, não haverá necessidade de impressão da mesma, sendo esta juntada aos autos pela própria parte que a expedir.

No Superior Tribunal de Justiça, a petição eletrônica foi regulamentada pela Resolução n. ${ }^{\circ} 2$ de 24 de abril de 2007, emanada pelo Exmo. Sr. Ministro Raphael de Barros Monteiro, então Presidente da Corte.

Segundo esta resolução, o peticionamento eletrônico estaria restrito aos processos de competência originária do Presidente do Tribunal, nos habeas corpus e nos recursos ordinários em habeas corpus. Em 05 de novembro de 2007, o mencionado artigo foi alterado pela Resolução n. ${ }^{\circ} 9$ do Presidente da Corte, que ampliou o uso do petição eletrônica para todos os processos do Tribunal e não somente para as três modalidades inicialmente previstas. 
O serviço é facultativo e está disponível no website do Superior Tribunal de Justiça (www.stj.jus.br). No entanto, quem utilizar o serviço deverá se submeter às regras relacionadas à formatação e ao tamanho do documento, cujos parâmetros estão disponíveis no mesmo site.

Nos termos da Lei n. ${ }^{\circ} 11.419 / 2006$, se houver documentos a instruírem a petição eletrônica, cuja digitalização seja inviável tecnicamente em razão do tamanho, ou em razão daquela tornar os documentos ilegíveis, estes deverão ser remetidos ao cartório ou à secretaria do Tribunal no prazo de dez dias contados do envio da petição eletrônica.

É dispensado o envio dos originais posteriormente em razão da assinatura digital e o usuário do serviço deverá adquirir sua identidade digital junto à Infra-Estrutura de Chaves Públicas Brasileira - ICP - Brasil. O protocolo é emitido pelo próprio usuário mediante consulta ao sistema.

A consulta sobre as petições transmitidas e o acesso aos seus recibos poderão ser feitas em qualquer tempo pelo usuário. A responsabilidade pela manutenção do sistema é do Tribunal, embora os dados constantes da petição transmitida sejam de inteira responsabilidade do signatário das mesmas.

Por fim, caberá ao usuário atentar para as diferenças de fuso horário, sendo que para fins de contagem de prazo, adotar-se-á o horário oficial de Brasília, obtido junto ao Observatório Nacional.

\subsubsection{Diário de Justiça Eletrônico ou on line}

Tradicionalmente, os atos do poder público, em ambas as esferas de governo, eram publicados na Imprensa Oficial Federal ou local. Os atos do Poder Judiciário, se de natureza 
administrativa, eram publicados em regra nos chamados "Diários Oficiais" e se jurisdicionais, nos "Diários da Justiça".

Os atos referentes aos órgãos que compõem o Poder Judiciário na esfera federal: Supremo Tribunal Federal, Tribunais Superiores, Justiça Federal, Justiças Especializadas, além do Tribunal de Justiça do Distrito Federal e Territórios são publicados na Imprensa Oficial Federal, cujo representante é a Imprensa Nacional.

A criação de um Diário de Justiça Eletrônico gera a possibilidade de o órgão judiciário publicar diretamente seus atos por meio da internet, ficando dispensada a utilização da Imprensa Nacional. No Superior Tribunal de Justiça, a criação do Diário de Justiça Eletrônico foi regulamentada pela Resolução n. ${ }^{\circ} 8$ de 20 de setembro de 2007, do Exmo. Sr. Ministro Raphael de Barros Monteiro, então Presidente do Superior Tribunal de Justiça.

Dentre as principais inovações no que concerne à instituição do Diário de Justiça Eletrônico no Superior Tribunal de Justiça, pode-se citar a possibilidade de publicação tanto de atos judiciais, como administrativos e de comunicação em geral por esse meio. Ocorrerá ainda a substituição integral da versão impressa das publicações, anteriormente feita pela Imprensa Nacional, o que representará enorme economia de insumos materiais, como tinta, papel, entre outros, e redução significativa do impacto ambiental em razão desse fato.

Todas as edições serão assinadas digitalmente, seguindo as regras da Infra-Estrutura de Chaves Públicas Brasileira - ICP/Brasil, o que proporciona maior segurança às publicações realizadas. A publicação diária (segunda a sexta-feira), será mantida, agora a partir das 10:00h, exceto nos feriados forenses e quando não houver expediente. Não haverá, também, qualquer tipo de ônus às partes que solicitarem publicações no DJE. Por fim, a lei previu a transferência da responsabilidade pelas publicações do Tribunal da Imprensa Nacional (órgão externo) à Secretaria dos Órgãos Julgadores (órgãos internos do Tribunal). 


\section{OS BENEFÍCIOS DECORRENTES DA INFORMATIZAÇÃO DOS PROCESSOS JUDICIAIS NO SUPERIOR TRIBUNAL DE JUSTIÇA}

Por tudo o que foi relatado, não seria equivocada a afirmação de que o processo virtual, em sua integralidade, exigirá muito do Superior Tribunal de Justiça, de seus Servidores e Ministros, bem como da sociedade como um todo.

Os insumos materiais necessários à implementação plena do processo virtual demanda soma vultuosa de investimento, tanto em materiais quanto em capacitação humana. Da mesma forma, paradigmas terão que ser quebrados, pois o que a lei propõe é a extinção do processo físico, que existe desde os primórdios da jurisdição estatal, para dar lugar ao processo digital.

Essa hercúlea transição somente será válida, se os benefícios oriundos da implementação do processo virtual compensar e superar tamanha demanda. Portanto, serão analisados os benefícios advindos de tal mudança e a sua repercussão no Superior Tribunal de Justiça.

A missão precípua do Tribunal, conforme mencionado, está intimamente ligada aos três aspectos do processo judicial e seu trâmite: acessibilidade, celeridade e efetividade.

De fato, o que a sociedade espera do Poder Judiciário é que esse permita a provocação de qualquer do povo (acessibilidade), e que a sua resposta ao litígio proposto seja ágil (célere) e justa (efetiva), sempre norteada pelos princípios morais, éticos e legais. Desta forma, os benefícios oriundos da informatização do processo judicial deverão, necessariamente, gravitar sobre estes três aspectos e é levando-os em consideração que a presente análise será feita. 


\subsection{Acessibilidade Processual}

$\mathrm{O}$ art. $5^{\circ}$, inciso XXXV da Constituição Federal estatui que "a lei não excluirá da apreciação do Poder Judiciário nenhuma lesão ou ameaça de direito".

O artigo consagra o Princípio da Inafastabilidade da Jurisdição, por meio do qual qualquer violação a direito legalmente previsto deve ser apreciada pelo Poder Judiciário. Em alguns casos, como nas lesões patrimoniais (as descritas pelo Código Civil, por exemplo), é facultado à parte que se achar lesada, o direito de provocar o Judiciário; em outros, como nos crimes de ação penal pública incondicionada (art. 24 do Código de Processo Penal), caberá ao Ministério Público, desde que entenda que tenha havido o crime, ofertar obrigatoriamente a peça acusatória. Em qualquer uma das hipóteses, o Poder Judiciário deverá se manifestar.

O respaldo constitucional por meio do Princípio da Inafastabilidade da Jurisdição soluciona em definitivo o problema do acesso do cidadão ao Judiciário no Brasil?

Reconhecidamente não. O fato de o Brasil ser um país em desenvolvimento, enfrentar graves problemas relacionados à desigualdade social e a educação é um grande entrave ao acesso do cidadão comum à Justiça.

A possibilidade de fatores sócio-econômicos impedir o acesso do cidadão ao Judiciário é reconhecida pela própria Carta Magna de 1998, e institui no art. 134 a Defensoria Pública, elevando-a ao patamar de "instituição essencial à função jurisdicional do Estado, incumbindo-lhe a orientação jurídica e a defesa em todos os graus dos necessitados (...)".

Outro aspecto relevante no que se refere ao acesso do cidadão ao Judiciário é a extensão do Território Brasileiro. O ponto é relevante na medida em que o nosso sistema judiciário adota o "Princípio do Duplo Grau de Jurisdição", ou seja, confere ao cidadão o direito - desde que preenchidos alguns requisitos constantes da legislação processual - de ter a 
decisão judicial proferida no processo em que é parte reexaminada por órgão jurisdicional hierarquicamente superior.

Em termos práticos, isso quer dizer que alguém condenado por um Juiz de Direito (primeiro grau de jurisdição), tem o direito de recorrer para um Tribunal (segundo grau de jurisdição), que reexaminará a decisão anteriormente proferida, ratificando-a, ou alterando-a.

Além dos tradicionais primeiro (Juízes e Varas) e segundo grau de jurisdição (Tribunais de Justiça e Tribunais Regionais Federais), existem as instâncias especiais (Tribunais Superiores) e extraordinária (Supremo Tribunal Federal), que podem reexaminar questões decididas, na sua maioria, em segundo grau de jurisdição.

O problema surge na medida em que nem sempre os órgãos jurisdicionais mencionados ficam no mesmo lugar ou região, na verdade, quase nunca. Somente Brasília tem Varas Judiciais (primeiro grau), Tribunais de Justiça e Regional Federal (segundo grau), Tribunais Superiores (instância especial) e o Supremo Tribunal Federal (instância extraordinária) na mesma cidade.

Desta forma, se um cidadão em Brasília entrar com determinada ação judicial, e esta subir em forma de recurso para o Tribunal de Justiça, depois para o Superior Tribunal de Justiça e por fim ao Supremo Tribunal Federal, as partes e seus advogados não terão muitas dificuldades para acompanhar todo o curso processual, já que todos os órgãos jurisdicionais ficam em Brasília.

No caso de um cidadão que more em uma cidade do interior do Rio Grande do Sul e entre com uma demanda na justiça comum estadual, por exemplo. Haverá grande dificuldade, principalmente sobre o ponto de vista financeiro para que esse acompanhe todo o curso da ação intentada. Isso pois, em caso de recurso da sentença proferida em primeiro grau, o processo será encaminhado ao Tribunal de Justiça do Estado do Rio Grande do Sul, que fica 
em Porto Alegre (capital). Em caso de novo recurso o processo será remetido para o Superior Tribunal de Justiça em Brasília podendo ser ainda encaminhado ao Supremo Tribunal Federal, também localizado nessa mesma cidade.

No entanto, os processos físicos, salvo se houver cópia dos mesmos em outro local, estão sempre em um único lugar. Isto que dizer que se o processo está sendo analisado pelo Superior Tribunal de Justiça, as petições, documentos e provas deverão ser encaminhados ao Tribunal. Isto pode facilmente ser feito via correios. O problema é que para responder ou se defender de uma alegação feita pela parte adversa no Superior Tribunal de Justiça, como regra, o cidadão do interior do Rio Grande do Sul (no exemplo citado) deverá ter que ir pessoalmente até o Tribunal ou enviar um advogado para poder ter acesso ao que está sendo alegado pela parte adversa. Isso por ilimitadas vezes até o deslinde final da controvérsia.

Em alguns casos é imprescindível a presença do advogado na Seção de Julgamento para fazer a defesa de seu cliente oralmente e, os gastos são consideráveis se forem levados em conta a distância a ser percorrida (muitas vezes de avião), a hospedagem, transporte, alimentação etc.

O "Relatório Estatístico - Ano 2008”, elaborado pela Coordenadoria de Estatística do Superior Tribunal de Justiça, disponibilizado no website do STJ <www.stj.jus.br>, traz a origem geográfica dos processos distribuídos no STJ no ano de 2008, conforme se depreende da figura 5: 


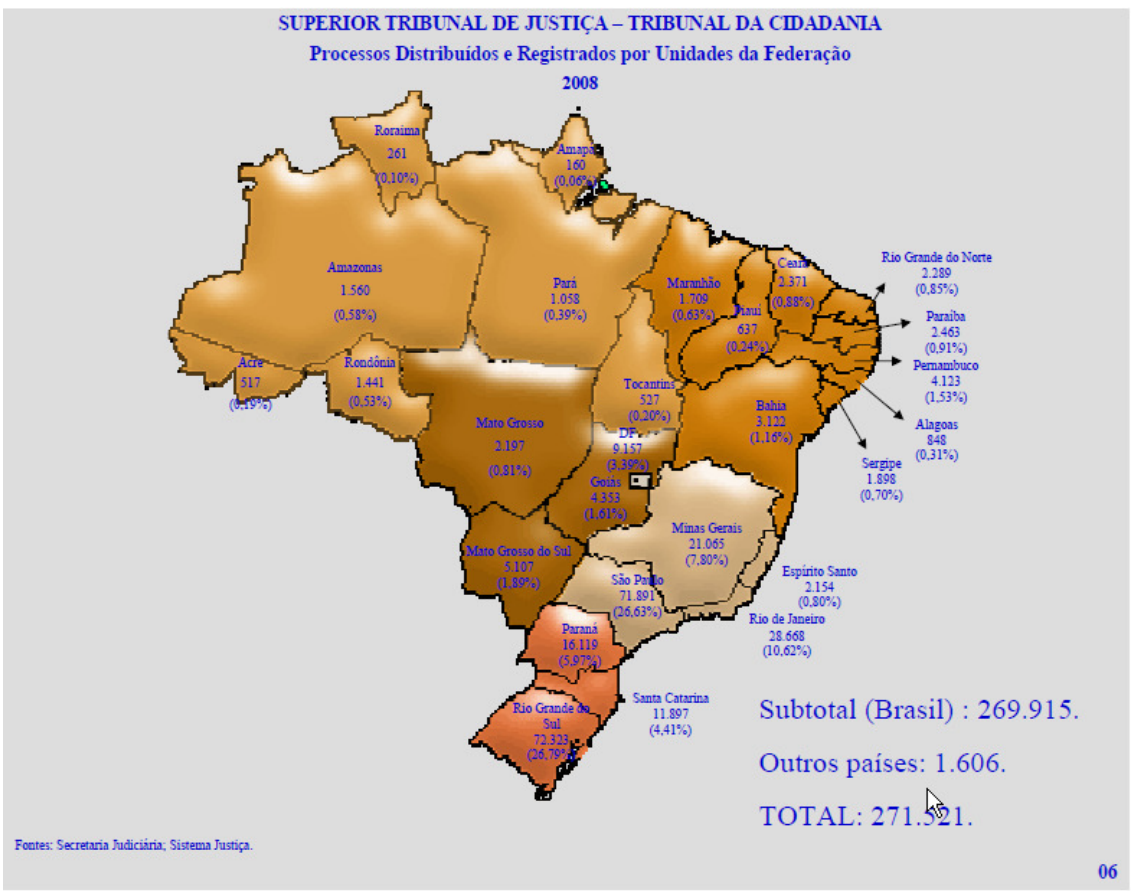

Figura 5: Processos distribuídos e registrados por Unidade da Federação - 2008. Fonte: Superior Tribunal de Justiça. Disponível em: <www.stj.jus.br>. Acesso em 25 jan. 2009.

A tabela 2 traz os dados mencionados individualizados numericamente:

1 - Processos Distribuídos e Registrados por Unidades da Federação - 2008

\begin{tabular}{|c|c|c|}
\hline \multirow{2}{*}{$\begin{array}{l}\text { Mês } \\
\text { Unidades da Federação }\end{array}$} & \multicolumn{2}{|c|}{2008} \\
\hline & Quantidade & $(\%)$ \\
\hline & 517 & 0,19 \\
\hline Alagoas & 848 & 0,31 \\
\hline Amapá & 160 & 0,06 \\
\hline Amazonas & 1.560 & 0,58 \\
\hline Bahia & 3.122 & 1,16 \\
\hline Ceará & 2.371 & 0,88 \\
\hline Distrito Federal & 9.157 & 3,39 \\
\hline Espírito Santo & 2.154 & 0,80 \\
\hline Golás & 4.353 & 1,61 \\
\hline Maranhão & 1.709 & 0.63 \\
\hline Mato Grosso & 2.197 & 0.81 \\
\hline Mato Grosso do Sul & 5.107 & 1,89 \\
\hline Minas Gerais & 21.065 & 7,80 \\
\hline Paráa & 1.058 & 0,39 \\
\hline Paraiba & 2.463 & 0.91 \\
\hline Paraná & 16.119 & 5,97 \\
\hline Pernambuco & 4.123 & 1,53 \\
\hline Piauí & 637 & 0,24 \\
\hline Rio de Janeiro & 28.668 & 10,62 \\
\hline Rio Grande do Norte & 2.289 & 0,85 \\
\hline Rio Grande do Sul & 72.323 & 26,79 \\
\hline Rondônia & 1.441 & 0,53 \\
\hline Roraima & 261 & 0,10 \\
\hline Santa Catarına & 11.899 & 4,41 \\
\hline Săo Paulo & 71.891 & 26,63 \\
\hline Sergipe & 1.898 & 0,70 \\
\hline Tocantins & 527 & 0,20 \\
\hline Subtotal & 269.915 & 100 \\
\hline Outros Países & 1.606 & \\
\hline Total & $271.521 \mid$ & \\
\hline
\end{tabular}

Tabela 2: Processos distribuídos e registrados por Unidade da Federação. Fonte: Superior Tribunal de Justiça. Disponível em: <www.stj.jus.br>. Acesso em 25 jan. 2009. 
Os números demonstram que do total de processos distribuídos e registrados no STJ no ano de 2008, apenas 3,39\% são oriundos do Distrito Federal, o que corresponde a 9.157 processos. Os demais 96,61\%, ou seja, 262.364 processos são advindos das demais regiões do país.

Somente o Rio Grande do Sul, um dos estados mais distantes do Distrito Federal, foi responsável por $26,79 \%$ dos processos distribuídos e registrados no STJ em 2008. Isso corresponde a nada menos do que 72.323 processos.

Para se ter uma idéia do impacto financeiro causado pelas mencionadas questões de natureza geográfica no Brasil, a tabela 3, o qual demonstra as distâncias consideráveis entre as principais capitais brasileiras e o Brasília, sede dos Tribunais Superiores e do Supremo Tribunal Federal:

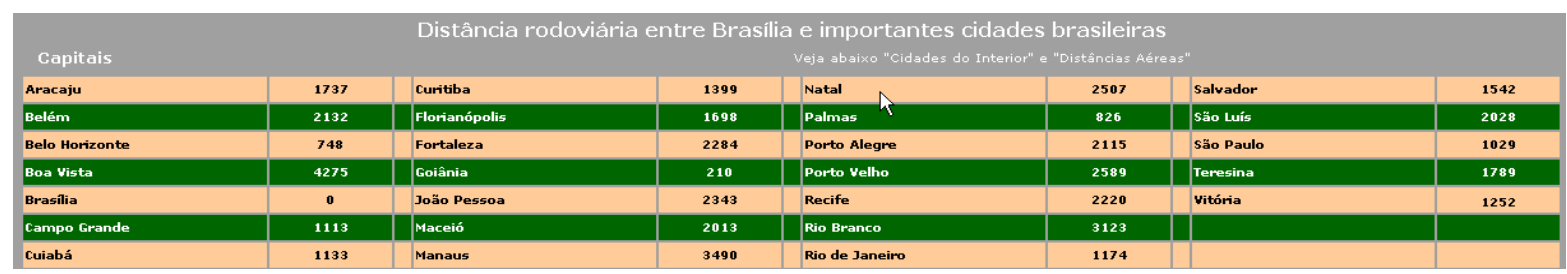

Tabela 3: distância rodoviária entre Brasília e importantes cidades brasileiras.

Fonte: http://www.emsampa.com.br/xspxdf.htm. Acesso em 25 jan. 2009.

Esse fato poderia ser irrelevante, se o Brasil fosse um país desenvolvido e de com uma distribuição satisfatória de renda, o que não é o caso.

Um artigo intitulado "Salário Mínimo e Distribuição de Renda", disponível no website do DIEESE <www.dieese.org.br>, demonstra a realidade da distribuição de renda no Brasil, em comparação com países desenvolvidos e em desenvolvimento. 
O mencionado artigo destaca que existe uma incrível desigualdade de distribuição de renda no país, ressaltando que, apesar do produto interno bruto do país estar aumentando e com isso o país estar ficando mais "rico", continua sendo ele um país de "muitos pobres", apesar de não ser considerado por muitos como país pobre.

Isto demonstra que de nada adianta o aumento do PIB do país se as reservas financeiras dele oriundas se concentram nas mãos de uma quase insignificante parcela da sociedade em termos numéricos.

A tabela 4 demonstra o que ora se afirma:

\begin{tabular}{|c|c|c|c|c|c|}
\hline País & $\begin{array}{c}\text { Data da } \\
\text { pesquisa }\end{array}$ & Índice de Gini & $\begin{array}{c}10 \% \text { mais } \\
\text { pobres }\end{array}$ & $\begin{array}{c}40 \% \text { mais } \\
\text { pobres }\end{array}$ & $\begin{array}{c}10 \% \text { mais } \\
\text { ricos }\end{array}$ \\
\hline África do Sul & 1995 & 0,593 & 0,7 & 6,3 & 46,9 \\
\hline Brasil & 1998 & 0,591 & 0,5 & 7,7 & 46,7 \\
\hline Chile & 2000 & 0,571 & 1,2 & 9,9 & 47,0 \\
\hline México & 2000 & 0,546 & 1,0 & 10,3 & 43,1 \\
\hline Argentina & 2001 & 0,522 & 1,0 & 10,3 & 38,9 \\
\hline Peru & 2000 & 0,498 & 0,7 & 11,2 & 37,2 \\
\hline Venezuela & 1998 & 0,491 & 0,6 & 11,4 & 36,3 \\
\hline Costa Rica & 2000 & 0,465 & 1,4 & 13,1 & 34.8 \\
\hline Bolivia & 1999 & 0,447 & 13 & 132 & 320 \\
\hline China & 2001 & 0,447 & 1,8 & 13,7 & 33,1 \\
\hline Tailândia & 2000 & 0,432 & 2,5 & 15,6 & 33,8 \\
\hline Cingapura & 1998 & 0,425 & 1,9 & 14,4 & 32,8 \\
\hline Estados Unidos & 2000 & 0,408 & 1,9 & 16,1 & 29,9 \\
\hline Portugal & 1997 & 0,385 & 20 & 16.8 & 29.8 \\
\hline Nova Zelândia & 1997 & 0,362 & 2,2 & 17,8 & 27,8 \\
\hline Reino Unido & 1999 & 0,360 & 2,1 & 17,5 & 28,5 \\
\hline Itália & 2000 & 0,360 & 2,3 & 18,5 & 26,8 \\
\hline Austrália & 1994 & 0,352 & 2,0 & 17,9 & 25,4 \\
\hline Canadá & 1998 & 0,331 & 2,5 & 197 & 25,0 \\
\hline Suíca & 1992 & 0,331 & 2,6 & 19,6 & 25,2 \\
\hline França & 1995 & 0,327 & 2,8 & 19,8 & 25,1 \\
\hline Holanda & 1994 & 0,326 & 2,8 & 20,0 & 25,1 \\
\hline Espanha & 1990 & 0,325 & 2,8 & 20,1 & 25,2 \\
\hline Îndia & $1999-2000$ & 0,325 & 39 & 214 & 274 \\
\hline Coréia & 1998 & 0,316 & 2,9 & 21,5 & 22,5 \\
\hline Alemanha & 2000 & 0,283 & 3,2 & 22,2 & 22,1 \\
\hline República Tcheca & 1996 & 0,254 & 4,3 & 24,8 & 22,4 \\
\hline Bélgica & 1996 & 0,250 & 29 & 22,4 & 22,6 \\
\hline Suécia & 2000 & 0.250 & 36 & 231 & 222 \\
\hline Japão & 1993 & 0,249 & 4.8 & 24.8 & 21,7 \\
\hline Dinamarca & 1997 & 0,247 & 26 & 23,0 & 21,3 \\
\hline
\end{tabular}

Tabela 4: Indicadores de distribuição de renda e consumo.

Fonte DIEESE. Disponível em: <http://www.dieese.org.br/notatecnica/ notatecSMDR.pdf>. Acesso em 25 jan. 2009.

Sobre os dados constantes da tabela, o artigo traz o seguinte comentário:

Note-se que o Brasil apresenta um dos mais altos Índices de Gini entre os países selecionados $(0,591)$, bem como uma das maiores concentrações de renda na comparação entre a renda apropriada pelos $40 \%$ mais pobres e pelos $10 \%$ mais ricos. O Índice de Gini varia de zero (maior igualdade) a 1 (maior desigualdade) e é um dos indicadores mais utilizados nas análises sobre distribuição de renda. Essa concentração de renda brasileira é bem maior, inclusive, do que a de países mais 
pobres do Brasil, o que reforça a tese de que o aumento da renda, por si só, não é capaz de proporcionar uma distribuição mais justa.

Ora, diante de tamanha desigualdade na distribuição de renda, onde parcela considerável da população detém muito pouco da renda do país, como poderá o cidadão comum custear despesas desta natureza? E se puder, quão grande será o esforço para fazê-lo?

Uma das alternativas para o problema seria a Defensoria Pública da União, que atua perante os Tribunais Superiores e o Supremo Tribunal Federal. O órgão, instituído pela Lei Complementar n. 80 de 12 de janeiro de 1994, é bastante recente, se comparado com outros órgãos que exercem funções essenciais à Justiça, como as Defensorias Públicas dos Estados e o Ministério Público. Seu processo de estruturação teve início somente nesta década e ainda está em fase de desenvolvimento.

Um artigo publicado no website da Defensoria Pública da União <www.dpu.gov.br> , intitulado "Aos 18 anos, Defensoria Pública ainda é pequena", dá conta da falta de estruturação do órgão. A seguir, alguns trechos do referido artigo:

Dezoito anos após haver sido criada, com a Constituição de 1988, para promover a democratização da assistência judiciária à população carente, a Defensoria Pública está presente em apenas 39,7\% das 2.510 seções judiciárias existentes no País. (...).Na avaliação dos pesquisadores, embora pareça razoável, a distribuição de defensores não é equilibrada nos estados. Nas unidades da Federação com IDH considerado baixo, apenas o Acre e Paraíba prestam atendimento a todas as suas comarcas. No Maranhão, por exemplo, a Defensoria Pública cobre apenas 4,1\% do total de seções judiciárias, tendo mostrado assim o pior desempenho do País. (...).A pesquisa mostra ainda que, em 2004, as despesas referentes à Defensoria Pública representaram, em média, $0,24 \%$ das totais, verificando que a destinação aproximase bastante do limite tratado na Lei de Responsabilidade Fiscal. Os estados que menos investiram na instituição foram os da Paraíba, com 0,02\%, seguido do Amapá e Bahia, ambos com $0,04 \%$. Os que mais destinaram recursos foram os estados do Mato Grosso do Sul, com 0,56\%, e do Rio Grande do Sul e Roraima, ambos com $0,5 \%$. O diagnóstico, no entanto, mostra que, em comparação com os investimentos realizados em instituições como o Ministério Público e outras do Poder Judiciário, a Defensoria Pública participa, em média, com apenas com 3,3\% dos gastos totais dos estados. Nesse caso específico, Mato Grosso do Sul e Roraima são os que mais destinam recursos à Defensoria Pública em relação às verbas destinadas às outras 
instituições. O Rio Grande do Norte e a Paraíba, por outro lado, são os que repassam as menores fatias do orçamento à Defensoria, em relação ao Ministério Público e ao Poder Judiciário. Uma comparação feita no estudo revela que, para cada R\$ 1 investido na Defensoria Pública paraibana, R\$ 117,70 são investidos no Ministério Público e R\$ 334 no Poder Judiciário. A relação mais equilibrada ocorre no Rio de Janeiro.

Se levarmos em consideração a quantidade de processos distribuídos no Superior Tribunal de Justiça, é possível prever a grande dificuldade que a Defensoria Pública da União deverá enfrentar para assistir parte dos demandantes e demandados nesses processos, mesmo que seja uma quantidade pequena, se comparada com o número total de processos recebidos.

Diante do exposto e levando-se em consideração a extensão territorial do Brasil e os aspectos sócio-econômicos que fulminam a população, pode-se afirmar que o processo e o rito processual na forma em que se apresentam atualmente são, por si, um entrave significativo ao acesso do cidadão à Justiça. Pelas razões expostas, por muitas vezes, fica o cidadão afastado da jurisdição, notadamente em causas cujo valor seja baixo e não compense tamanhos gastos para receber uma resposta judicial favorável.

A informatização do Processo Judicial vem frontalmente ao encontro do problema, uma vez que os sistemas digitais de transmissão de dados quebram as barreiras de espaço e de tempo.

Uma petição, por exemplo, não precisará viajar na pasta do advogado ou pelo correio de uma cidade do interior do Brasil até o Superior Tribunal de Justiça. A sua transmissão por meio da Internet é instantânea e principalmente econômica. Como a Lei n. 11.419/2006 determina que os cartórios e serventias judiciais tenham equipamentos informatizados à disposição das partes e advogados, o cidadão ou seu representante poderá se dirigir ao fórum local para encaminhar a petição on line caso não tenha acesso a outros computadores. 
Da mesma forma, qualquer decisão proferida no STJ pode ser visualizada por meio da Internet no website do Tribunal, na opção consultas. Fica dispensado, desta forma, o excesso de esforço físico e financeiro para se obter um Diário da Justiça da União para fazer o acompanhamento do processo.

O Sistema Push, existente em muitos Tribunais do país e também no Superior Tribunal de Justiça permite às partes e advogados, desde que previamente cadastrados, receberem via $e$-mail os mais recentes andamentos nos processos em que litigam.

Tudo isso já é realidade no Superior Tribunal de Justiça.

A implementação plena do processo eletrônico, por meio da virtualização dos autos do processo, que deixará de existir em papel para se transformar em bits de computador, certamente significará o maior dos avanços em termos de acessibilidade.

Não haverá mais barreira de tempo, pois as transmissões e consultas são on line, 24 horas por dia e 7 dias por semana (salvo em caso de pane no sistema).

Da mesma forma, as dificuldades geográficas cairão, em sua maioria, por terra. Como o processo e todos os documentos são digitais, podem ser consultados nos termos da Lei n. $^{\circ}$ 11.419/2006, pelas partes e seus representantes de qualquer lugar do Brasil e do mundo, bastando para tanto ter a assinatura digital, ser vinculado ao respectivo processo como parte ou representante e ter disponível um computador conectado à Internet.

Desta forma, se alguém que more no Amazonas tiver que responder uma alegação feita pela parte adversa em um processo que tramita no Superior Tribunal de Justiça, basta acessar a Internet e consultar as alegações a serem refutadas, sem necessidade que qualquer outro ato referente a deslocamento.

No Superior Tribunal de Justiça não existem, ainda, sessões de julgamento on line, o que obriga o advogado que quiser sustentar oralmente comparecer em pessoa ao Tribunal para 
fazê-lo. Por meio da intranet do Tribunal, já é possível assistir algumas das sessões pelo computador, o que beneficia grandemente os servidores que trabalham na elaboração dos provimentos jurisdicionais, como os Assessores de Ministros. Todavia, as sustentações orais somente mediante a presença física do advogado na sessão de julgamento.

Em consonância com a informatização do processo digital, a regulamentação de sustentações orais por meio de vídeo-conferências traria grandes benefícios com base nos mesmos fundamentos explicitados.

\subsection{Celeridade Processual}

Dentre os julgamentos de grande notoriedade e repercussão realizados pelo Supremo Tribunal Federal, está o Inquérito 2.245. Nesse inquérito foi recebida a denúncia proposta pelo Exmo. Sr. Procurador-Geral da República contra um vasto número de autoridades da alta cúpula do governo, inclusive o ex-Ministro da Casa Civil da Presidência da República, além de lobistas e advogados, no caso conhecido como "mensalão".

Este evento, certamente marcará os anais da Corte Suprema, por significar a vitória do Estado Democrático de Direito contra a ardilosidade e poder dos poderosos e seus lobistas. Representa a solidificação do maior órgão do Poder Judiciário nacional e da Justiça brasileira, que conforme amplamente divulgado pela imprensa, mostrou-se impassível diante das pressões dos Poderes Executivo e Legislativo e julgou com segurança e grande celeridade, os indiciados como passíveis de ter uma ação penal tramitando contra si, mediante o recebimento da denúncia.

O evento marcará também a história do desenvolvimento e implementação da informatização do processo judicial, em benefício da Nação. Isso pois, o Relator do Inquérito, 
Exmo. Sr. Ministro Joaquim Barbosa, o primeiro negro a ocupar uma cadeira na Corte Suprema, fez uso dos insumos tecnológicos então disponíveis e determinou a digitalização integral do inquérito. As consequiências do ato de sua excelência são mencionadas pela Exma. Sra. Ministra Ellen Gracie, então Presidente do Supremo Tribunal Federal, em sua manifestação, perante o Plenário daquela Suprema Corte, quando da apreciação da denúncia no respectivo inquérito:

\begin{abstract}
Esses resultados só se fazem possíveis na medida e graças à segura condução do processo, empreendida pelo eminente Relator, Ministro Joaquim Barbosa. Sua Excelência fez também por utilizar recursos modernos de informática que facilitaram muito o seu trabalho, e também o nosso. Os autos foram, em seus cerca de cinqüenta e um volumes e mais de mil apensos, da primeira à última página, inteiramente digitalizados. Assim, foi possível que todos os Ministros tivessem acesso às peças do processo. Foi possível também aos ilustres defensores dos quarenta acusados o acesso simultâneo a este mesmo processo.

Não fosse por isso, somente a vista sucessiva dos autos teria consumido, no mínimo, por baixo, vinte meses, para que cada um dos acusados pudesse se manifestar nos autos. Não teríamos, portanto, chegado ao estágio atual.

O mesmo ganho de tempo será reproduzido na fase instrutória. Isso nos leva a crer que a utilização desses recursos, dessa tecnologia que serve à celeridade processual, deve prosseguir. Por isso mesmo, tivemos debates tão informados, neste Plenário, em todo o transcorrer das sessões de julgamento.
\end{abstract}

Diante do discurso da Exma. Sra. Ministra Presidente do STF, que ressalta com veemência os benefícios advindos do uso da tecnologia no processo judicial, dando especial destaque à celeridade no presente caso, desnecessário seria qualquer outra justificativa para demonstrar a viabilidade do processo judicial no que tange à economia de tempo no curso do processo.

Apesar disso, oportuno é destacar outros fatores relacionados à redução de tempo em virtude da utilização do processo eletrônico e dos demais insumos regulamentados pela Lei n. ${ }^{\circ} 11.419 / 06$. 
A extinção do deslocamento físico dos processos judiciais é fator de extrema relevância. Com os autos virtuais não haverá mais necessidade de o processo caminhar de "mão em mão" até o seu deslinde. As partes e os órgãos auxiliares da Justiça não precisarão mais se dirigir às secretarias para retirá-los e depois devolvê-los. Em caso de recurso, não haverá a necessidade de remessa física de um órgão jurisdicional para outro (muitas vezes em outras regiões do país) etc.

Extinguir-se-ão ainda, as chamadas vistas sucessivas, ou seja, a necessidade de cada uma das partes ter acesso aos autos de cada vez, em virtude do processo físico não poder estar “em dois lugares" ao mesmo tempo. No caso do inquérito do "mensalão", por exemplo, eram mais de 40 acusados e seriam intermináveis vistas sucessivas, se o processamento se desse no meio físico. No entanto, como o processo foi digitalizado, cada parte pôde ter acesso às informações simultaneamente, o que, segundo a Exma. Sra. Ministra Presidente, à época, gerou uma economia em termos temporais, de mais de 20 meses, em um único processo.

Outro aspecto de fundamental importância é a significativa diminuição das "atividades de secretaria”, baseadas na juntada de petições e documentos aos autos, dentre outros. Esse tipo de atividade exige a numeração de intermináveis páginas, confecção de diversas certidões etc. No processo eletrônico, este procedimento poderá ser feito diretamente pelos advogados, conforme preceitua o caput, do art. 10 da Lei da Informatização Judicial:

Art. 10. A distribuição da petição inicial e a juntada da contestação, dos recursos e das petições em geral, todos em formato digital, nos autos de processo eletrônico, podem ser feitas diretamente pelos advogados públicos e privados, sem necessidade da intervenção do cartório ou secretaria judicial, situação em que a autuação deverá se dar de forma automática, fornecendo-se recibo eletrônico de protocolo. 
Os servidores que ora executam tais atividades poderiam ser então realocados em outras áreas fundamentais para a instrução do processo e principalmente nas áreas relacionadas à pesquisa e produção de provimentos jurisdicionais. $\mathrm{O}$ procedimento conferiria mais efetividade ao Poder Judiciário, sem a necessidade de novas contratações e, conseqüentemente, de maior gasto de verba pública.

\subsection{Efetividade Processual}

O que é uma Justiça efetiva?

Caldas Aulete, em seu dicionário de língua portuguesa, define o termo efetivo como algo real, verdadeiro, que gera uma melhora efetiva.

A efetividade do processo judicial está ligada à concretização da resposta jurisdicional baseada nos princípios legais, éticos e morais estabelecidos pelo sistema legislativo e pela sociedade.

O Magistrado que conduz o processo é o principal responsável pela efetividade do processo judicial. É a sua atuação na análise das alegações das partes e das provas dos autos que resultará em uma decisão madura e condizente com a lei, a ética e a moral.

No atual estágio do desenvolvimento tecnológico, a inteligência artificial ainda é embrionária e não possui capacidade de substituir o julgador em suas decisões, apesar de já se discutir a sua utilização em sentenças programadas (MADALENA E OLIVEIRA, 2008). Desta forma, o papel da tecnologia no momento seria o de criar mecanismos para facilitar a atuação do Juiz no processo e não substituí-lo na sua função jurisdicional.

Por isso, diferentemente da atuação da tecnologia da informação e comunicação nas áreas da acessibilidade e celeridade processuais, onde ela exerce papel fundamental, em se tratando de efetividade processual seu papel é acessório. Isto não significa ser irrelevante ou 
dispensável. Ao contrário, o termo na realidade é utilizado com a premissa de colocar a atividade do "ser humano Juiz" em primeiro lugar, o que não quer dizer que os demais instrumentos e subsídios por ele utilizados não tenham razão de ser.

A tecnologia da informação e comunicação pode fornecer elementos capazes de auxiliar com grande eficiência o Magistrado no seu papel de julgar.

O primeiro elemento seria a otimização na análise do processo e nas pesquisas feitas pelo Juiz para definir a causa. Como exemplo hábil a justificar esta afirmação, tomar-se-á por base uma situação concreta, que será analisada sob os aspectos referentes ao processo físico e ao processo virtual.

Determinado Magistrado está apreciando um caso que se constitui em um processo de 40 volumes, cada um com 250 páginas. Está então o julgador diante de dez mil páginas de alegações e provas para chegar a uma decisão.

Por se tratar de um processo físico, a atividade de manuseio dos autos é extenuante, pois para sua análise o Magistrado deverá deslocar, abrir e fechar cada um dos 40 volumes uma grande quantidade de vezes.

A pesquisa de dados neste processo seria tarefa hercúlea, pois apesar do rito processual pré-definido, torna-se bastante difícil encontrar determinada prova ou documento, muitas vezes de uma única página, no meio dessas dez mil páginas.

O Magistrado deverá ainda ter a máxima cautela com a sua saúde, pois os autos por serem de "matéria orgânica papel", com provas e documentos antigos, poderão conter bactérias nocivas à saúde se esses tiverem ficado, por exemplo, expostos à umidade excessiva. Outra forma de proliferação de bactérias nos autos seria deixar uma simples gota de café cair sobre ele. Destaca-se ainda que o ser humano, ou vários seres humanos, que manuseiam o 
processo ao longo do tempo estão, durante esse período, em contato direto com o mesmo. As mãos tocam-no incessantemente e os olhos, nariz e boca estão bem próximos a ele.

Caso esse processo fosse eletrônico, existindo no meio digital e não físico, os problemas relatados não existiriam, o que facilitaria a atividade do julgador no exercício da tutela jurisdicional, bem como das partes e advogados.

Os esforços físicos para manusear os autos seriam nulos, já que todo o movimento para abertura e fechamento de autos, colocação dos mesmos e retirada da mesa seriam substituídos pelos movimentos do mouse e pela utilização do teclado e decorrentes das informações apresentadas no monitor do computador.

A pesquisa de informações nos autos seria facilitada mediante o uso das ferramentas de pesquisa existentes no meio digital, as quais utilizam "palavras-chave" para buscar determinado documento. Desta forma, para se encontrar um laudo pericial específico no processo, bastaria digitar "palavras-chave" capazes de identificá-lo, como por exemplo, “corpo de delito", e o computador por meio do software específico realizaria a busca com grande velocidade, sendo desnecessário revolver dez mil páginas para fazê-lo, como no caso mencionado.

Por fim, o organismo do Magistrado e de todos os demais que manuseariam os autos não teriam mais contato com materiais tão passíveis de absorção de umidade e proliferação de bactérias como o papel.

Outro aspecto relacionado à efetividade do processo está na segurança das informações contidas nos autos.

Por mais preparo e boa vontade que tenha um julgador e por mais facilitado que seja o seu trabalho por meio da tecnologia, esse somente poderá decidir com retidão e justiça, se as 
informações constantes dos autos forem fidedignas com a realidade, não tendo sido adulteradas por diversos meios de falsificação ou excluídas do processo.

Existem histórias no meio acadêmico forense que são contadas por professores em várias faculdades de direito aos alunos como casos pitorescos e, no mínimo, interessantes sobre o processo judicial.

Dentre essas histórias, uma das mais conhecidas é a do advogado que pediu para ver os autos de uma ação de cobrança em uma secretaria de vara e, quando o funcionário deixouo sozinho no balcão, ele retirou um cheque do processo, única prova do débito questionado e literalmente mastigou-o e depois o engoliu.

Se o caso descrito é uma "estória" ou uma "história", não se sabe. No entanto, situação como a descrita é plenamente passível de ocorrer. A retirada dos autos do respectivo órgão jurisdicional gera, por si só, a possibilidade de adulteração de documentos e provas uma vez que por mais que se considere uma parcela mínima, nem todos os advogados e partes estão de boa fé. É preciso considerar que em determinados processos, interesses de uma vida e grandes somas de dinheiro estão em jogo.

Ora, se na atualidade é notória a existência de falsificações de grande quilate e perfeição (ironicamente por meio do uso da tecnologia), até mesmo de papel moeda e documentos expedidos por órgãos públicos (identidade, carteira de habilitação etc), confeccionados em papel especial, com selos tridimensionais, entre outros; o que se dirá sobre a possibilidade de falsificar um laudo ou depoimento digitado ou datilografado ou uma simples assinatura?

Além de atos de cristalina má-fé como os mencionados, podem ocorrer situações imprevistas por culpa (nas modalidades imprudência, negligência ou imperícia) por parte do portador do processo em determinado momento que venha a impedir o julgamento do caso, 
além de outras situações de caso fortuito ou de força maior que resultem no mesmo deslinde. O extravio do processo ou sua deterioração por um incêndio são hipóteses razoáveis e plenamente possíveis de ocorrer. Se tais eventos ocorressem, os autos deveriam ser reconstituídos e o procedimento de reconstituição dos autos, previsto no Código de Processo Civil, quando possível é moroso e bastante complicado.

Em se tratando do processo virtual, tais situações se não impossíveis de ocorrer, serão ao menos bastante improváveis.

O processo eletrônico possui estrutura digital e todos os dados a ele referentes ficam “arquivados" em um (ou mais) servidor de armazenamento de dados. Magistrados, Órgãos Auxiliares da Justiça, Advogados e Partes terão acesso a ele por meio de cópia obtida por meio deste provedor, como se fosse um espelho do processo. Desta forma, torna-se bastante difícil a falsificação dos documentos, uma vez que esses estão arquivados digitalmente neste provedor. Seria inócuo a uma parte alterar a informação extraída de um processo digital armazenada em um provedor de armazenamento de dados, pois a informação alterada estará em dissonância com a que consta no provedor.

Os dados armazenados são geralmente criptografados, o que dificulta grandemente o seu acesso com o objetivo de promover alterações.

Sobre a segurança das informações transmitidas por meio da rede mundial de computadores, existem questionamentos feitos no tocante ao risco de receptação e alteração. No entanto, a utilização da criptografia e outros insumos de segurança como a certificação digital dificultam bastante tais artifícios.

Sobre o uso da criptografia como forma de garantir segurança às informações, destaca Benucci (2007, p. 91): 
De fato, a técnica computacional e a matemática permitiram o desenvolvimento de alogorítimos que dificultam sobremaneira a decodificação da mensagem criptografada, pois o esforço e o tempo necessários para se decifrar a mensagem seriam de tal ordem, que a criptografia pode ser considerado um meio seguro de se efetuar a comunicação.

Essa segurança proporcionada pelas técnicas criptográficas foi sensivelmente ampliada a partir da introdução, em 1976, do conceito de criptografia assimétrica, que torna possível a equiparação, para fins jurídicos, do ato praticado em meio eletrônico ao ato praticado com o uso da comunicação convencional, pois fornece os requisitos de segurança necessários para proporcionar validade jurídica, ou seja: a certeza de que o ato tem procedência daquele que afirma tê-lo produzido, garantindo, assim, a autoria, e também de que o conteúdo do ato não tenha sido alterado.

Deve ainda ser lembrado o fato de os bancos viabilizarem vários tipos de transações, envolvendo dinheiro por meio da Internet além de utilizarem massivamente formas de pagamento em meio eletrônico, como os cartões de débito e de crédito. E essa atividade está em franco crescimento e desenvolvimento. Se isto está ocorrendo, é porque a relação de "custo-benefício" através da utilização da Internet para transações comerciais é viável, sob pena de grandes instituições financeiras irem à falência. Essa afirmação é confirmada por notícia veiculada em 11/08/2008, pelo website do Jornal de Brasília <www.jornaldebrasilia.com.br>, que informa a divulgação do crescimento da utilização dos meios eletrônicos por diversas operações pelos bancos no Brasil:

O Banco Central confirmou hoje, em sua página da Internet (www.bcb.gov.br), que o uso de instrumentos eletrônicos de pagamento tem tido evolução contínua no país, e cresceu 53,4\% nos últimos cinco anos. A evolução foi de 9,4\% em 2007 , comparado a 2006.

A informação consta do Diagnóstico do Sistema de Pagamentos de Varejo - Adendo Estatístico 2007, que engloba todas as pesquisas realizadas pelo BC no período de 2002 a 2007. Para acessar o serviço basta acrescentar (.../htms/SPB/Diagnosticoadendo-2007.pdf) ao endereço eletrônico do banco.

A estatística considera todos os meios eletrônicos de pagamento de bloquetos de cobrança nos caixas de auto-atendimento, aí incluídas também as transferências de crédito, débitos em conta e movimentações por cartão de crédito e de débito.

O Adendo Estatístico 2007 comprova a tendência de redução do uso de cheques no país, com queda de 36,8\% de 2002 para cá. Em contrapartida, houve aceleração de $38 \%$ no uso e cartões de crédito e de $31,4 \%$ na utilização de cartões de débito.

Agência Brasil. 


\subsection{Outros aspectos relevantes a serem considerados no que se refere à viabilidade de implementação plena do processo eletrônico}

O Superior Tribunal de Justiça, assim como vários outros órgãos do Poder Judiciário, sofre hoje com a falta de espaço físico.

Esse tipo de problema se torna evidente se for levado em consideração o crescimento processual ao longo dos anos. Em termos literais, não há mais espaço no Tribunal para acomodar tantos processos. Para se ter uma idéia, cada Gabinete de Ministro hoje ocupa uma área que é o dobro do tamanho concebido originalmente e, mesmo assim, vários Gabinetes possuem depósitos no subsolo do Tribunal para guardar processos.

Quando um processo é extinto, mediante o trânsito em julgado da decisão, ele deve ser necessariamente arquivado, ou seja, guardado em algum lugar por prazo indefinido. Não pode o processo ser, por exemplo, incinerado ou simplesmente descartado. Desta forma, apesar do litígio oriundo do processo ter sido solucionado, o problema decorrente do espaço que esse processo deverá ocupar indefinidamente persiste.

No Superior Tribunal de Justiça, a Seção de Documentos Judiciários é a responsável pela guarda e conservação dos processos judiciais. Segundo informação obtida na intranet do STJ, a Seção de Documentos Judiciários (SEDJU) se responsabiliza pela guarda e conservação dos processo do extinto Tribunal Federal de Recursos, cujo acervo resulta em 55.000 processos. O acervo do STJ arquivado no Tribunal pela SEDJU em janeiro de 2009 resulta em 36.000 processos, pois somente ficam arquivados na Corte os processos que lá se iniciaram, chamados de competência originária (ações penais originárias por exemplo). Os demais processos julgados pelo STJ, chegam até ele na forma de recurso e, após o trânsito em 
julgado são remetidos à justiça de origem para serem arquivados ou ao Supremo Tribunal Federal, se houver algum outro recurso pendente de julgamento.

O processo virtual tornará desnecessário o arquivamento na forma em que ocorre hoje, uma vez que esse se dará por meio digital, em provedores com enorme capacidade de armazenamento. Os processos físicos que avolumam os Gabinetes e as Secretarias também desaparecerão e o espaço poderá ser melhor aproveitado.

Por fim, em um mundo cada vez mais voltado para a questão ambiental, em que se busca a sustentabilidade como forma de garantir a permanência da vida na Terra, os impactos ambientais que a desnecessidade do uso do papel, plástico, metal em processos judiciais, e demais insumos que tem esgotado a natureza, são altamente desejáveis. 

ESPECIAIS FEDERAIS DO ESTADO DE SANTA CATARINA

O website da Justiça Federal de Santa Catarina (http://www.jfsc.gov.br), que já utiliza os elementos da informatização dos processos judiciais incluindo o processo eletrônico, disponibiliza aos usuários em público em geral o "Curso Rápido de Introdução ao Sistema de Processo Eletrônico da Justiça Federal”.

O curso é baseado em vários módulos, transmitidos por meio de vídeo-aula no próprio site. Nesses módulos o sistema é apresentado, existindo ainda explicações detalhadas sobre o acesso ao sistema, cadastro de advogados, ajuizamento de ações, movimentações processuais e prazos para usuários internos e externos.

O primeiro módulo apresenta, em termos gerais, o sistema de informatização judicial utilizado pelos Juizados Especiais Federais de Santa Catarina, com suas especificações, peculiaridades e vantagens.

As figuras a seguir foram retiradas da vídeo-aula disponível no website da Justiça Federal de Santa Catarina (http://www.jfsc.gov.br), referentes ao primeiro módulo: apresentação do sistema :

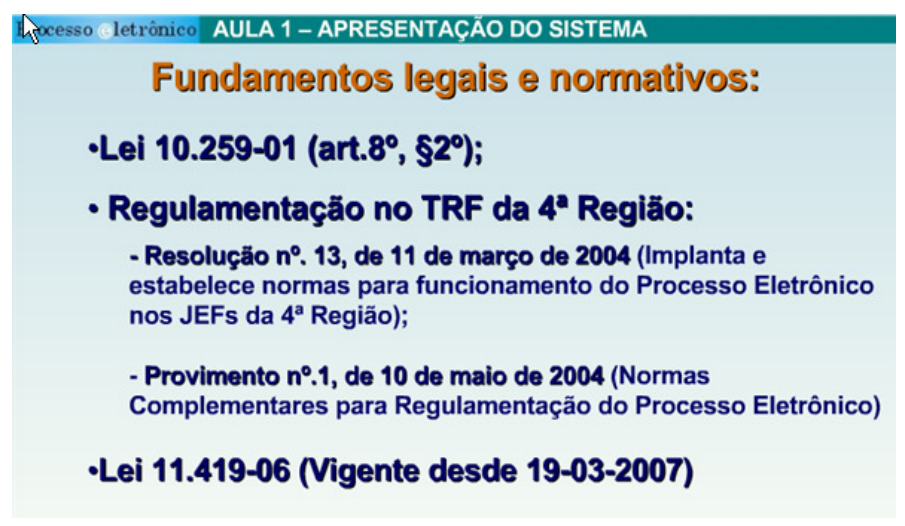

Figura 6: Fundamentos Legais e Normativos para a implementação do sistema de informatização do processo judicial.

Fonte: Justiça Federal de Santa Catarina. Disponível em: <http://ead.jfsc.gov.br/p24986723/>. Acesso em 25 jan. 2009 
Implantaçäo do sistema:

-Instalaçăo: Julho de 2003;

-Ampliação gradativa das competências e matérias com tramitaçäo no sistema;

-Instalação gradativa nas subseçőes judiciárias da 4' Regiäo;

-31 de março de 2007: Instalaçäo definitiva em todos os Juizados Especiais Federais da $4^{a}$ Regiăo.

Figura 7: Implementação do sistema de informatização do processo judicial.

Fonte: Justiça Federal de Santa Catarina. Disponível em: $<$ http://ead.jfsc.gov.br/p24986723/>. Acesso em 25 jan. 2009.

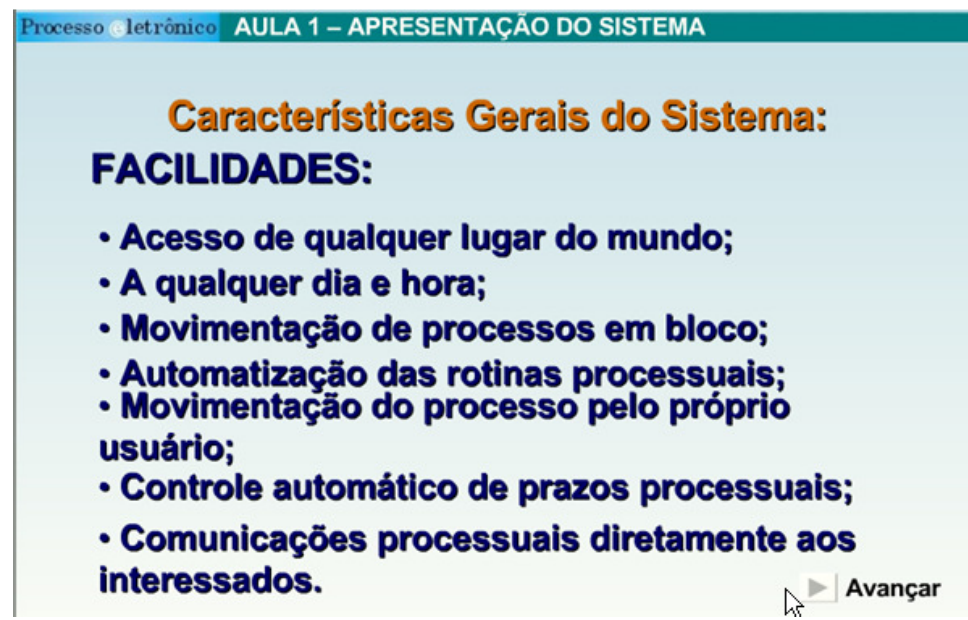

Figura 8: Características gerais do sistema de informatização do processo judicial. Fonte: Justiça Federal de Santa Catarina. Disponível em: <http://ead.jfsc.gov.br/p24986723/>. Acesso em 25 jan. 2009.

\section{Ã̧ocesso cletrônico AULA 1 - APRESENTAÇẢO DO SISTEMA \\ Características Gerais do Sistema:}

\section{SEGURANÇA:}

- Sítio com criptografia de dados;

- Sistema de protocolo de processos e documentos com sequiência de caracteres identificável;

- Sistemas de backup e replicação de dados (espelhamento) estadual e regional;

- Logins e senhas rastreáveis;

Figura 9: Características gerais do sistema de informatização do processo judicial (continuação...).

Fonte: Justiça Federal de Santa Catarina. Disponível em: $<$ http://ead.jfsc.gov.br/p24986723/>. Acesso em 25 jan. 2009. 


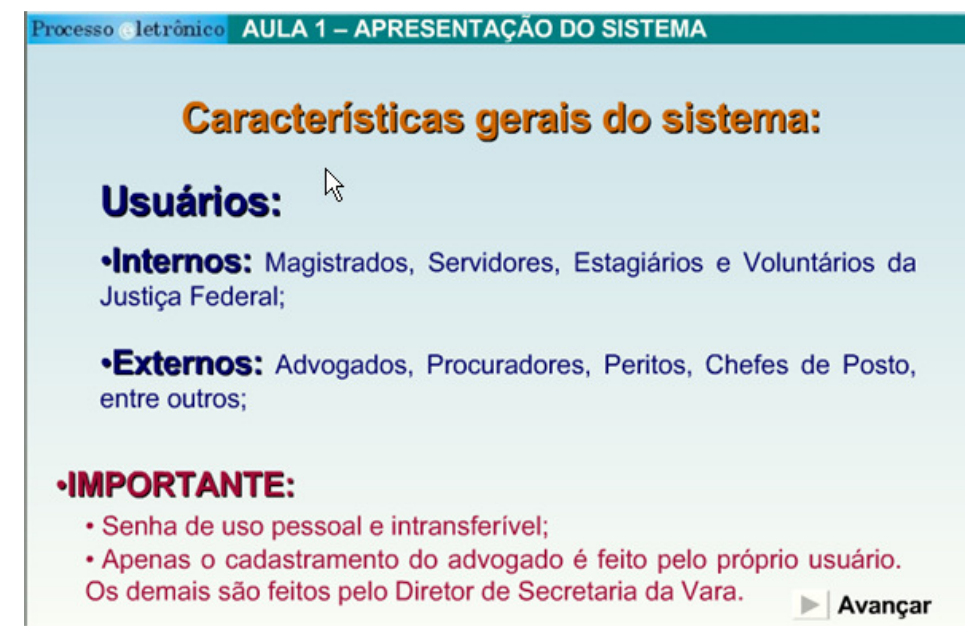

Figura 10: Características gerais do sistema de informatização do processo judicial (continuação...).

Fonte: Justiça Federal de Santa Catarina. Disponível em: <http://ead.jfsc.gov.br/p24986723/>. Acesso em 25 jan. 2009.

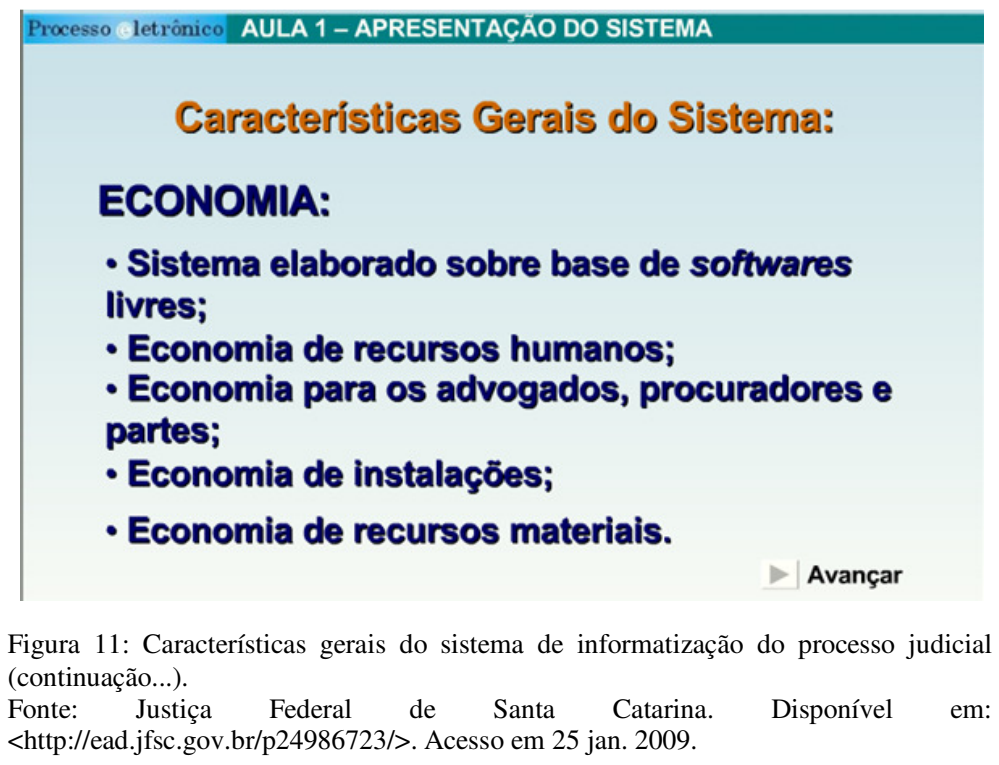

Inovou a Justiça Federal de Santa Catarina com o serviço ora disponibilizado. Como já mencionado, a inclusão digital possui três pilares: tecnologia da informação e comunicação, renda e educação.

O curso oferecido no site dos Juizados Federais de Santa Catarina, agrega conhecimentos fundamentais à utilização do sistema, de forma rápida e econômica. $\mathrm{O}$ curso 
pode ser feito de qualquer lugar do mundo e sem qualquer ônus, bastando apenas que o interessado tenha a sua disposição um computador com acesso à internet.

Acredita-se que a Justiça Federal de Santa Catarina, com tal iniciativa está patrocinando de forma direta a terceira vertente da inclusão digital relacionada à informatização dos processos judiciais - a educação voltada à operação do sistema. 


\section{CONCLUSÃO}

A necessidade do ordenamento das condutas humanas surgiu em razão do fato do homem ser um ser social e, por isso, viver em sociedade. Dos relacionamentos resultantes surgiram conflitos de interesse, que se resistidos por um dos conflitantes ou por ambos acarretavam litígios. O ordenamento das condutas dos homens fez-se necessário na medida em que os litígios tinham que ser solucionados de alguma forma.

Os meios de resolução dos litígios evoluíram com o desenvolvimento do homem através dos tempos, migrando da auto-tutela, que se constituía no "fazer justiça com as próprias mãos", para a tutela jurisdicional do Estado, onde o próprio Estado, através do Poder Judiciário, passou a solucionar os litígios, através da jurisdição ou ato de "se dizer o direito".

O Poder Judiciário Brasileiro exerce o poder jurisdicional por meio de determinações normativas oriundas do processo legislativo regular, regulamentos expedidos por órgãos específicos, dentre outros. É o que se chama de "Direito Positivo". Para tanto, faz uso do processo judicial, que é um conjunto de documentos relativos ao caso analisado, na sua maioria em papel, unidos na forma de uma "pasta"de documentos, e que seguem determinados ritos constantes da legislação processual pátria, de acordo com a sua natureza.

Com o crescimento da demanda pelo Poder Judiciário Brasileiro como um todo, e também no Superior Tribunal de Justiça, os órgãos jurisdicionais tem enfrentado dificuldades para garantir o acesso ao cidadão brasileiro "às suas portas", bem como para solucionar com celeridade e efetividade os casos que lhes são propostos.

A informatização do processo judicial vai em direção à solução desses problemas com o objetivo de, através do uso das tecnologias da informação e da comunicação, otimizar o 
trâmite processual no que se refere aos aspectos da acessibilidade, celeridade e efetividade processual.

Com base no disposto no art. $1^{\circ}$, caput, da Lei n. $^{\circ} 11.419 / 2006$, pode o processo judicial eletrônico ser conceituado como o processo judicial que utiliza o meio eletrônico para a sua tramitação, comunicação de atos e transmissão de peças processuais.

A informatização do processo judicial, no entanto, vem ocorrendo desde que o Poder Judiciário recebeu seus primeiros computadores. A partir de então, algumas tarefas rotineiras como elaboração de documentos que exigiam modelos pré-definidos já passaram a ser realizadas com a utilização do computador.

A legislação pátria, por seu turno, procurou acompanhar os avanços da tecnologia, regulamentando a sua utilização em todo o Poder Público, surgindo daí o conceito de Governo Eletrônico. No que se refere ao Poder Judiciário, várias leis surgiram para possibilitar a utilização nesse de determinados meios eletrônicos e outros insumos tecnológicos, como por exemplo, a Lei n. ${ }^{\circ} 9.800 / 99$ (Lei do Fax) e a Lei n. ${ }^{\circ} 11.419 / 2006$, já mencionada, que significou o maior avanço até o momento em direção ao uso das tecnologias da informação e da comunicação no Poder Judiciário.

A Lei n. ${ }^{\circ}$ 11.419/2006 inova ao regulamentar a implementação de insumos tecnológicos como a petição eletrônica, o diário de justiça eletrônico e o processo eletrônico. Por meio dessa norma, será legalmente possível a transição dos autos "de papel” para os autos digitais, onde a grafia e tinta serão substituídas por bits de computador. 
A implementação da lei de informatização do processo judicial exigirá mudanças tanto no Poder Judiciário e no STJ, quanto na sociedade brasileira, onde gastos expressivos já estão ocorrendo para esse fim e paradigmas deverão ser quebrados.

Em todo o Poder Judiciário, serão necessários uma série de insumos tecnológicos que envolvem hardwares, software e a implementação física e normativa de outros insumos que dependem dos dois primeiros para existir (assinatura digital, a petição eletrônica, o diário de justiça eletrônico ou on line).

O Superior Tribunal de Justiça possui regulamentação tanto para a petição eletrônica (Resoluções n. ${ }^{\circ} 2$ e n. ${ }^{\circ} 9$ de 2007) como para o diário da justiça eletrônico (Resolução n. ${ }^{\circ} 8$ de 2007). Esses mecanismos já estão implementados no Tribunal. A assinatura digital, da mesma forma já se encontra amplamente regulamentada em território nacional.

Os benefícios da informatização do processo judicial dizem respeito necessariamente à acessibilidade, celeridade e efetividade processual. Uma vez que a concepção de justiça está diretamente relacionada a esses aspectos.

No que toca à acessibilidade, deve ser registrado que não obstante o Princípio da Inafastabilidade da Jurisdição (art. $5^{\circ}, \mathrm{XXXV}$ ), segundo o qual a lei não poderá excluir da apreciação do Poder Judiciário lesão ou ameaça de lesão a direito; outros fatores acabam por dificultar o acesso do cidadão à Justiça. A vastidão territorial do Brasil; o nosso sistema jurisdicional que se utiliza de infindáveis recursos de uma instância para outra - sendo que muitas vezes os órgãos jurisdicionais ficam em cidades muito distantes; e a má distribuição de renda do país, onde "poucos têm muito e muitos quase nada" e que torna o Brasil um país rico mas de "poucos ricos e muitos pobres" acabam por dificultar e até mesmo impedir o acesso de 
muitos cidadãos à Justiça, notadamente pela falta de recursos financeiros para suportar o ônus do processo, onde se incluem viagens interestaduais, estadia, alimentação etc.

A informatização do processo judicial, em virtude de sua natureza digital, quebra as barreiras de tempo e espaço impostas pelo processo em meio físico. Para se ter acesso a determinada alegação feita pela parte adversa no Superior Tribunal de Justiça, um morador de uma pequena cidade no Rio Grande do Sul, ou seu advogado, não precisarão percorrer mais de $1.500 \mathrm{~km}$ até o STJ. Basta acessar a internet e para ter acesso às mencionadas alegações. Tal possibilidade resultará em economia significativa, notadamente sob o aspecto financeiro.

Em termos de celeridade, o processo judicial informatizado trará inúmeros benefícios. Como a limitação de tempo e espaço é quebrada mediante a utilização do meio digital, o processo pode estar "em vários lugares" ao mesmo tempo, ou seja, ter várias pessoas acessando suas informações em um mesmo instante. A partir de então, não haverá mais razão de ser para as "vistas sucessivas", procedimento em que cada parte do processo deve ter acesso aos autos sucessivamente, por indefinidas vezes. Em um processo com muitos réus, por exemplo, as vistas sucessivas podem retardar enormemente a resposta judicial. No Inquérito Judicial n. ${ }^{\circ} 2.245$ que tramitou junto ao Supremo Tribunal Federal, conhecido como “caso do mensalão", o Exmo. Sr. Ministro Joaquim Barbosa, gerou uma economia de mais de vinte meses segundo informado pelo próprio STF, no curso do processo por determinar a digitalização dos autos e entregá-los em meio eletrônico para cada uma das partes, evitando assim a necessidade de vistas sucessivas. Esse fato, bem como os benefícios oriundos da informatização do processo judicial, ficaram expressamente consignados no recebimento da denúncia pelo Tribunal Pleno nos autos desse inquérito, através das palavras então Presidente 
da Corte Suprema, Exma. Sra. Ministra Ellen Gracie e que se encontram consignadas nesse trabalho.

No que se refere à efetividade processual, pode-se afirmar que a informatização do processo judicial facilitará o manuseio e a pesquisa no processo, além de, por meio do uso de diversos recursos como a criptografia assimétrica, aumentar o nível de segurança do processo e, conseqüentemente reduzir as possibilidades de alteração e subtração de documentos e provas. A diminuição de atividades de secretaria, como a juntada de documentos por exemplo, será uma realidade e acarretará uma realocação de pessoas para suprir áreas nos Tribunais que demandam mais pessoas, sem a necessidade de novas contratações.

Além da otimização do processo judicial quanto à acessibilidade, celeridade e efetividade processual; a virtualização do processo acarretará uma redução significativa no uso de papel, tinta, metal, plásticos, entre outros elementos, o que em muito contribuirá para a redução do impacto ambiental no planeta e colocará o Superior Tribunal de Justiça e todo o Poder Judiciário no caminho da auto-sustentabilidade.

Outro aspecto a ser ressaltado é o ganho de espaço físico nos órgãos judiciais, uma vez que o processo deixará de existir em papel, sendo armazenado em meio eletrônico. Processos com mais de 200 volumes, se tornarão bits de computador e migrarão para servidores de armazenamento de dados com grande capacidade, liberando muito espaço.

Por fim, a sociedade brasileira deve possuir condições de absorver tamanha mudança e ao mesmo tempo usufruir os seus benefícios. Para que isso possa ocorrer, um fator será imprescindível: Inclusão Digital. 
A inclusão digital pode ser conceituada como o esforço conjunto dos órgãos governamentais e da sociedade civil para que ambas as camadas da sociedade possam ter acesso e se beneficiarem das inovações tecnológicas. Três são os pilares da inclusão digital: tecnologias da informação e comunicação; renda e educação.

A Administração Pública tem se voltado cada vez mais para a necessidade de informatização da sociedade brasileira por meio da inclusão digital. Através de uma série de programas, busca aquela estimular e facilitar o acesso do cidadão brasileiro às mais diversas tecnologias, principalmente o computador e a internet.

Os resultados desses programas são refletidos em várias pesquisas realizadas, sobre o acesso do brasileiro ao computador e a internet (principais insumos para a utilização dos serviços resultantes da informatização do processo judicial), que demonstram o aumento crescente, mesmo nas camadas da população com menor renda.

Com base nisso, pode-se concluir que a sociedade brasileira, se ainda não está preparada, caminha para a preparação, em termos de inclusão digital, necessária ao usufruto dos benefícios trazidos pela informatização do processo judicial.

A virtualização do processo, com base na Lei n. ${ }^{\circ} 11.419 / 2006$, já tem sido utilizada em sua forma plena em alguns órgãos judiciais do país, dentre os quais podem ser destacados os Juizados Especiais Federais de Santa Catarina. A experiência nesses Juizados tem se demonstrado bastante positiva.

Não deve a informatização do processo judicial no Brasil ser considerada a solução para os problemas da sociedade brasileira no que se refere à justiça, pois os conflitos de interesse que acarretam o litígio sempre ocorrerão, tendo em vista a própria natureza social do ser humano, e o força a se relacionar com seus semelhantes e a discordar deles muitas vezes. Apesar de não trazer, por si, a justiça plena, a informatização poderá aumentar o acesso do 
cidadão da justiça, tornar mais célere a condução do processo judicial e mais efetivas as respostas jurisdicionais, por meio das quais se busca o verdadeiro ideal de justiça. 
ALMEIDA FILHO, José Carlos de Araújo. Processo Eletrônico e Teoria Geral do Processo Eletrônico: A Informatização Judicial no Brasil. Rio de Janeiro. Forense, 2007.

Dados Sobre a Informatização Judicial no Brasil. 2006. Disponível em <http://www.processoeletronico.com.br>. Acesso em 25 jan. 2009.

ALEXANDRINO, Marcelo e PAULO, Vicente. Direito Administrativo Descomplicado. 16. ed. São Paulo. Método, 2008.

BENUCCI, Renato Luís. A Tecnologia Aplicada ao Processo Judicial. Campinas. Millennium, 2007.

Demócrito Filho, Reinaldo; BLUM, Renato Ópice; VOLPI, Marcelo Marlon e outros autores. Direito da Informática: Temas Polêmicos. São Paulo. Edipro, 2002.

BRASIL. Constituição da República Federativa do Brasil de 1998, atualizada até a Emenda Constitucional n. ${ }^{\circ} 57$ de 18 de dezembro de 2008. Disponível em: $<$ http://www.planalto.gov.br/ccivil_03/Constituicao/Constituiçao.htm>. Acesso em 25 jan. 2009.

BRASIL. Decreto n. ${ }^{\circ}$ 3.872, de 18 de julho de 2001. Disponível em: <http://www.planalto.gov.br/ccivil_03/decreto/2001/D3872.htm>. Acesso em 25 jan. 2009.

BRASIL. Decreto n. ${ }^{\circ}$ 6.605, de 14 de outubro de 2008. Disponível em: <http://www.planalto.gov.br/ccivil_03/_Ato2007-2010/2008/Decreto/D6605.htm>. Acesso em 25 jan. 2009.

BRASIL. Decreto-Lei n. ${ }^{\circ}$ 3.689, de 03 de outubro de 1941. Disponível em: <http://www.planalto.gov.br/ccivil_03/Decreto-Lei/Del3689.htm>. Acesso em 25 jan. 2009.

BRASIL. Decreto-Lei n. ${ }^{\circ}$ 5.869, de 17 de janeiro de 1973. Disponível em: <http://www.planalto.gov.br/ccivil_03/LEIS/L5869.htm>. Acesso em 25 jan. 2009.

BRASIL. Emenda Constitucional n. ${ }^{\circ}$ 32, de 11 de setembro de 2001. Disponível em: $<$ http://www.planalto.gov.br/ccivil_03/Constituicao/Emendas/Emc/emc32.htm>. Acesso em 25 jan. 2009.

BRASIL. Lei.$^{\circ} 8.245$, de 18 de outubro de 1991. Disponível em: <http://www.planalto.gov.br/ccivil_03/Leis/L8245.htm>. Acesso em 25 jan. 2009.

BRASIL. Lei n. ${ }^{\circ}$ 9.800, de 26 de maio de 1999. Disponível em: <http://www.planalto.gov.br/ccivil_03/Leis/L9800.htm>. Acesso em 25 jan. 2009. 
BRASIL. Lei n. ${ }^{\circ} 10.259$, de 12 de julho de 2001. Disponível em: <http://www.planalto.gov.br/ccivil_03/Leis/LEIS_2001/L10259.htm>. Acesso em 25 jan. 2009.

BRASIL. Lei n. ${ }^{\circ} 10.358$, de 27 de dezembro de 2001. Disponível em: <http://www.planalto.gov.br/ccivil_03/Leis/LEIS_2001/L10358.htm>. Acesso em 25 jan. 2009.

BRASIL. Lei n. ${ }^{\circ} 10.406$, de 10 de janeiro de 2002. Disponível em: <http://www.planalto.gov.br/ccivil_03/LEIS/2002/L10406.htm>. Acesso em 25 de jan. 2009.

BRASIL. Lei n. ${ }^{\circ} 11.280$, de 16 de fevereiro de 2006. Disponível em: <http://www.planalto.gov.br/ccivil_03/_Ato2004-2006/2006/Lei/L11280.htm>. Acesso em 25 jan. 2009.

BRASIL. Lei n. ${ }^{\circ} 11.341$, de 07 de agosto de 2006. Disponível em: <http://www.planalto.gov.br/ccivil_03/_Ato2004-2006/2006/Lei/L11341.htm>. Acesso em 25 jan. 2009.

BRASIL. Lei n. ${ }^{\circ} 11.419$, de 19 de dezembro de 2006. Disponível em: <http://www.planalto.gov.br/ccivil_03/_Ato2004-2006/2006/Lei/L11419.htm>. Acesso em 25 jan. 2009.

BRASIL. Medida Provisória n. ${ }^{\circ} 2.200-2$ de 24 de agosto de 2001. Disponível em: <http://www.planalto.gov.br/ccivil_03/MPV/Antigas_2001/2200-2.htm>. Acesso em 25 jan. 2009.

BRASIL. Programas de Inclusão Digital. Disponível em: <http://www.inclusaodigital.gov.br/inclusao/outros-programas>. Acesso em 25 jan. 2009.

BRASIL. Projeto de Lei n. ${ }^{\circ}$ 5.828, apresentado em 04/12/2001, e alterações. Disponível em: $<$ http://www2.camara.gov.br/proposicoes/loadFrame.html?link=http:\%20//www.camara.gov. br/internet/sileg/prop_lista.asp?fMode $=1 \&$ btnPesquisar $=O K \& A n o=2001 \&$ Numero $=5828 \&$ si gla=PL>. Acesso em 25 jan. 2009.

BRASIL. Projeto de Lei da Câmara n. ${ }^{\circ}$ 71, apresentado em 20/06/2002, e alterações. Disponível em: <http://www.senado.gov.br/sf/atividade/materia/detalhes. asp?p_cod_mate=50764>. Acesso em 25 jan. 2009.

BRASIL. Sociedade da Informação no Brasil: Livro Verde. Organizado por Tadeo Takahashi. Brasília. Ministério da Ciência e Tecnologia, 2000.

CASTELLS, Manuel. A Sociedade em Rede - Era da Informação, Economia, Sociedade e Cultura. Vol. I. São Paulo. Paz e Terra, 1999.

CENTRO DE ESTUDOS SOBRE AS TECNOLOGIAS DA INFORMAÇÃO E DA COMUNICAÇÃ̃. Pesquisa sobre o uso das Tecnologias da Informação e da Comunicação 
no Brasil. 2008. Disponível em: <http://www.cetic.br/ usuarios/tic/2007/index.htm>. Acesso em 25 jan. 2009.

CENTRO DE ESTUDOS SOBRE AS TECNOLOGIAS DA INFORMAÇÃO E DA COMUNICAÇÃO. Pesquisa sobre o do Governo Eletrônico pelo cidadão Brasileiro. 2008. Disponível em: < http://www.cetic.br/usuarios/tic/2007/destaques-governo-eletronico-tic2007.pdf>. Acesso em 25 jan. 2009.

CINTRA, Antônio Carlos de Araújo, GRINOVER, Ada Pelegrini e DINAMARCO, Cândido Rangel. Teoria Geral do Processo. 13ª ed. São Paulo. Malheiros Editores, 1997.

CONSELHO NACIONAL DE JUSTIÇA. Resolução n. ${ }^{\circ} 65$ de 16 de dezembro de 2008. Disponível em: <http://www.cnj.jus.br/images/stories/docs_cnj/resolucao/ rescnj_65.pdf>. Acesso em 25 jan. 2009.

DEFENSORIA PÚBLICA DA UNIÃO. Aos 18 anos, Defensoria ainda é pequena. 2006. Disponível em: < http://www.dpu.gov.br/dpu_midia/2006/dezembro/rls121206 commercio .htm>. Acesso em 25 jan. 2009.

DEZEN JÚNIOR, Gabriel. Curso Completo de Direito Constitucional. Vol. I. 4. ed. Brasília. Vestcon, 2003.

DIEESE. Salário Mínimo e Distribuição de Renda. 1995. Disponível em: < http:// www.dieese.org.br/notatecnica/notatecSMDR.pdf>. Acesso em 25 jan. 2009.

DI PIETRO, Maria Sylvia Zanella. Direito Administrativo. 21. ed. São Paulo. Atlas, 2008.

FERRER, Florência; SANTOS, Paula (Coordenadores). E-goverment: o Governo Eletrônico no Brasil. São Paulo. Saraiva, 2004.

GOLEMAN, Daniel. Inteligência Emocional, a Teoria revolucionária que redefine o que é ser inteligente. Rio de Janeiro. Objetiva, 2001.

GOIS JÚNIOR, José Caldas. O Direito na Era das Redes: A Liberdade e o Delito no Ciberespaço. São Paulo. Edipro, 2002.

JAMIL, George Leal. Repensando a TI na Empresa Moderna, atualizando a Gestão com a Tecnologia da Informação. Rio de Janeiro. Excel Books, 2001.

JORNAL DE BRASÍLIA. Banco Central confirma crescimento de serviços eletrônicos na rede bancária. 11/08/2008. Disponível em: < http://www.jornalde brasilia.com.br/portal/noticia.php?IdNoticia=66993>. Acesso em 25 jan. 2009.

LENZA, Pedro. Direito Constitucional Esquematizado. 8. ed. São Paulo. Método, 2005.

LOSANO, Mário. G. Os Grandes Sistemas Jurídicos. Lisboa. Presença, 1979. 
MADALENA, Pedro e OLIVEIRA, Álvaro Borges de. Organização e Informática no Poder Judiciário: Sentenças Programadas em Processo Virtual. 2. ed. Curitiba. Juruá, 2008.

MATIAS-PEREIRA, José. Manual de Metodologia da Pesquisa Científica. São Paulo. Atlas, 2007.

MONTESQUIEU, Charles Louis de. Do Espírito das Leis. 1. ed. São Paulo. Edipro, 2003.

NUNES, Elpídio Donizetti. Curso Didático de Direito Processual Civil. 4. ed. Belo Horizonte. Del Rey, 2003.

PARENTONI, Leonardo Neto. Documento Eletrônico: Aplicação e Interpretação pelo Poder Judiciário. Curitiba. Juruá, 2007.

PASA, Eduardo César. O Uso de Documentos Eletrônicos na Contabilidade. Revista de Contabilidade \& Finanças. v. 14. n. 25. São Paulo. FEAUSP.

REALE, Miguel. Filosofia do Direito. 19ª ed. $3^{\text {a }}$ tiragem .São Paulo. Saraiva, 2002.

REINALDO FILHO, Demócrito. A informatização do Processo Judicial da Lei do Fax à Lei n. 11.419/06. Uma breve retrospectiva legislativa. 2007. Disponível em: $<$ http://jus2.uol.com.br/doutrina/texto.asp?id=9399>. Acesso em 25 jan.2007.

ROBERTS, J.M. O Livro de Ouro da História do Mundo: da Pré-História à Idade Contemporânea. 12. ed. Rio de Janeiro. Ediouro, 2003.

ROVER, Aires José; KAMINSKI, Omar; VOLPI, Marlon Marcelo; MONTEIRO, Cláudia Sevilha e outros autores. Direito e Informática. São Paulo. Manole, 2004.

ROVER, Aires José. Informática no Direito: Introdução aos Sistemas Especialistas Legais. 1. ed. Curitiba. Juruá, 2001.

SANTOS, André Alencar dos. Informática Descomplicada. Brasília. Vestcon, 2005.

SILVA FILHO, Antônio Mendes da. Os três pilares da inclusão digital. Revista Espaço Acadêmico. Ano III, Número 24, Maio de 2003. Disponível em $<$ http://www.espacoacademico.com.br/024/24amsf.htm>. Acesso em 25 jan. 2009.

SUPERIOR TRIBUNAL DE JUSTIÇA. Boletim Estatístico: Ano 2007. Disponível em $<$ http://www.stj.jus.br/boletimestatistico/Relatorio2007/completo.pdf $>$. Acesso em 25 jan. 2007.

SUPERIOR TRIBUNAL DE JUSTIÇA. Boletim Estatístico: Ano 2008. Disponível em $<$ http://www.stj.jus.br/webstj/Processo/Boletim/verpagina.asp?vPag=0\&vSeq=12> . Acesso em 25 jan. 2007. 
SUPERIOR TRIBUNAL DE JUSTIÇA. Resolução n. ${ }^{\circ} 2$ de 24 de abril de 2007. Disponível em: <http://bdjur.stj.gov.br/jspui/bitstream/2011/9318/1/Res_2_2007.pdf>. Acesso em 25 jan. 2009.

SUPERIOR TRIBUNAL DE JUSTIÇA. Resolução n. 8 de 20 de setembro de 2007. Disponível em: <http://bdjur.stj.gov.br/jspui/bitstream/2011/9971/1/Res_8_2007_PRE. pdf>. Acesso em 25 jan. 2009.

SUPERIOR TRIBUNAL DE JUSTIÇA. Resolução n. ${ }^{\circ} 9$ de 05 de novembro de 2007. Disponível em: <http://bdjur.stj.gov.br/jspui/bitstream/2011/10179/1/Res_9_ 2007_PRE.pdf>. Acesso em 25 jan. 2009.

SUPERIOR TRIBUNAL DE JUSTIÇA. Seção de Documentos Judiciários. Disponível somente para quem tem acesso à Intranet do STJ em: $<$ https://intrasec.stj.gov.br/SGI/jsps/main.jsp?imInTab=CONHAG\&imInTabPai=ARQGER\#s edoju>. Acesso em jan. 2009.

SUPREMO TRIBUNAL FEDERAL. Inquérito 2.245. 2008. Disponível em: < http: //www.stf.jus.br/imprensa/pdf/tramiteAP.pdf>. Acesso em 25 jan.2009.

TAKAHASHI, Tadeo. Rumo à Sociedade da Informação: Situação Atual, Desafios e Perspectivas para o Brasil. 2002. Disponível em <http://www.cgee.org.br /arquivos/pro0201.pdf>. Acesso em 25 jan. 2009.

THEODORO JÚNIOR, Humberto. Curso de Direito Processual Civil. v. 1. 36 a ed. Rio de Janeiro. Forense, 2001.

Vadmecum Acadêmico de Direito. 4. ed. Organizado por Joyce Angher. São Paulo, 2007. 